Flávia Paulucci Cianga Silvas

BIOTECNOLOGIA APLICADA AO TRATAMENTO DE DRENAGEM ÁCIDA DE MINA 
Flávia Paulucci Cianga Silvas

\section{BIOTECNOLOGIA APLICADA AO TRATAMENTO DE DRENAGEM ÁCIDA DE MINA}

Dissertação apresentada à Escola

Politécnica da Universidade de São Paulo para obtenção do título de Mestre em Engenharia.

\section{São Paulo}


Flávia Paulucci Cianga Silvas

\section{BIOTECNOLOGIA APLICADA AO TRATAMENTO DE DRENAGEM ÁCIDA DE MINA}

Dissertação apresentada à Escola Politécnica da Universidade de São Paulo para obtenção do título de Mestre em Engenharia.

Área de concentração: Engenharia Metalúrgica e de Materiais.

Orientador: Prof. Dr. Jorge Alberto Soares Tenório.

\section{São Paulo}




\section{DEDICATÓRIA}

Dedico este trabalho aos meus heróis:

Edson e Sueli. 


\section{AGRADECIMENTOS}

Ao Prof. Dr. Jorge Alberto Soares Tenório por me iniciar no mundo apaixonante da pesquisa, me orientar, me incentivar e me ensinar.

À Profá. Dra. Denise Crocce Romano Espinosa pelas inúmeras dicas, incentivo e apoio até mesmo nas conversas mais descontraídas.

Ao meu pai, Edson Luiz Cianga Silvas, e a minha mãe, Sueli Paulucci Cianga Silvas, por me possibilitarem essa experiência, pela paciência, confiança, compreensão, amizade, amor, carinho e dedicação desde sempre.

À Fefê - irmã, amiga e estagiária - pelo carinho e ajuda desprendida. Ao meu irmão, Bruno, pelo carinho e troca de informações.

Aos amigos do LAREX: Adriana Santanilla, Duca Ruggi, Du Junca, Fe Kameoka, Gyrlei Ferreira, Huguinho Hashimoto, Kelie Provazi, Victor Dotta, Bel Ramiro, Joner Alves. Em especial a Vivi Tavares pelas caronas, conversas, conselhos e risadas; a Danni Buzzi, uma convivente muito querida e especial; a Bia Amaral, Lu Yamane e Denis Massucatto pela ajuda e carinho, conversas e boas gargalhadas; e ao Victor Bridi pela companhia e auxilio nos cansativos finais de semana rodando ensaios.

Ao Prof. Dr. Arthur Pinto Chaves pela sua incansável disposição em ajudar e ao Prof. Dr. Mauricio Leonardo Torem pelas dicas, auxilio e orientação.

A todos os amigos e familiares. Infelizmente não foi possível citar a todos. Mas agradeço em especial aos tios Luiz e Eliane, pela paciência e carinho nos intermináveis dias de estudo.

Ao Prof. Ivo André Homrich Schneider e a Prof ${ }^{\mathrm{a}}$. Andrea Moura Bernardes por me receber com muito carinho e atenção em seus laboratórios.

À Profâa. Dra. Gelsa Maria Edith Navarro pela companhia, pelas dicas indispensáveis e pela enorme afeição.

Ao pessoal do Leamet, Lacor, e Laprom (UFRGS) por me receber de braços abertos e com muito carinho, contribuindo para uma experiência surpreendente. Em especial, a Prof ${ }^{\underline{a}}$. Rejane Maria Candiota Tubino e aos guris Rodrigo e Jean.

À Carbonífera Criciúma $S / A$ e ao SIECESC pela disponibilização de informações e amostras. E à Fapesp e Capes pelo apoio financeiro.

Obrigada a todos! 
"Tu deviens responsable pour toujours de ce que tu as apprivoisé."

"Tu te tornas eternamente responsável por aquilo que cativas."

Antoine-Jean-Baptiste-Marie-Roger Foscolombe de Saint-Exupéry 


\section{SUMÁRIO}

LISTA DE FIGURAS

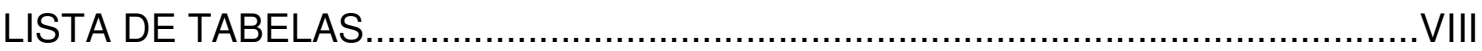

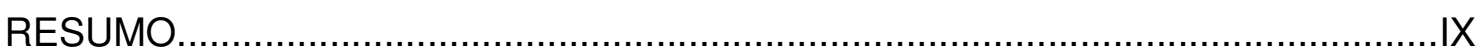

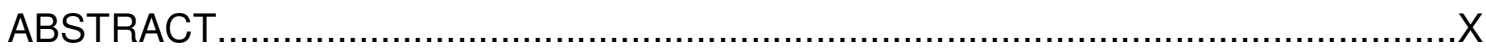

1 APRESENTAÇÃO

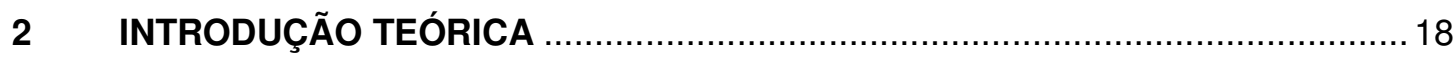

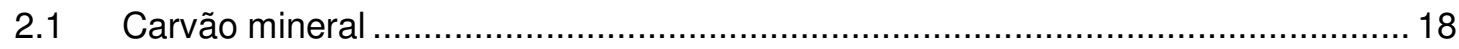

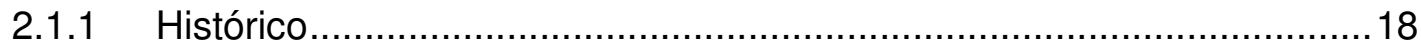

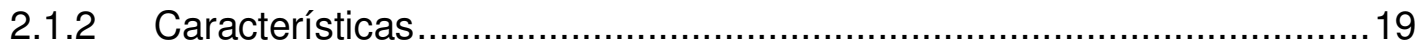

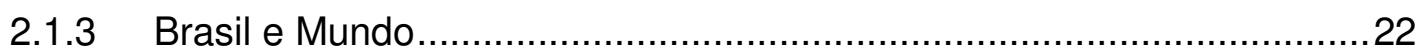

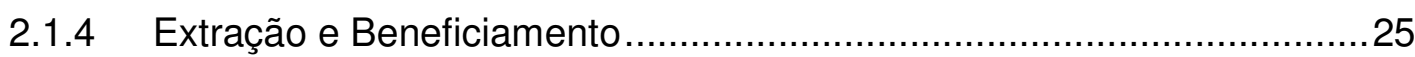

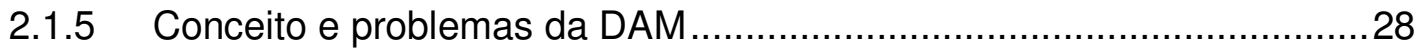

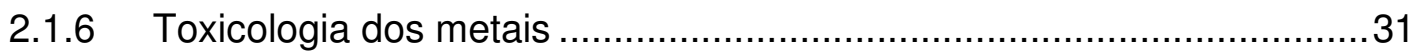

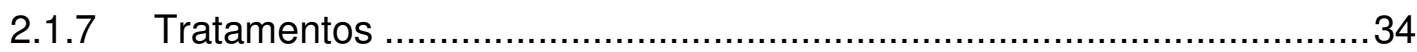

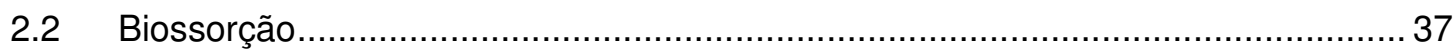

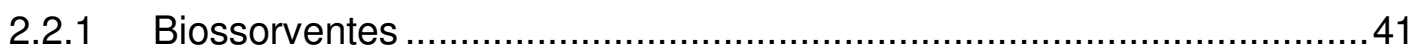

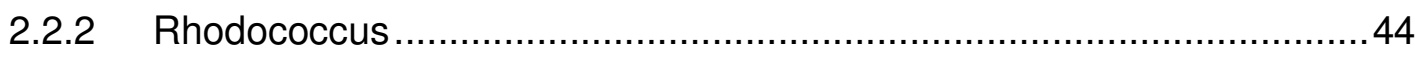

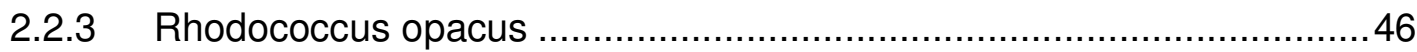

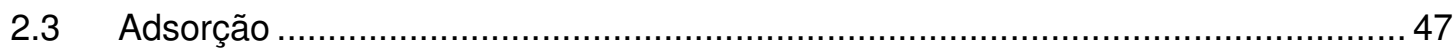

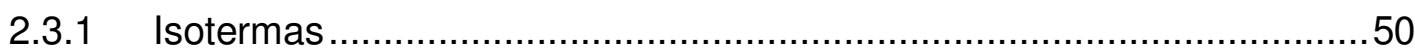

$3 \quad$ OBJETIVOS

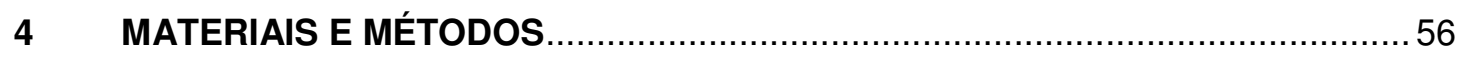

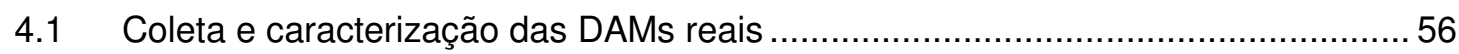

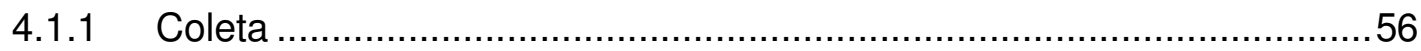

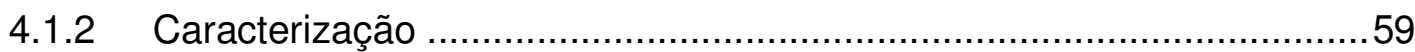

$4.1 \quad$ Preparação da DAM sintética ..................................................................... 59

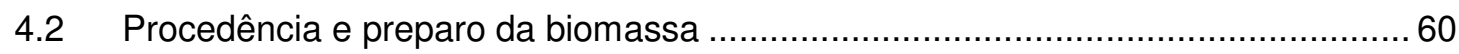

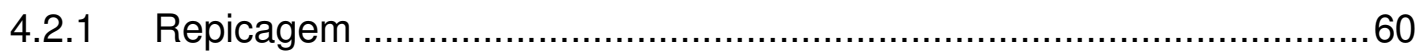

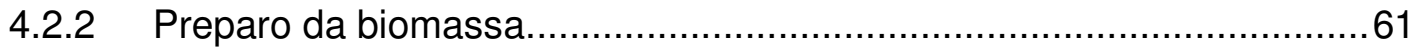

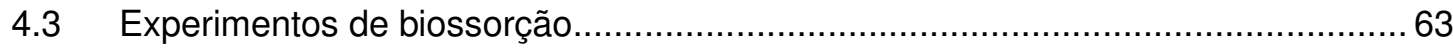

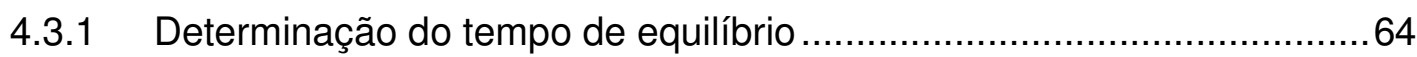

4.3.2 Análise quantitativa da concentração dos metais .....................................65

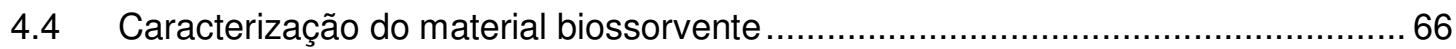

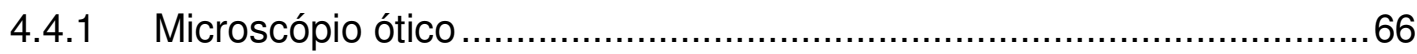

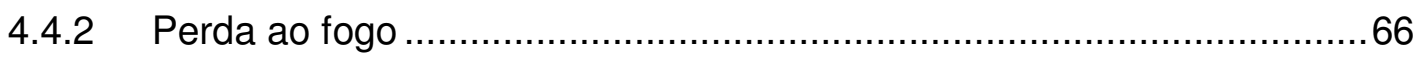

4.4.3 Microscopia Eletrônica de Varredura.................................................67 


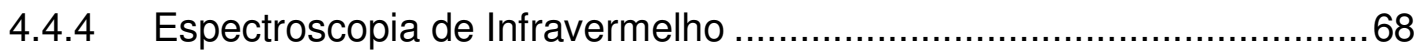

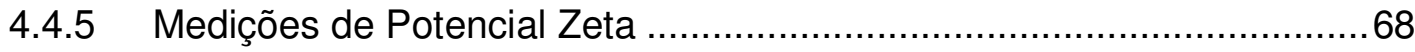

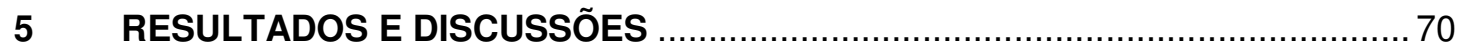

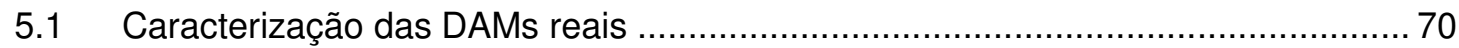

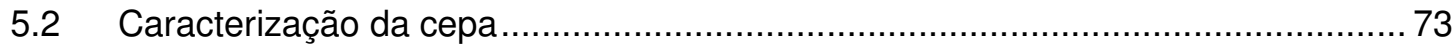

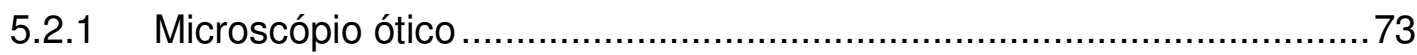

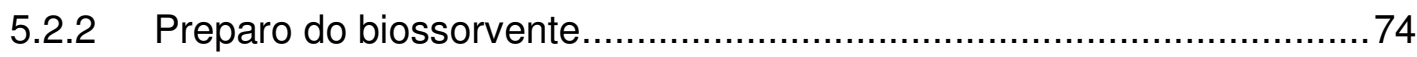

5.3 Caracterização da biomassa antes da biossorção................................................ 75

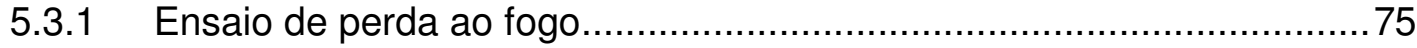

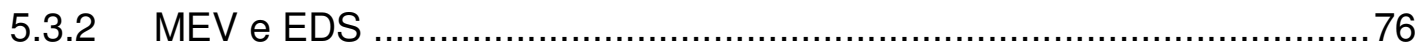

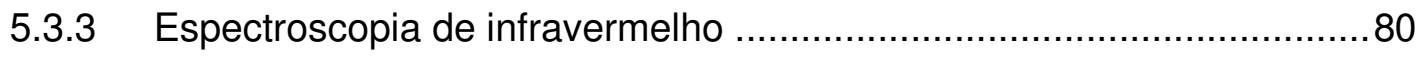

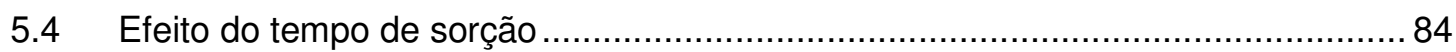

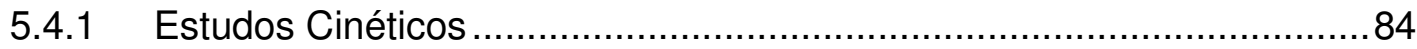

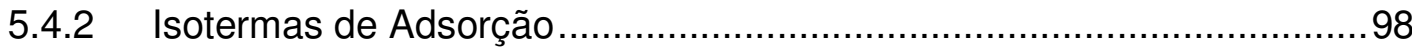

5.5 Caracterização da biomassa após ensaios biossortivos ....................................... 102

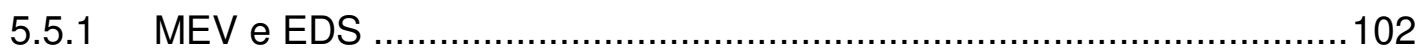

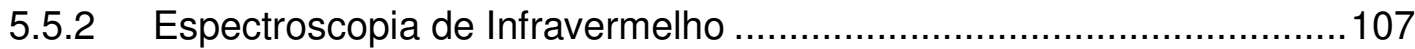

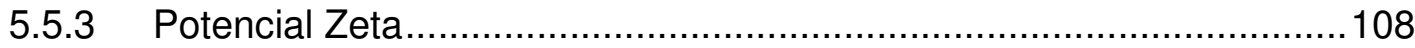

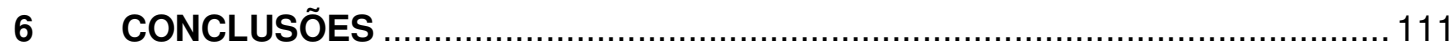

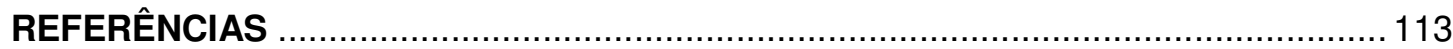




\section{LISTA DE FIGURAS}

Figura 1 - Principais camadas no Rio Grande do Sul e Santa Catarina ..................20

Figura 2 - Processos bioquímicos (A) e geoquímicos (B) envolvidos na origem do carvão 21

Figura 3 - Distribuição das reservas mundiais de carvão mineral em 2003 ..............23

Figura 4 - Localização das principais jazidas de carvão - RS, SC e PR ...................23

Figura 5 - Reservas de combustíveis fósseis no Brasil em \% ..................................24

Figura 6 - Produção de Carvão Mineral em Toneladas ...........................................24

Figura 7 - Fluxograma esquemático do beneficiamento do carvão. ........................26

Figura 8 - Diagrama esquemático dos produtos de beneficiamento do carvão ........27

Figura 9 - Cadeia de impactos ambientais na mineração de carvão ........................27

Figura 10 - Principais processos associados à geração de drenagens ácidas ........29

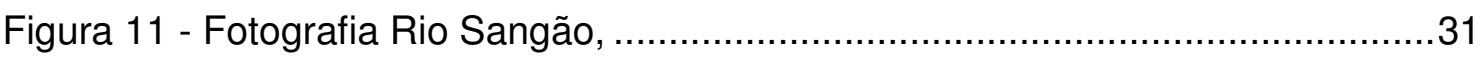

Figura 12 - Fotografia Pilhas de Rejeitos, Criciúma - SC ................................... 31

Figura 13 - Adsorção de moléculas na superfície do adsorvente..............................38

Figura 14 - Classificação do mecanismo de biossorção: dependência do

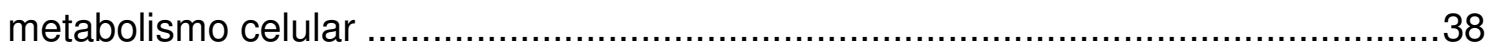

Figura 15 - Classificação do mecanismo de biossorção: sítio onde o metal é removido. 39

Figura 16 - Esquematização dos processos de interação entre metais e célula microbiana.

Figura 17 - Contorno esquemático da estrutura celular de bactérias gram-positivas

Figura 18 - Contorno esquemático da estrutura celular de bactérias gram-negativas

Figura 19 - Esquema do procedimento experimental para obtenção de dados para a

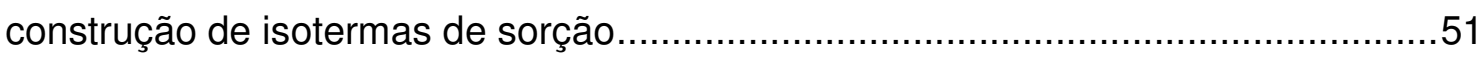

Figura 20 - Sistema para classificação de isotermas ........................................52

Figura 21 - Exemplos comparativos de isotermas de sorção …………………......53

Figura 22 - Bacia de adução EDR3, Forquilhinha - SC. ……...........................56

Figura 23 - Vista superior da carbonífera, em destaque a bacia de adução de onde

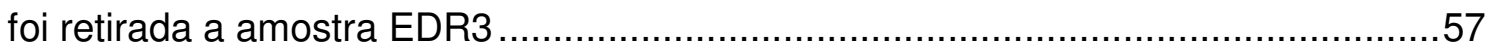

Figura 24 - Boca de mina abandonada, Criciúma - SC ........................................58 
Figura 25 - Fluxograma do sistema de drenagem da carbonífera onde foi coletada a amostra EDR3

Figura 26 - Fluxograma das etapas do processo de repicagem...........................60

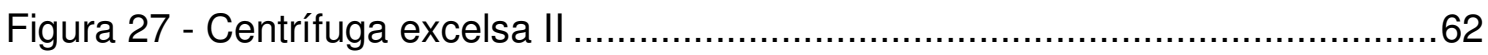

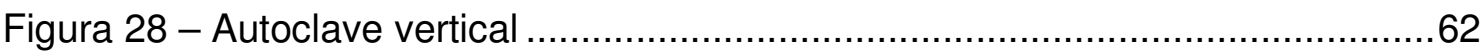

Figura 29 - Fluxograma das etapas do processo de preparação da biomassa .........63

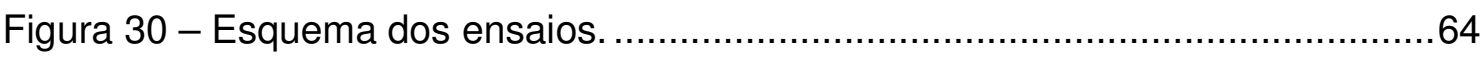

Figura 31 - Mufla Grion utilizada no ensaio de perda ao fogo. .............................67

Figura 32 - Biomassa, R. opacus, após ensaio de perda ao fogo. .........................67

Figura 33 - Caracterização das amostras EDR3 e SS16 em porcentagem ...............71

Figura 34 - Rhodococcus opacus visto em microscópio ótico. ................................73

Figura 35 - Precipitado obtido na centrifugação após lavagem.............................74

Figura 36 - Rhodococcus opacus após centrifugação: A) BUENO, 2007; B)

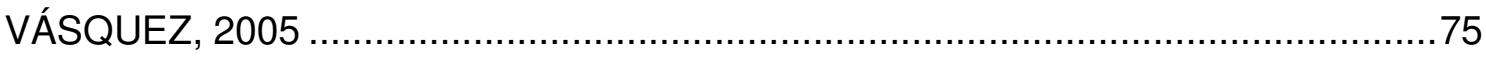

Figura 37 - Imagem de elétrons secundários da Rhodococcus opacus. ..................76

Figura 38 - Imagem de elétrons secundários do tamanho da Rhodococcus opacus.

Figura 39 - Imagens da Rhodococcus opacus obtidas por MEV: A) BUENO, 2007;

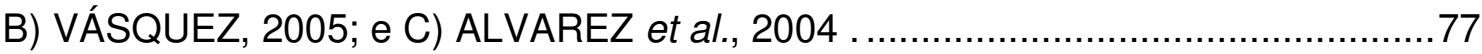

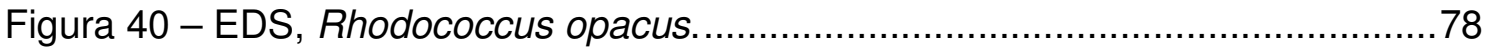

Figura 41 - EDS, Rhodococcus opacus (adaptado de BUENO, 2007) ....................79

Figura 42 - EDS, Rhodococcus opacus (adaptado de VÁSQUEZ, 2005) ................79

Figura 43 - Imagem de elétrons retroespalhados da Rhodococcus opacus após

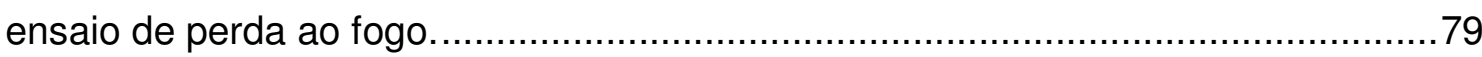

Figura 44 - Imagem de elétrons retroespalhados da Rhodococcus opacus após

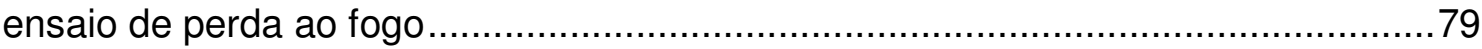

Figura 45 - EDS, Rhodococcus opacus após ensaio de perda ao fogo. ..................8 Figura 46 - Espectro da Rhodococcus opacus antes da biossorção obtido em infra-

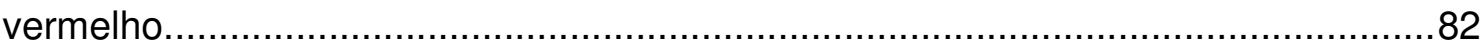

Figura 47 - FT-IR espectro da biomassa Rhodococcus opacus .............................83

Figura 48 - FT-IR espectro da biomassa Streptomyces rimosus sem .....................84

Figura 49 - Perfil do tempo na biossorção dos íons da solução sintética DAM WEI

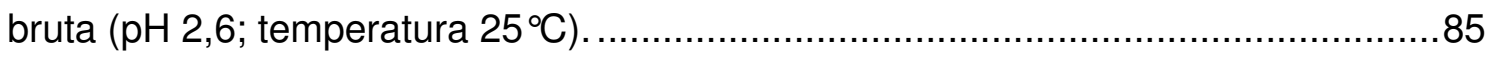


Figura 50 - Perfil do tempo na biossorção dos íons da solução sintética DAM WEI bruta $\left(\mathrm{pH} 2,6\right.$; concentração celular $1 \mathrm{~g} \cdot \mathrm{L}^{-1}$; temperatura $\left.25^{\circ} \mathrm{C}\right)$............................... 87

Figura 51 - Modelo de difusão externa aplicado a biossorção. ................................88

Figura 52 - Linearização do modelo de difusão externa para o Al na presença dos co-ions.

Figura 53 - Linearização do modelo de difusão externa para o Ca na presença dos co-ions.

Figura 54 - Linearização do modelo de difusão externa para o Fe na presença dos co-ions. 89

Figura 55 - Linearização do modelo de difusão externa para o Mg na presença dos co-ions.

Figura 56 - Linearização do modelo de difusão externa para o $\mathrm{Mn}$ na presença dos co-ions.

Figura 57 - Linearização do modelo de difusão externa para o Zn na presença dos co-ions. 89

Figura 58 - Modelo de difusão interna aplicado a biossorção. 90

Figura 59 - Linearização do modelo de difusão interna para o Al na presença dos coions. 91

Figura 60 - Linearização do modelo de difusão interna para o Ca na presença dos co-ions.

Figura 61 - Linearização do modelo de difusão interna para o Fe na presença dos co-ions.

Figura 62 - Linearização do modelo de difusão interna para o Mg na presença dos co-ions. 91

Figura 63 - Linearização do modelo de difusão interna para o $\mathrm{Mn}$ na presença dos co-ions.

Figura 64 - Linearização do modelo de difusão interna para o Zn na presença dos co-ions.

Figura 65 - Modelo de pseudo-primeira ordem aplicado a biossorção. 93

Figura 66 - Modelo de pseudo-primeira ordem para o Al na presença dos co-ions. 93 Figura 67 - Modelo de pseudo-primeira ordem para o Ca na presença dos co-ions. 93 Figura 68 - Modelo de pseudo-primeira ordem para o Fe na presença dos co-ions. 93 Figura 69 - Modelo de pseudo-primeira ordem para o Mg na presença dos co-ions.93 
Figura 70 - Modelo de pseudo-primeira ordem para o Mn na presença dos co-ions.

Figura 71 - Modelo de pseudo-primeira ordem para o Zn na presença dos co-ions. 94

Figura 72 - Modelo de pseudo-segunda ordem aplicado a biossorção: Metais 94

Figura 73 - Modelo de pseudo-segunda ordem para o Al na presença dos co-ions. 95 Figura 74 - Modelo de pseudo-segunda ordem para o Mg na presença dos co-ions.

Figura 75 - Modelo de pseudo-segunda ordem para o Ca na presença dos co-ions.

Figura 76 - Modelo de pseudo-segunda ordem para o $\mathrm{Mn}$ na presença dos co-ions 95 Figura 77 - Modelo de pseudo-segunda ordem para o Fe na presença dos co-ions.95 Figura 78 - Modelo de pseudo-segunda ordem para o Zn na presença dos co-ions.95 Figura 79 - Modelo de pseudo-segunda ordem aplicado a biossorção: Total. .96

Figura 80 - Equação de Langmuir para sistemas monoelementares para biossorção.

Figura 81 - Equação de Langmuir para sistemas monoelementares para biossorção do Al na presença de co-ions. 99

Figura 82 - Equação de Langmuir para sistemas monoelementares para biossorção do Ca na presença de co-ions

Figura 83 - Equação de Langmuir para sistemas monoelementares para biossorção do Fe na presença de co-ions. 99

Figura 84 - Equação de Langmuir para sistemas monoelementares para biossorção do Mg na presença de co-ions. 99

Figura 85 - Equação de Langmuir para sistemas monoelementares para biossorção do $\mathrm{Mn}$ na presença de co-ions. 100

Figura 86 - Equação de Langmuir para sistemas monoelementares para biossorção do $\mathrm{Zn}$ na presença de co-ions. 100 Figura 87 - Equação de Freundlich para sistemas monoelementares para biossorção 100

Figura 88 - Equação de Freundlich para sistemas monoelementares para biossorção do Al na presença de co-ions. 100

Figura 89 - Equação de Freundlich para sistemas monoelementares para biossorção do Ca na presença de co-ions. 100 
Figura 90 - Equação de Freundlich para sistemas monoelementares para biossorção do Fe na presença de co-ions............................................................101

Figura 91 - Equação de Freundlich para sistemas monoelementares para biossorção do Mg na presença de co-ions.....................................................101

Figura 92 - Equação de Freundlich para sistemas monoelementares para biossorção do Mn na presença de co-ions........................................................101

Figura 93 - Equação de Freundlich para sistemas monoelementares para

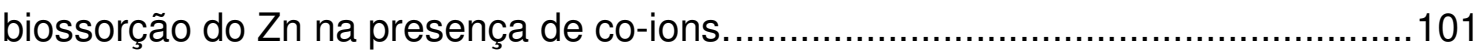

Figura 94 - Imagem de elétrons secundários da biomassa após 1 min...................103

Figura 95 - Imagem de elétrons secundários da biomassa após 3min. ...................103

Figura 96 - Imagem de elétrons secundários da biomassa após 5min...................103

Figura 97 - Imagem de elétrons secundários da biomassa após 10min.................103

Figura 98 - Imagem de elétrons secundários da biomassa após 10min: lise celular.

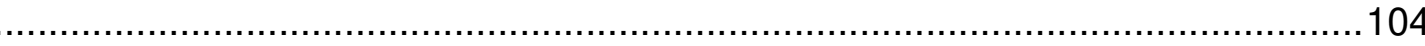

Figura 99 - Imagem de elétrons secundários da biomassa após 10min: ................105

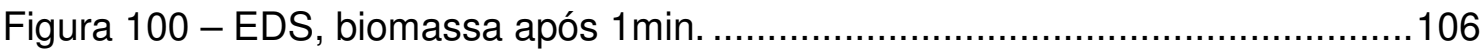

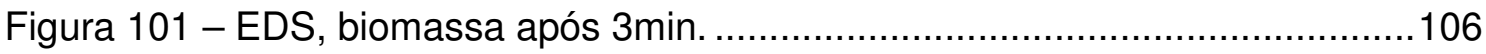

Figura 102 - EDS, biomassa após 5min. ......................................................106

Figura 103 - EDS, biomassa após 10min: região clara …………………….....106

Figura 104 - EDS, biomassa após 10min: região escura. …………...................106

Figura 105 - Espectros da biomassa de Rhodococcus opacus antes ....................107

Figura 106 - Potencial Zeta das células Rhodococcus opacus .............................109

Figura 107 - Potencial zeta da biomassa após biossorção. ...................................110 


\section{LISTA DE TABELAS}

Tabela 1 - Variação dos constituintes principais em \% .......................................21

Tabela 2 - Principais tipos e métodos de lavras ……….....................................25

Tabela 3 - Características típicas da drenagem ácida de minas. ............................30

Tabela 4 - Tecnologias convencionais para remoção de metais de efluentes ...........36

Tabela 5 - Grupos químicos de ligação envolvidos na biossorção............................42

Tabela 6 - Características de diversas espécies do gênero Rhodococcus ...............45

Tabela 7 - Composição da parede celular da Rhodococcus opacus........................47

Tabela 8 - Diferenças entre adsorção física e adsorção química..............................48

Tabela 9 - Características da drenagem ácida de minas ..........................................60

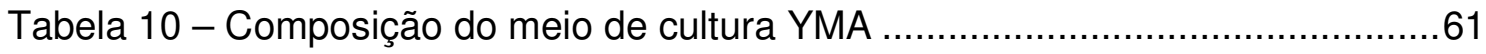

Tabela 11 - Condições empregadas para determinação do tempo de equilíbrio .....65

Tabela 12 - Características das DAMs coletadas ................................................70

Tabela 13 - Dados coletados no ensaio de perda ao fogo ......................................75

Tabela 14- Relação entre as bandas de absorção de infravermelho e grupos

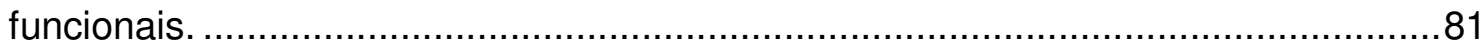

Tabela 15 - Metais segundo algumas características físicas ……………….......... 86

Tabela 16 - Parâmetros cinéticos para a biossorção dos metais presentes na DAM por

Tabela 17 - Parâmetros cinéticos encontrados na literatura: modelo cinético de

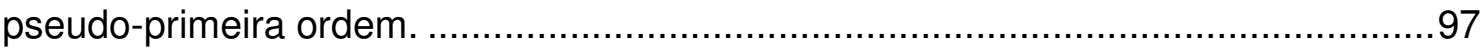

Tabela 18 - Parâmetros cinéticos encontrados na literatura: modelo cinético de

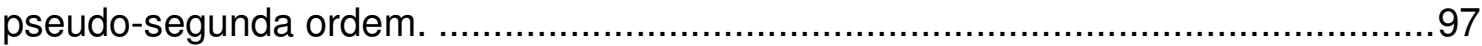

Tabela 19 - Constantes de adsorção para os modelos de Langmuir e Freundlich encontradas na literatura. 102 


\section{RESUMO}

Proveniente das atividades de mineração, a drenagem ácida de minas (DAM) é uma solução aquosa caracterizada por valores de pH menores que 3 e diversidade de metais dissolvidos com concentrações que variam de 100 a 300mg.L-1, representa riscos ambientais, em especial, impactos hídricos, em conseqüência da solubilização e mobilização de metais pesados. A pesquisa por novos processos de tratamento de efluentes contaminados com metais tem focado sua atenção na capacidade que certos materiais biológicos têm de fixar íons metálicos. A biossorção é um processo vantajoso quando comparado aos tratamentos convencionais porque não requer custos de investimento e operação, é um processo rápido e pode ser seletivo, além disso, o metal pode ser recuperado e o biossorvente reutilizado. Rhodococcus opacus é uma bactéria, gram-positiva, não patogênica, de fácil aquisição que apresenta em sua parede celular compostos que the conferem hidrofobicidade, características que tornam esta espécie microbiana um potencial agente de sorção. $\mathrm{O}$ objetivo deste trabalho é avaliar a capacidade do Rhodococcus opacus como biossorvente destinado ao tratamento da drenagem ácida de minas proveniente da mineração de carvão. As características da superfície do microrganismo e os possíveis mecanismos de interação envolvidos na sorção dos metais pelo Rhodococcus opacus foram avaliados através da medida de potencial zeta, análise de espectroscopia de infravermelho e análise de imagens obtidas no microscópio eletrônico de varredura (MEV). A porcentagem de metais presentes na composição das células de Rhodococcus opacus foi obtida através do ensaio de perda ao fogo e é de aproximadamente 1,8\%. O equilíbrio do processo biossortivo em sistema multimetálico foi atingido em cerca de 1 minuto, captando $48,2 \mathrm{mg} \cdot \mathrm{g}^{-1} \mathrm{o}$ que correspondo a aproximadamente $11,7 \%$ de remoção. O PIE da Rhodococcus opacus ocorreu em pH próximo a 2,6. 


\begin{abstract}
Originating from mining and mineral industry activities, the acid mine drainage (AMD) is an aqueous solution with $\mathrm{pH}$ lower than 3 and diversity of dissolved metals, with concentrations about 100 to $300 \mathrm{mg}^{-1} \mathrm{~L}^{-1}$, leads to serious environmental problems, specially on acquatic ecosystems, due to the solubilization of heavy metals. The search for new technologies on the treatment of effluents contaminated with metals is focused on some biological materials capacity of binding metallic ions. Treatment by biosorption is worthwhile when compared with conventional processes because it does not require high investiments, it is faster, metals can be recovered and biosorbent can be regenerated. Rhodococcus opacus is a gram-positive, nonpathogenic bacteria, that is easily obtained. Its hydrophobicity is due to compounds present in its surface. Such characteristics turn these microorganisms into a potential sorption agent. This paper aims to evaluate the Rhodococcus opacus capacity as a biosorbent in AMD treatment by batch experiments. The characteristics of the microorganism surface and the involved interaction mechanisms in the heavy metals sorption by Rhodococcus opacus, was evaluated based in the potential zeta measurements, infrared spectroscopy and electron microscopy scanning analysis. The metals percentage present in the composition of Rhodococcus opacus cells was obtained by loss on ignation technique, and was approximately $1.8 \%$. The equilibrium of biosorptive process in the multi-metallic system was achieved at about 1 minute, uptake $48.2 \mathrm{mg}^{-1}$ corresponding to approximately $11.7 \%$ of removal. The Rhodococcus opacus IEP occurred at $\mathrm{pH}$ around 2.6.
\end{abstract}




\section{APRESENTAÇÃO}

Proveniente de atividades de mineração, a drenagem ácida de minas (DAM) é uma solução aquosa com pH geralmente abaixo de 3 e diversidade de metais dissolvidos, que quando em contato com os recursos hídricos causam inúmeros efeitos toxicológicos aos ecossistemas aquáticos. Sua acidez age na dissolução de outros metais presentes na matéria mineral e agrava ainda mais o problema.

O tratamento convencional da DAM é realizado pela neutralização e precipitação dos metais na forma de hidróxidos gerando lodo. As lamas não têm nenhum valor comercial, o que torna a destinação desse resíduo economicamente desfavorável.

Processos de tratamento estão sendo estudados, porém a aplicação de algumas dessas metodologias resulta em custos, incompleta remoção dos metais, consumo de energia e reagentes, além da geração de outros resíduos.

Os problemas associados com os tratamentos estudados até o momento e o estabelecimento de normas rígidas, assim como a conscientização ambiental, estão apontando para a necessidade de pesquisas visando o desenvolvimento de novas tecnologias que promovam eficiência de remoção adjunta ao custo, objetivando atingir os limites de toxicidade permitidos na legislação.

Dentre essas novas tecnologias, os processos biossortivos apresentam potencial, sendo caracterizados pelo uso de materiais adsorventes baratos, não tóxicos e biodegradáveis.

A biossorção tem sido estudada durante as três últimas décadas para diferentes combinações de metal/biomassa e diversas condições experimentais. Esta técnica está baseada na capacidade que certos materiais de origem natural têm de captar metais. Sua utilização apresenta como vantagens custos de investimento e operação, rapidez do processo, seletividade, possibilidade de recuperação do metal e de reutilização do biossorvente.

Diversos materiais biológicos têm sido empregados nos estudos de captação de metais dentre eles: fungos filamentosos, bactérias, leveduras e algas pela habilidade de captação que possuem conferidos pelos grupos funcionais presentes em suas superfícies. 
Este trabalho propõe o estudo do Rhodococcus opacus como biossorvente aplicado ao tratamento da DAM. Esta bactéria apresenta em sua parede celular compostos como polissacarídeos, ácidos carboxílicos, ácidos micólicos e lipídeos que the conferem alta hidrofobicidade, além disso, não apresenta patogenicidade e é de fácil aquisição. Estas características tornam esta espécie microbiana um potencial agente de sorção. 


\section{INTRODUÇÃO TEÓRICA}

\subsection{Carvão mineral}

\subsubsection{Histórico}

A mineração de carvão no Brasil iniciou-se, oficialmente, no ano de 1861, no município de Lauro Müller - SC (LOPES, SANTO \& GALATTO, 2009). Inicialmente o carvão era explorado por uma empresa inglesa que após algum tempo de extração, considerou o carvão catarinense de baixa qualidade o que acabou por inibir o interesse inglês. Por volta de 1855, foi aberta uma mina no Rio Grande do Sul para produção de carvão extraído em Arroio dos Ratos e em meados de 1863, a mineração de carvão nas localidades de Candiota e Hulha Negra ocorriam em minas de encosta e às margens de cursos de água (ORLANDI FILHO, KREBS \& GIFFONI, 2002; SIECESC, 2010).

Concomitante com a Primeira Guerra Mundial ocorreu um "boom" na exploração de carvão nacional. Nessa época, os ramais ferroviários foram ampliados e novas empresas de mineração foram inauguradas: em 1917 entra em operação a Companhia Brasileira Carbonífera Araranguá (CBCA); em 1918, a Companhia Carbonífera Urussanga (CCU); em 1921, surgem a Companhia Carbonífera Próspera e a Companhia Carbonífera Ítalo-Brasileira; e em 1922, a Companhia Nacional Mineração Barro Branco (ORLANDI FILHO, KREBS \& GIFFONI, 2002; SIECESC, 2010).

O segundo surto de explotação ocorreu no Governo Getúlio Vargas, com a construção da Companhia Siderúrgica Nacional - CSN e pela política Nacional para o consumo de carvão (CETEM, 2001), o decreto determinava o uso de $20 \%$ de carvão nacional em sua operação, na composição do coque. Na década de 70, com a crise do petróleo, as atenções voltaram-se novamente para o uso do carvão nacional e o governo, através do Programa de Mobilização Energética - PME, incentivou o consumo do carvão nacional (KOPPE \& COSTA, 2008). Porém, no início da década de 90, ocorreu a privatização do Complexo Siderúrgico Nacional e 
com ela o decréscimo da produção de carvão metalúrgico (mais de $15 \%$ do total) (LOPES, SANTO \& GALATTO, 2009).

Cabe ressaltar que o início da exploração de carvão mineral em Santa Catarina se deu com a escavação manual de inúmeras bocas de minas nas encostas, onde afloram as camadas de carvão. Estas escavações eram realizadas com o uso de ferramentas manuais, portanto nas porções mais alteradas e brandas da camada se tornava possível a exploração, mas com o avanço das galerias o minério se tornava muito duro para ser explorado manualmente. Assim, eram abandonadas as frentes de lavras, dando-se início a abertura de uma nova boca de mina (AMARAL, KREBS \& PAZZETTO, 2009). Observa-se hoje no município de Criciúma - SC que muitas dessas bocas de minas abandonadas continuam com DAM desde sua abertura.

\subsubsection{Características}

O carvão origina-se da transformação, lenta e progressiva, de restos vegetais que permanecem soterrados, o que impede a sua completa decomposição (TOSATTO, 2005). As diferenças na composição dos carvões, e também da sua qualidade (GOMES, 2002), são oriundas da diversidade de matéria vegetal no local de formação, da profundidade de enterramento, das temperaturas e pressões nessas profundidades e do tempo de formação do carvão no depósito (LOPES, SANTO \& GALATTO, 2009; WORLD COAL INSTITUTE, 2010). A maturação do carvão está intimamente ligada a essas características, que por sua vez possui relação com a idade geológica das rochas. O carvão brasileiro tem 295 milhões de anos e pertence ao período Permiano da era Paleozóica (GOMES, 2002).

Segundo Orlandi Filho, Krebs \& Giffoni (2002), todas as camadas explotadas no país encontram-se associadas às litologias da formação Rio Bonito, do Grupo Guatá. Estas camadas recebem diferentes denominações regionais em cada jazida (Figura 1):

- No Rio Grande do Sul: Camada Candiota; S2 e I na Mina do Leão; CL4 na jazida Chico Lomã; 
- Em Santa Catarina são conhecidas a Camada Barro Branco, Camada Bonito e Camada Irapuá; Sendo que para uso em siderurgia somente pode ser utilizado o carvão da camada Barro Branco, isso porque as demais camadas apresentam alto teor de cinzas e baixo poder calorífico o que reduz o emprego deste carvão a fins energéticos ou à fabricas de cimentos.

- No Paraná ocorre a Figueira/Sapopema.

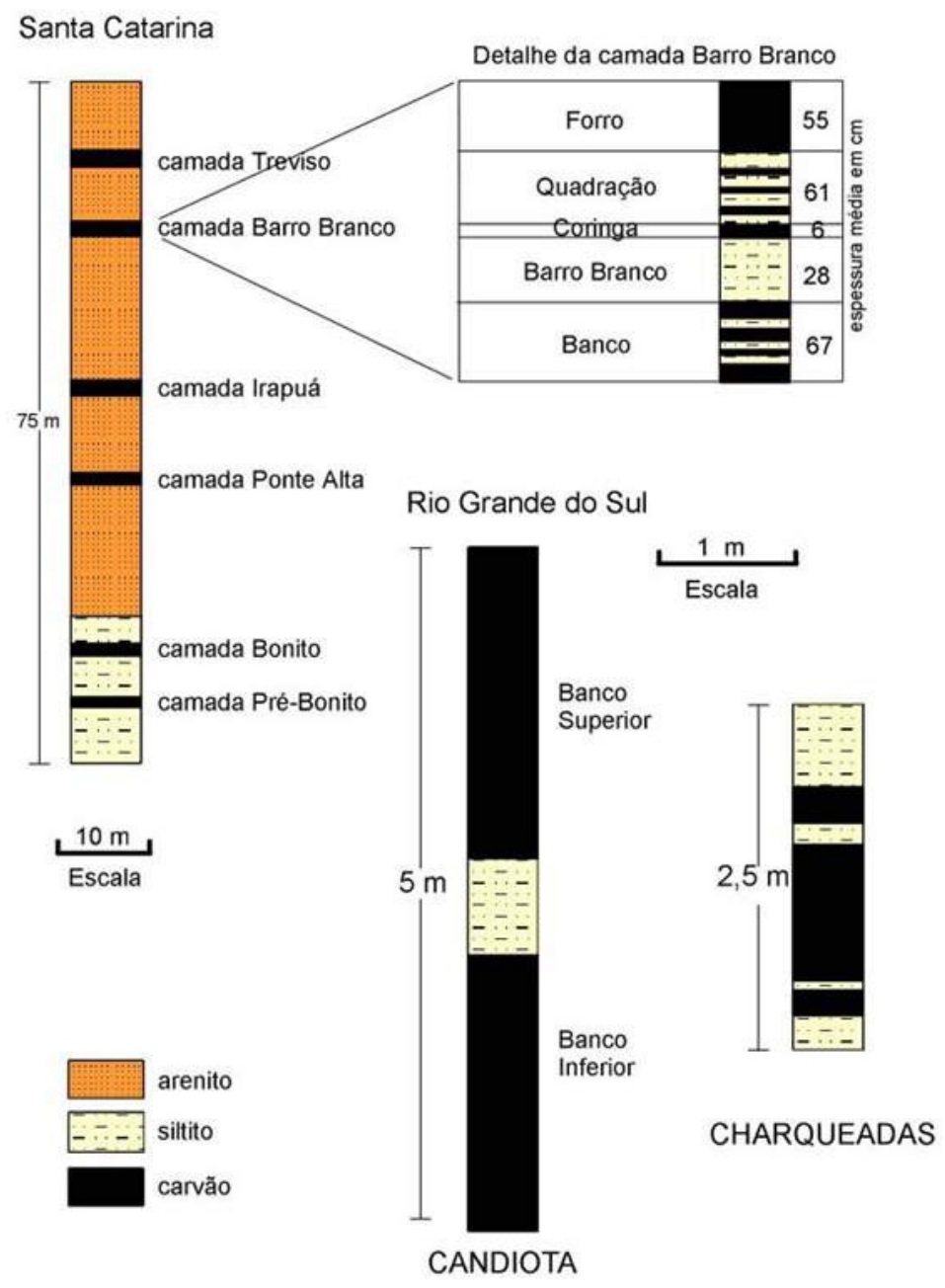

Figura 1 - Principais camadas no Rio Grande do Sul e Santa Catarina (ORLANDI FILHO, KREBS \& GIFFONI, 2002)

A camada Barro Branco, apesar de bastante uniforme, pode ser dividida em duas regiões segundo a produção possível de carvão metalúrgico e carvão vapor:

- Região do alto metalúrgico: caracteriza-se por produção de carvão metalurgico com $18,5 \%$ de cinzas bem superior a de carvão vapor. 
- Região do médio e baixo metalúrgico: fornece uma produção de carvão metalúrgico da mesma ordem da de carvão vapor (CHAVES,1982).

Conforme as condições geológicas, os jazidos de carvão são classificados em autóctones (formação carbonífera a partir da vegetação local) ou alóctones (depósitos resultantes do transporte de vegetais por correntes de água) (MACHADO, 2007).

A massa vegetal acumulada passa por transformações graduais que envolvem processos bioquímicos e geoquímicos (Figura 2, A e B respectivamente), neste ultimo processo, conforme ocorre enriquecimento em carbono há diminuição das matérias voláteis contidas, do hidrogênio e do oxigênio (CARRISSO \& POSSA, 1995; CHAVES, 1972). Na Tabela 1 encontram-se as variações dos constituintes do carvão e seus tipos.
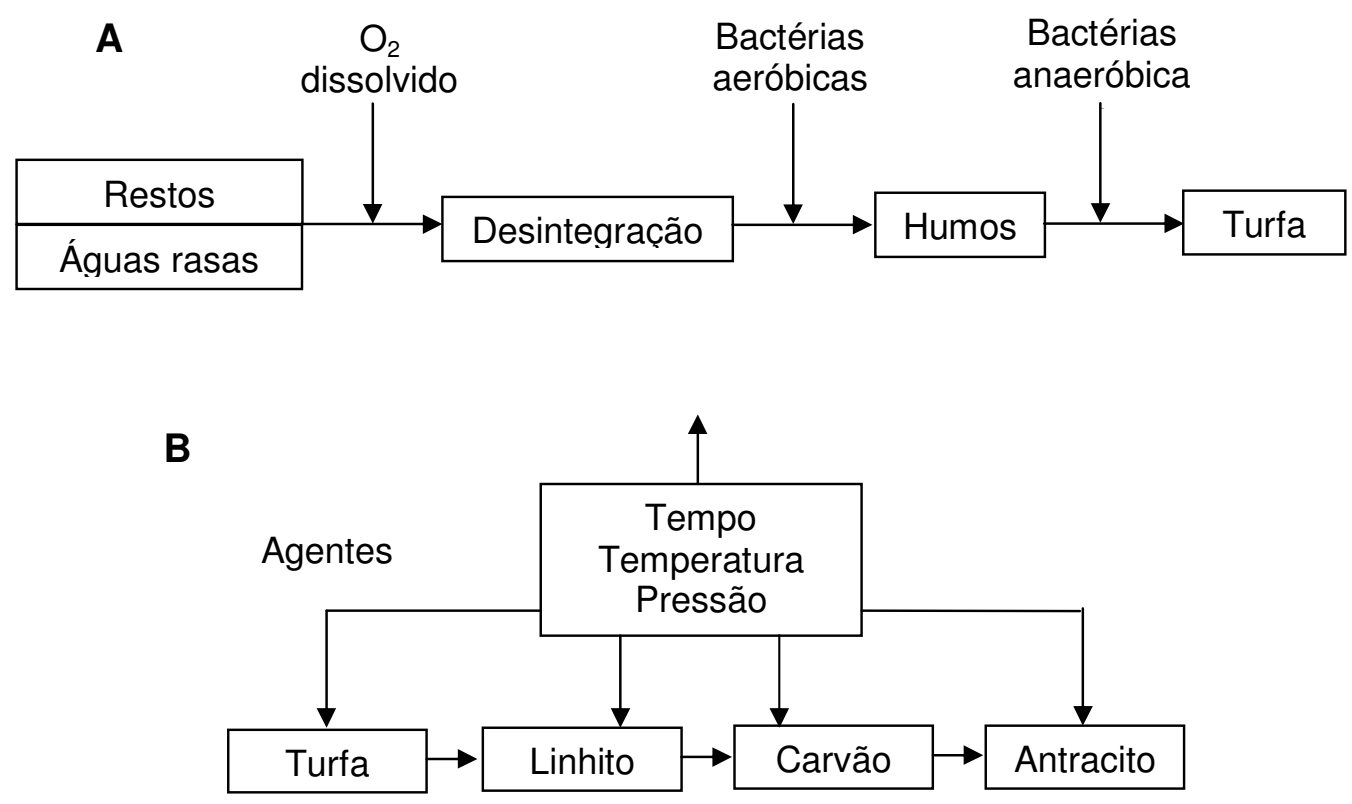

Figura 2 - Processos bioquímicos (A) e geoquímicos (B) envolvidos na origem do carvão (adaptado de CARRISSO \& POSSA, 1995).

Tabela 1 - Variação dos constituintes principais em \% (GOMES, 2002)

\begin{tabular}{c|ccc}
\hline Tipo & Carbono & Hidrogênio & Oxigênio \\
\hline Madeira & 50 & 6 & 43 \\
Turfa & $55-60$ & 6 & $34-39$ \\
Linhito & $67-78$ & 5 & $17-28$ \\
Hulha & $80-90$ & 5 & $4,5-15$ \\
Antracito & 96 & 2 & 2 \\
\hline
\end{tabular}


A classificação do carvão pode ser feita segundo os parâmetros geométricos (espessura, cobertura, extensão...) e a qualidade físico-química. Neste ultimo grupo de parâmetros é possível classificar os carvões segundo o rank (estudo do grau de evolução/grau de maturação atingido através da evolução geológica, medido através da analise de carbono fixo, matéria volátil, poder calorífico...) e o grade (relação entre matéria orgânica/inorgânica e as características da última) (GOMES, 2002)

As principais diferenças estruturais entre os tipos de carvão são:

- linhitos e carvões sub betuminosos: contem estruturas cíclicas que não são aromáticas nem hidroaromáticas;

- carvões betuminosos de "rank" inferior contêm grandes quantidades de estruturas hidroaromáticas;

- conforme cresce o "rank" desses carvões, aumentam as quantidades de estruturas aromáticas. (CHAVES, 1972).

De acordo com a classificação americana, os carvões brasileiros sul-riograndenses pertencem a classe dos sub-betuminosos " $\mathrm{C}$ " e "B" e os catarinenses a dos altos voláteis "A".

\subsubsection{Brasil e Mundo}

Estima-se que existam mais de 984 bilhões de toneladas de reservas de carvão mineral em todo mundo. Essas reservas estão distribuídas por todos os continentes e em mais de 70 países, contudo as maiores reservas estão localizadas nos Estados Unidos, Rússia, China e Índia (Figura 3).

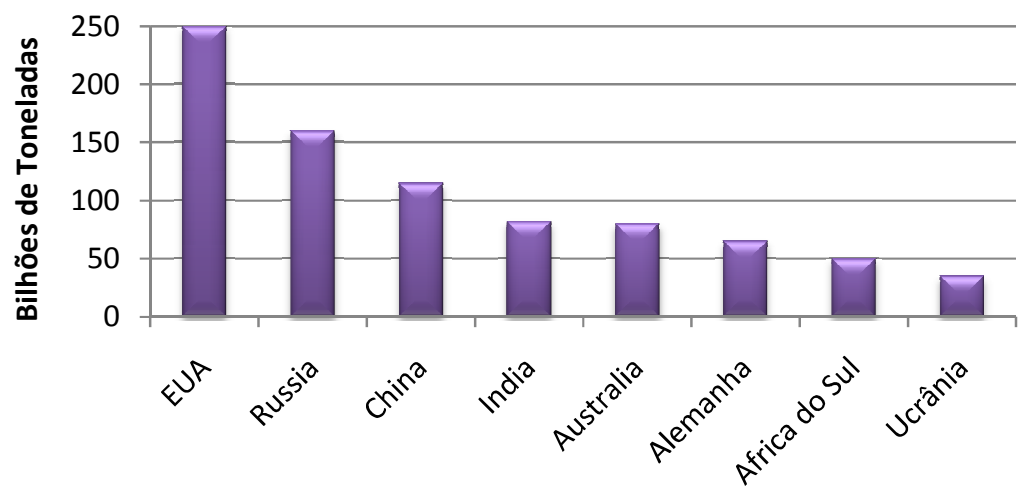


Figura 3 - Distribuição das reservas mundiais de carvão mineral em 2003 (adaptado de WORLD COAL INSTITUTE, 2010)

O Brasil dispõe de reservas que totalizam 7059 milhões de toneladas de carvão mineral (BP STATISTICAL REVIEW OF WORLD ENERGY, 2009), respondendo por apenas $0,1 \%$ das reservas mundiais e, $0,1 \%$ pela produção total global (LOPES, SANTO \& GALATTO, 2009). A produção de carvão mineral brasileira concentra-se na região sul do país. Segundo Neves \& Silva (2007), 74\% das minas ativas em 2006 encontram-se no estado de Santa Catarina, 22\% no Rio Grande do Sul e o restante no Paraná (Figura 4).

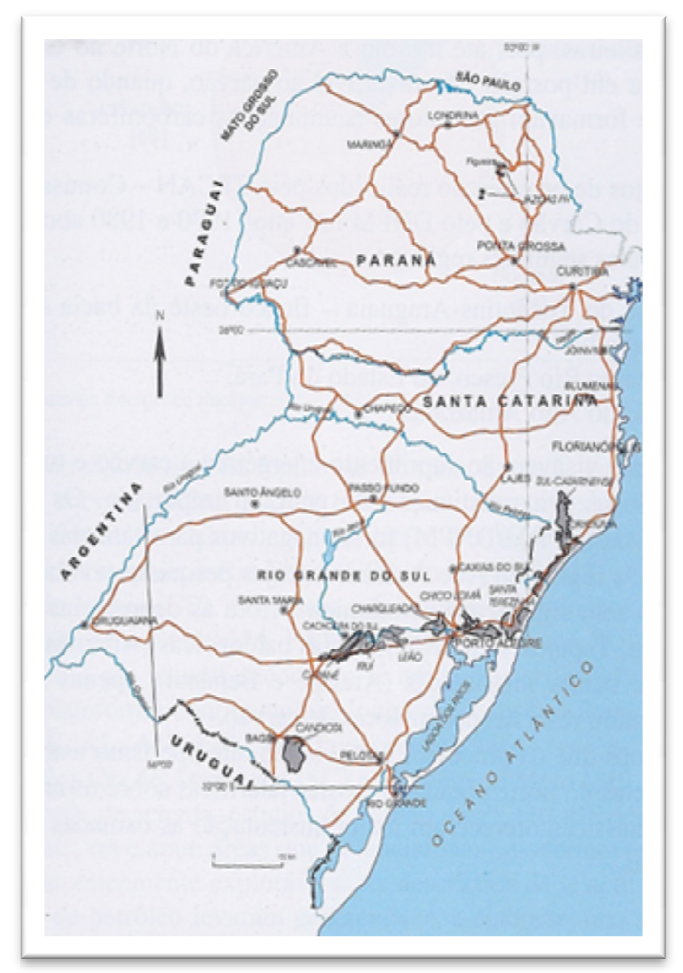

Figura 4 - Localização das principais jazidas de carvão - RS, SC e PR (GOMES, 2002)

Segundo de Luca (2003), em termos energéticos, o carvão mineral corresponde por 2/3 dos recursos não renováveis do Brasil. Já, Gomes (2002), afirma que o carvão representa $50 \%$ dos combustíveis fósseis nacionais (Figura 5). 


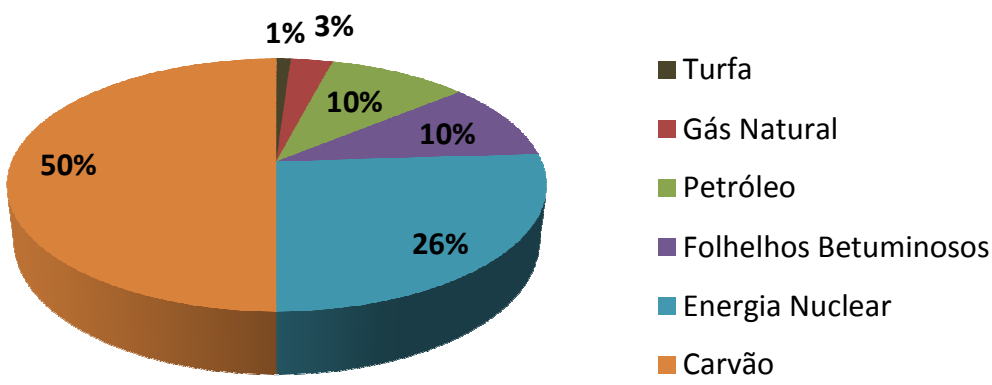

Figura 5 - Reservas de combustíveis fósseis no Brasil em \% (adaptado de GOMES, 2002)

Em 2003, como conseqüência do início de um período de prosperidade da economia mineral, ocorreu um aumento significativo na demanda de commodities provocando um aumento dos preços dos bens minerais. Impulsionada pela demanda global por commodities minerais, ações míneroempreendedoras foram firmadas resultando em significativo aumento no fluxo de investimentos mundiais em exploração mineral, alcançando a ordem de US\$14,4 milhões em 2008, 26,3\% acima de 2007 em particular de venture capital, com ênfase ao carvão, cobre, molibdênio, ouro e urânio (RODRIGUES, 2009).

No segundo semestre de 2008 foram produzidas mais de 4,1 milhões de toneladas de carvão bruto, sendo que destas foram beneficiadas 2,4 milhões toneladas de carvão energético (CE) e apenas 7,8 mil toneladas de carvão metalúrgico $(\mathrm{CM})$. A produção de $\mathrm{CM}$ apresentou crescimento de $25 \%$ do segundo semestre de 2006 para o mesmo período de 2007 e de $118 \%$ para 2008 (BORBA \& ARAÚJO, 2009), como pode ser observado na Figura 6.

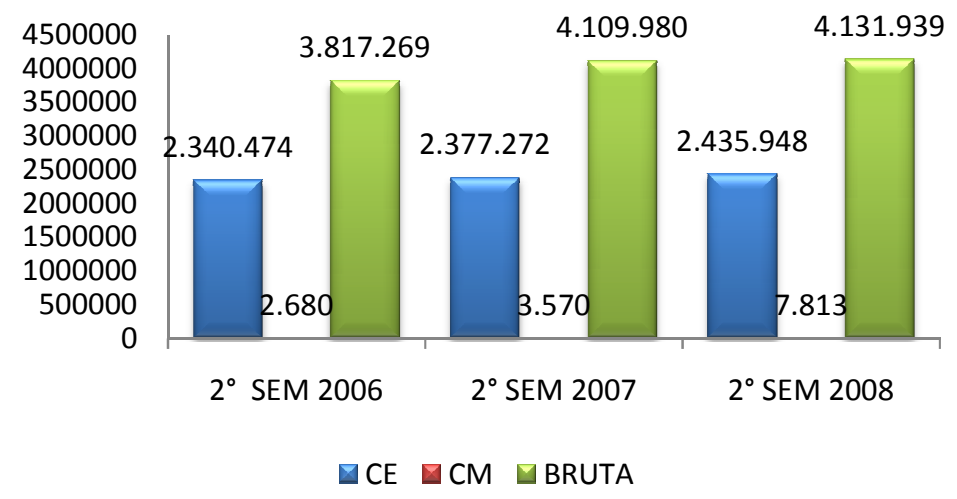

Figura 6 - Produção de Carvão Mineral em Toneladas (adaptado de BORBA \& ARAÚJO, 2009) 


\subsubsection{Extração e Beneficiamento}

A lavra do carvão pode ser feita a céu aberto ou subterrânea, sendo que estas se subdividem em outros métodos conforme Tabela 2.

Tabela 2 - Principais tipos e métodos de lavras

(adaptado de KOPPE \& COSTA, 2008)

\begin{tabular}{|c|c|c|}
\hline Lavra & Método & Características \\
\hline \multirow{3}{*}{ 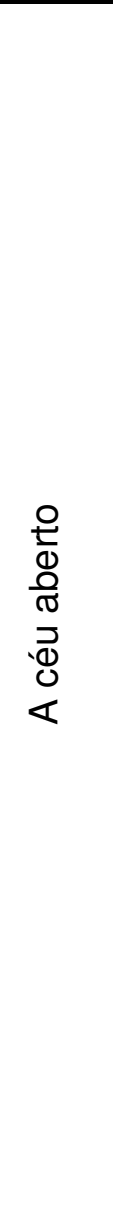 } & $\begin{array}{c}\text { Lavra em } \\
\text { Tiras }\end{array}$ & $\begin{array}{l}\text { - mais utilizada para extração a céu aberto; } \\
\text { - remoção inicial da cobertura superficial que recobre } \\
\text { as camadas de carvão; } \\
\text { - impactos ambientais relacionados a grande } \\
\text { quantidade de estéril retirada. }\end{array}$ \\
\hline & $\begin{array}{c}\text { Lavra de } \\
\text { descobertura } \\
\text { com dragline }\end{array}$ & $\begin{array}{l}\text { - abertura de um corte inicial, remoção do carvão neste } \\
\text { corte e disposição do material de cobertura do próximo } \\
\text { corte dentro deste inicial; } \\
\text { - empregado em depósitos de carvão com camadas } \\
\text { horizontalizadas ou moderadamente inclinadas, com } \\
\text { espessuras constantes do material de cobertura. }\end{array}$ \\
\hline & $\begin{array}{l}\text { Lavra em } \\
\text { bancadas/ } \\
\text { escavadeira }\end{array}$ & $\begin{array}{l}\text { - abertura de uma cava colocando a cobertura extraída } \\
\text { em uma área de bota-fora temporária; remoção do } \\
\text { carvão desta cava inicial e depósito da cobertura para } \\
\text { a área já lavrada; } \\
\text { - empregado em depósitos com camadas de carvão } \\
\text { espessas, horizontalizadas ou levemente inclinadas e } \\
\text { que apresentem baixa razão de cobertura. }\end{array}$ \\
\hline 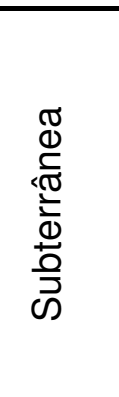 & $\begin{array}{l}\text { Método de } \\
\text { câmeras e } \\
\text { pilares }\end{array}$ & $\begin{array}{l}\text { - o carvão é extraído a partir de câmeras retangulares } \\
\text { deixando partes do carvão entre as câmeras como } \\
\text { pilares; } \\
\text { - empregado em depósitos com camadas horizontais } \\
\text { ou levemente inclinadas nos quais o teto é sustentado } \\
\text { primeiramente por pilares naturais; }\end{array}$ \\
\hline
\end{tabular}


Nas minas de Santa Catarina, Apenas 27\% do minério extraído (ROM) é carvão energético e outros produtos. A maior parte, 73\%, são rejeitos piritosos retirados ao longo processo de beneficiamento (MACHADO, PERUFFO \& LIMA, 1984 apud LOPES, SANTO \& GALATTO, 2009).

A mecanização das minas obriga à retirada de todo o material presente, carvão e intercalações. Assim é necessário uma pré-lavagem na boca-da-mina para eliminar o estéril (CHAVES,1982).

O beneficiamento é feito visando o aproveitamento mais econômico do carvão minerado (GOMES, 2002). O fluxograma apresentado na Figura 7 demonstra os processos padrões utilizados, porém dependendo das características físico-químicas do minério, podem ocorrer modificações tanto seqüência das etapas como na escolha dos processos.

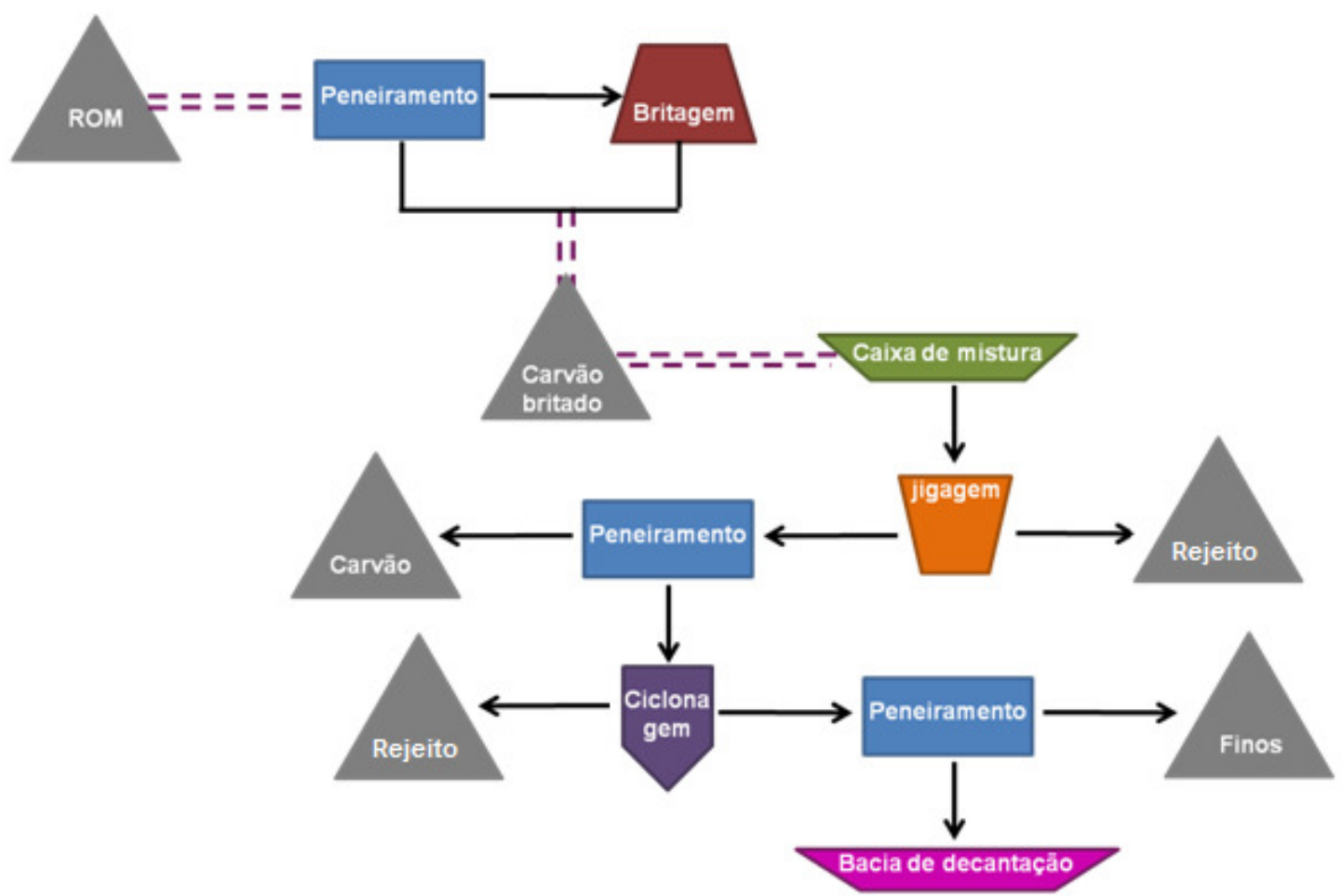

Figura 7 - Fluxograma esquemático do beneficiamento do carvão.

A presença de sedimentos como folhelhos, siltitos e argilitos e também de pirita faz com que seja necessário o beneficiamento do minério bruto para então se obter carvão energético e metalúrgico, além de outros produtos (Figura 8). 


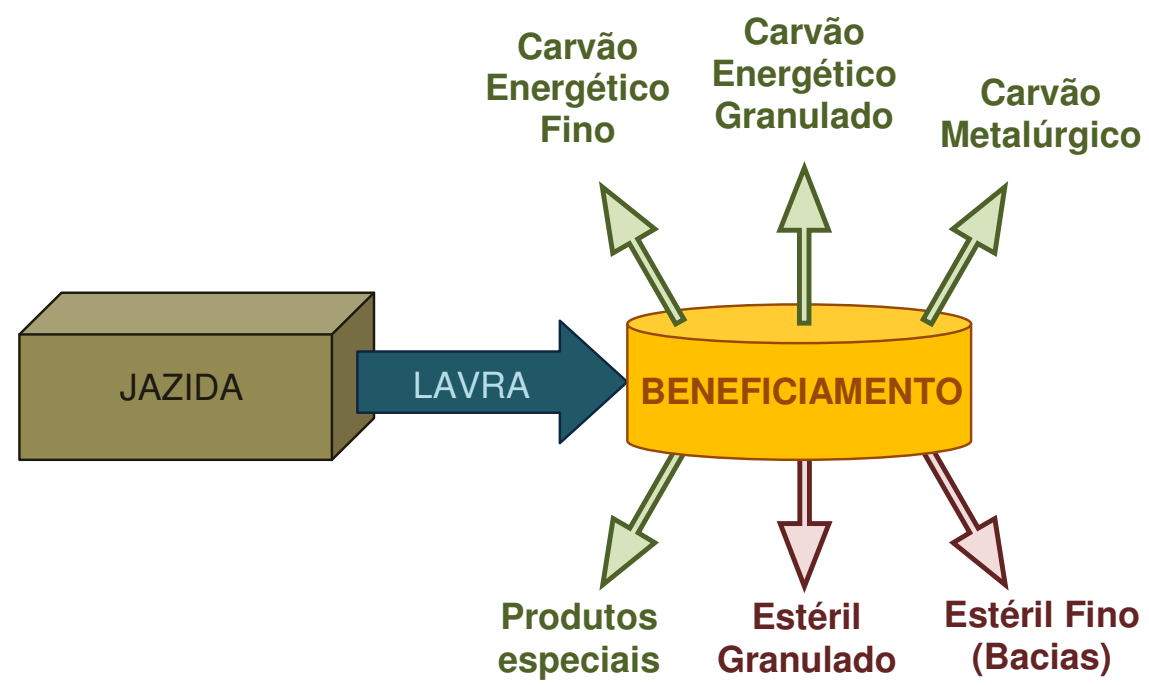

Figura 8 - Diagrama esquemático dos produtos de beneficiamento do carvão (adaptado de SCHNEIDER, 2008)

A mineração do carvão envolve processos impactantes ao meio ambiente, na Figura 9, é apresentada a cadeia desses impactos ambientais.

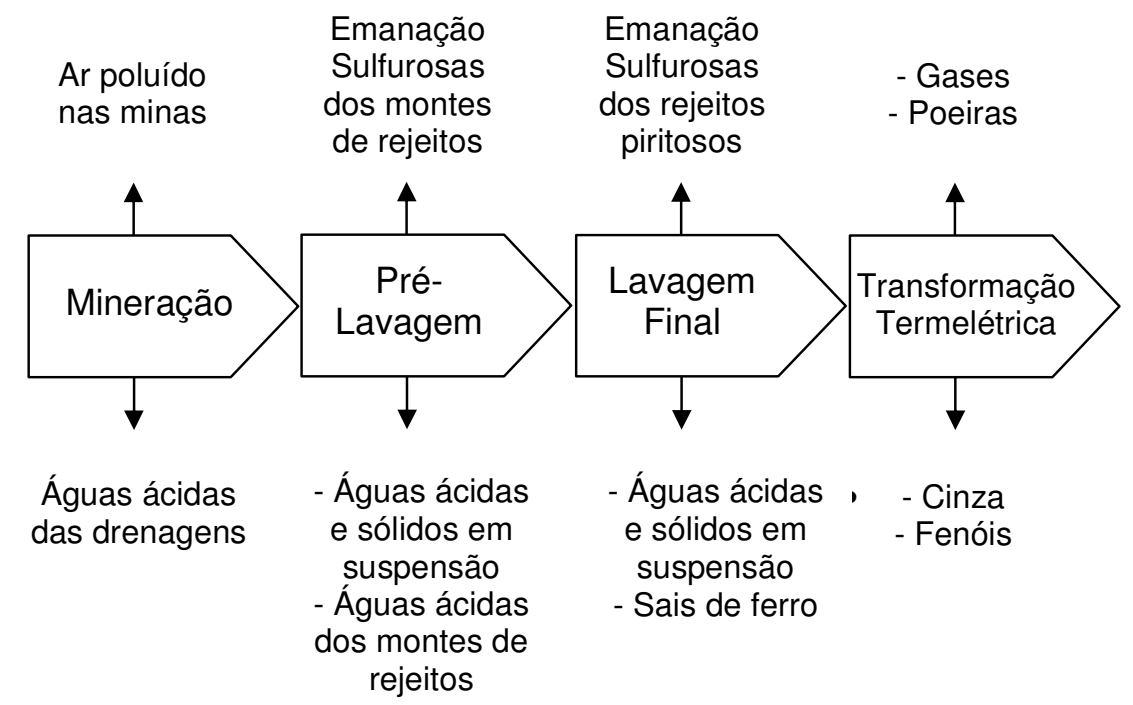

Figura 9 - Cadeia de impactos ambientais na mineração de carvão (adaptado de de LUCA, 2003)

A disposição dos resíduos gerados pela atividade de mineração é também parte do processo industrial, uma vez que estes resíduos constituem a principal fonte de acidez presente nas drenagens ácidas (SCHNEIDER, 2008). 


\subsubsection{Conceito e problemas da DAM}

Um dos principais impactos causados pela atividade mineradora é a poluição hídrica pela drenagem ácida de minas (DAM). Os problemas ambientais estão relacionados com os valores de $\mathrm{pH}$, geralmente, abaixo de 3 e a diversidade de metais dissolvidos (como ferro, alumínio, manganês, e traços de chumbo, cobre e zinco) (WEl et al., 2008), com concentrações que podem variar de 100 a $300 \mathrm{mg}^{-L^{-1}}$ (FARFAN, BARBOSA \& SOUZA, 2004).

A DAM é formada através da oxidação de minerais sulfetados, principalmente pirita $\left(\mathrm{FeS}_{2}\right)$, e tem capacidade de lixiviação de elementos presentes no minério e nas rochas circundantes à área minerada (CAMPANER \& SILVA, 2009).

Segundo Gaikwad \& Gupta (2008), quando a pirita entra em contato com água e oxigênio, reações de oxidação e hidrólise produzem sulfato $\left(\mathrm{SO}_{4}{ }^{2-}\right)$ e íons livre de hidrogênio $\left(\mathrm{H}^{+}\right)$, acidificando ainda mais o meio. A combinação do $\mathrm{pH}$ e das concentrações de metais associadas com a DAM podem ter efeitos toxicológicos nos ecossistemas aquáticos, como mortalidade, disfunções no crescimento e nas taxas de reprodução, deformidades e lesões (LEWIS \& CLARK, 1996).

Para Borma \& Soares (2002), a formação significativa de DAM ocorre quando há $\mathrm{o}$ atendimento de três premissas, no que tange:

- A mineralogia do substrato o resíduo deve conter quantidade de sulfetos superior a dos álcalis presentes no meio;

- As características da lavra e granulometria do substrato: a permeabilidade do resíduo deve ser tal que o oxigênio e a água sejam capaz de infiltrar;

- As condições ambientais: o resíduo deve estar em ambiente úmido ou exposto às águas de modo que a água da chuva seja capaz de percolá-lo ou às águas circundantes de transportá-lo ao meio ambiente.

Kontopoulos (1998) explica que as reações envolvidas na formação da DAM se dão por processos químicos e biológicos, originando-se da exposição de minerais sulfetados presentes em rochas e expostos à ação combinada de água e oxigênio atmosférico, por dois mecanismos, o mecanismo direto que ocorre nos estágios iniciais de oxidação da pirita (por exemplo), representado pela Equação 1, e o mecanismo indireto que ocorre nos estágios mais avançados do processo de acordo com as Equações 2 e 3. 


$$
\begin{aligned}
& 2 \mathrm{FeS}_{2}(\mathrm{~s})+7 \mathrm{O}_{2}+2 \mathrm{H}_{2} \mathrm{O} \rightarrow 2 \mathrm{Fe}^{2+}+4 \mathrm{H}^{+}+4 \mathrm{SO}_{4}{ }^{2-} \\
& \mathrm{FeS}_{2}(\mathrm{~s})+14 \mathrm{Fe}^{3+}+8 \mathrm{H}_{2} \mathrm{O} \rightarrow 15 \mathrm{Fe}^{2+}+2 \mathrm{SO}_{4}{ }^{2-}+16 \mathrm{H}^{+} \\
& 4 \mathrm{Fe}^{2+}+\mathrm{O}_{2}(\mathrm{aq})+4 \mathrm{H}^{+} \rightarrow 4 \mathrm{Fe}^{3+}+2 \mathrm{H}_{2} \mathrm{O}
\end{aligned}
$$

(via ação bacteriana)

Vale ressaltar que a reação (3) ocorre somente em pH inferior a 3,0 e se dá pela ação de bactérias acidofílicas (Thiobacillus spp.) que convertem o $\mathrm{Fe}^{2+}$ a $\mathrm{Fe}^{3+}$, retroalimentando a reação (2) em um processo autocatalítico (KONTOPOULOS, 1998). Em sistemas abióticos a oxidação direta é excessivamente lenta (ROSE \& GHASZI, 1998), uma vez que em pH menor do que 5 a oxidação do $\mathrm{Fe}^{2+}$ a $\mathrm{Fe}^{3+}$ é branda (SINGER \& STUMM, 1970).

Além do processo geoquímico supracitado, há outros processos associados à geração da DAM. Os principais são apresentados na Figura 10 (BORMA \& SOARES).

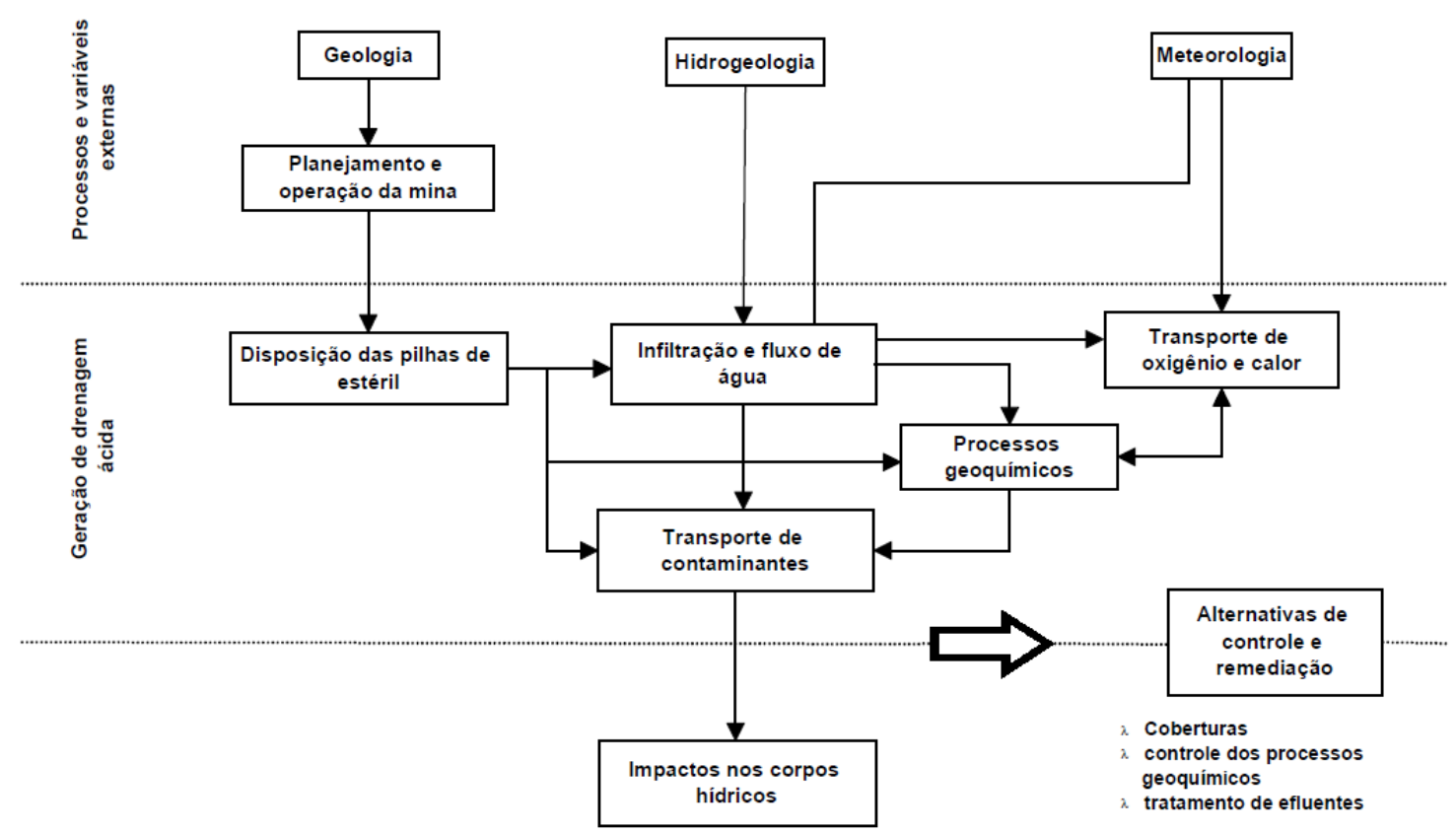

Figura 10 - Principais processos associados à geração de drenagens ácidas (BORMA \& SOARES, 2002).

Além da pirita, outros minerais sulfetados podem ser encontrados em rejeitos de mineração, como: marcasita $\left(\mathrm{FeS}_{2}\right)$, calcopirita $\left(\mathrm{CuFeS}_{2}\right)$, calcosita $\left(\mathrm{Cu}_{2} \mathrm{~S}\right)$, 
esfalerita $(\mathrm{ZnS})$, galena (PbS), millerita (NiS), pirrotita $\left(\mathrm{Fe}_{\mathrm{x}} \mathrm{S}_{\mathrm{x}}\right.$ onde: $\left.0<\mathrm{x}>0,2\right)$ ), arsenopirita $\left(\mathrm{FeAsS}_{2}\right.$ ), e cinabre (HgS) (FERGUSON \& ERICKSON, 1998 apud EPA, 1994). Dependendo dos minérios e das rochas circundantes a área de mineração e de percolação, a DAM pode apresentar diferentes características (Tabela 3) FARFAN, BARBOSA FILHO \& de SOUZA, 2004).

Tabela 3 - Características típicas da drenagem ácida de minas. (adaptado de FARFAN, BARBOSA FILHO \& de SOUZA, 2004)

\begin{tabular}{|c|c|c|c|}
\hline Propriedades & $\begin{array}{l}\text { Espécies químicas } \\
\text { típicas associadas }\end{array}$ & $\begin{array}{c}\text { Faixa de } \\
\text { concentração }\end{array}$ & Impacto \\
\hline $\mathrm{pH}$ & $\mathrm{H}_{2} \mathrm{SO}_{4}$ & $2-4$ & $\begin{array}{l}\text { - Mobilização de íons } \\
\text { metálicos. }\end{array}$ \\
\hline Ferro & $\begin{array}{c}\mathrm{Fe}^{2+}, \mathrm{Fe}^{3+}, \mathrm{Fe}_{2} \mathrm{O}_{3} \mathrm{e} \\
\text { hidróxidos }\end{array}$ & $\begin{array}{c}100-3.000 \\
\left(\mathrm{mg} \cdot \mathrm{L}^{-1}\right)\end{array}$ & $\begin{array}{l}\text { - Descoloração e turbidez nas } \\
\text { águas; } \\
\text { - Incremento do pH; } \\
\text { - Precipitação do } \mathrm{Fe}^{2+} \text {. }\end{array}$ \\
\hline $\begin{array}{c}\text { Metais } \\
\text { pesados }\end{array}$ & $\begin{array}{c}\mathrm{Cu}, \mathrm{Mg}, \mathrm{Zn}, \mathrm{Cd} \\
\mathrm{Hg}, \mathrm{Pb}, \mathrm{As}\end{array}$ & $\begin{array}{l}1-200 \\
\left(\mathrm{mg} \cdot \mathrm{L}^{-1}\right)\end{array}$ & $\begin{array}{l}\text { - Redução da flora e fauna } \\
\text { aquática; } \\
\text { - Bioacumulação; } \\
\text { - Redução da qualidade da água } \\
\text { potável de abastecimento. }\end{array}$ \\
\hline Sólidos totais & $\mathrm{Ca}, \mathrm{Mn}, \mathrm{Al}, \mathrm{SO}_{4}$ & $\begin{array}{c}100-30.000 \\
\left(\mathrm{mg} \cdot \mathrm{L}^{-1}\right)\end{array}$ & $\begin{array}{l}\text { - Redução da qualidade da } \\
\text { água de abastecimento }\end{array}$ \\
\hline
\end{tabular}

Na Tabela 3 também estão relacionados alguns dos impactos ambientais que podem vir a ser causado pelo DAM (FARFAN, BARBOSA FILHO \& de SOUZA, 2004).

De acordo com Vaz (2003), dois terços da malha hidrográfica da região de Criciúma estão comprometidos. Os rios da região apresentam valores de $\mathrm{pH}$ abaixo de 3 e elevados teores de sulfatos de ferro, além disso há locais assoreados pela deposição de finos e ultrafinos do carvão, com acentuada turbidez e concentrações de sólidos sedimentáveis. 
Ainda segundo o autor supracitado, os rejeitos piritosos quando abandonados comprometem áreas superiores a 5.000ha. na região carbonífera e a lixiviação destas pilhas contribui para a acidificação do solo e das águas superficiais.

Nas Figuras 11 e 12 podem-se visualizar, respectivamente, os impactos gerados pela DAM no rio Sangão e os rejeitos oriundos da mineração/beneficiamento do carvão expostos ao meio ambiente, ambos em Criciúma - SC.

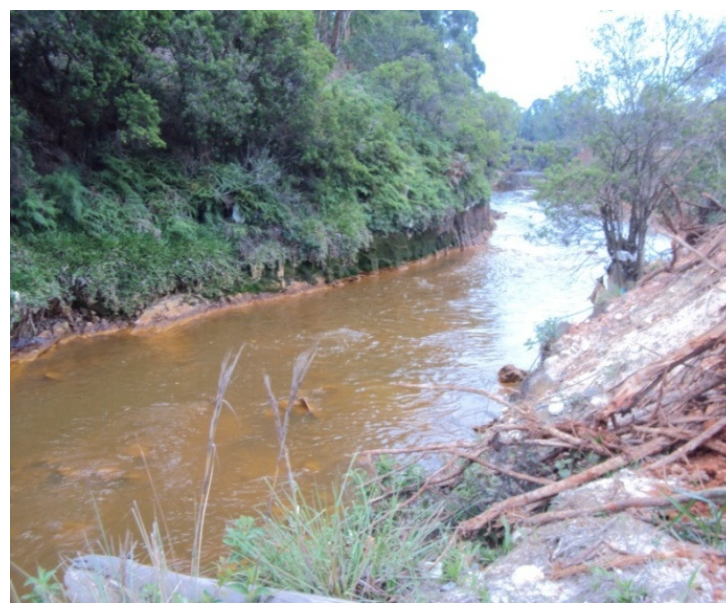

Figura 11 - Fotografia Rio Sangão, Criciúma - SC

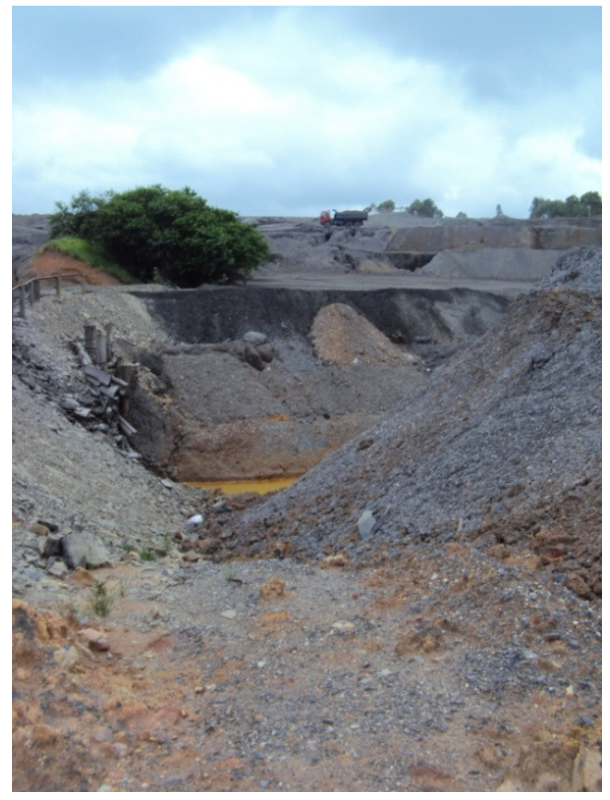

Figura 12 - Fotografia Pilhas de Rejeitos, Criciúma - SC

\subsubsection{Toxicologia dos metais}

A exposição ocupacional à metais na mineração e na manufatura está associada com intoxicação aguda e crônica, bem como com a carcinogênese (KANE KUMAR, 2005). Visto que a composição da DAM depende de vários fatores, fez-se uma breve revisão sobre os principais metais presentes em sua composição.

- Alumínio

É um metal não essencial ao organismo humano (SARI \& TUZEN, 2009) e seu acúmulo pode aumentar os riscos de doenças neurológicas e ósseas como 
Alzheimer, Parkinson, encefalopatia, demência entre outros (SHOKROLLAHI et al., 2008).

Concentrações acima de $0,5 \mathrm{mg} \cdot \mathrm{L}^{-1}$ combinadas com $\mathrm{pH}$ menores que 5,5 podem levar à morte peixes e macroinvertebrados (SCHNEIDER, 2006).

- Cádmio

Além de ser um elemento não-essencial para os organismos é considerado um dos metais mais tóxicos (STROBEL et al., 2001). Os efeitos agudos são irritação e edema pulmonar já a intoxicação crônica afeta os rins (KANE \& KUMAR, 2005).

- Chumbo

De um modo geral, os compostos de chumbo são nocivos para os animais e sua toxicidade relaciona-se com seus múltiplos efeitos bioquímicos (KANE \& KUMAR, 2005). Porém, o chumbo e o sulfato de chumbo são muito pouco absorvidos, sendo considerados praticamente inócuos. No entanto, alguns dos seus sais solúveis, como cloreto, nitrato e acetato, são venenos ativos (LEMOS, 2008).

O chumbo contribui para muitos efeitos crônicos como danos ao sistema nervoso central e periférico que causam cefaléia, tonteira, deficiência de memória e decréscimo da velocidade da condução nervosa. Alterações no sangue também podem ocorrer e assim como anemia, cólicas, insônia, fadiga, deficiência cognitiva e toxicidade renal (KANE \& KUMAR, 2005).

- Cobre

Este elemento desempenha um papel importante no metabolismo animal, a falta de cobre na dieta animal pode provocar anemia, diarréia e distúrbios nervosos. Por outro lado, a ingestão excessiva de compostos como o sulfato de cobre pode causar vômitos, cãibras, convulsões ou mesmo a morte (LEMOS, 2008).

- Cromo

O cromo é um metal essencial para os organismos vivos (CEFALU \& HU, 2004), no entanto apresenta elevada toxicidade que o torna um metal perigoso mesmo em concentrações muito baixas (20mg.L $\mathrm{L}^{-1}$ ) (CHEUNG \& GU, 2003).

$\mathrm{Na}$ natureza, o cromo ocorre em dois estados de oxidação principais: $\mathrm{Cr}$ (III) e $\mathrm{Cr}(\mathrm{VI})$. O Cr ( $\mathrm{VI})$ é prontamente absorvido através das membranas celulares e é reduzido a $\mathrm{Cr}$ (III) que leva a liberação de radicais livres capazes de causar alterações no DNA, podendo induzir ao aparecimento de câncer de pulmão e da cavidade nasal (KANE \& KUMAR, 2005). 
- Ferro

Possui função biológica no organismo no transporte de oxigênio e elétrons da mitocôndria, porém o excesso de ferro no organismo cria depósitos do metal, que podem levar à formação de lesão hepática (cirrose), diabetes mellitus bem como à pigmentação da pele (LEMOS, 2008).

- Manganês

É um elemento essencial à vida animal e vegetal, que faz parte da constituição de certas enzimas e, provavelmente, condiciona a utilização de vitaminas (B1). A sua deficiência provoca a diminuição de clorofila nas plantas (que adquirem um aspecto amarelado) e perturbações nos tecidos ósseos dos animais. Os compostos de manganês, genericamente, não são considerados tóxicos. Contudo, as propriedades oxidantes de alguns permanganatos podem causar irritação da pele e a inalação dos seus vapores pode ser bastante prejudicial (LEMOS, 2008).

Em efluentes e corpos hídricos, se presente na forma insolúvel pode acarretar redução na diversidade de espécies de macroinvertebrados (SCHNEIDER, 2006)

- Níquel

Compostos de partículas de níquel são carcinogênicos e alcançam as célulasalvo através da fagocitose e liberação intracelular de seus íons, com isso podem causar câncer do pulmão e seios nasais. A exposição tópica ao níquel também causa, freqüentemente, dermatite de contato (KANE \& KUMAR, 2005)

- Zinco

É considerado um elemento essencial para a saúde do ser humano participando de diversos processos metabólicos. Contudo, a constante acumulação deste metal no corpo pode gerar toxicidade gastrointestinal (WALSH et al., 1994). $\mathrm{Na}$ sua forma metálica, tem uma limitada biodisponibilidade e não apresenta nenhum risco ecológico. Entretanto, o zinco pode reagir com outras substâncias químicas, como ácidos e oxigênio, para formarem compostos que podem se tornar tóxicos (RADHIKA, SUBRAMANIAN \& NATARAJAN, 2006). Além disso, o zinco pode apresentar sérios riscos à saúde humana se ingerido além do recomendado como: náuseas, vômito, problemas gastrointestinais, letargia e fadiga (FOSMIRE, 1990). 


\subsubsection{Tratamentos}

O tratamento de efluentes contaminados com metais pode ser feito através de processos que incluam neutralização, técnicas eletroquímicas, precipitação química, oxi-redução, processos de troca-iônica utilizando-se solventes orgânicos ou resinas sintéticas, carvão ativado e tecnologias com emprego de membranas (VOLESKY, 1988).

De acordo com Gaikwad \& Gupta (2008), os tratamentos da drenagem ácida de minas podem ser divididos em duas grandes classes de metodologias:

Tratamento passivo: reações naturais, químicas e biológicas, que ocorrem em um reator químico-microbiológico controlado.

Tratamento ativo: adição mecânica de álcalis para aumentar o pH e precipitar os metais.

O tratamento típico é a neutralização da DAM com cal ou agentes similares, porém esse processo gera resíduos (lamas) provenientes da precipitação de hidróxidos dos metais (CAMPANER \& SILVA, 2009; FENG, ALDRICH \& TAN, 2000; JENKE \& DIEBOLD, 1983). Segundo Neto et al., (2005), o lodo resultante da neutralização da DAM é classificado conforme a NBR 10004/2004, como Resíduo Não Inerte - Classe II A. A sua disposição em aterros exige a impermeabilização com argila e geomembrana de PEAD (polietileno de alta densidade), sistema de drenagem e tratamento dos efluentes e um programa de monitoramento com custos elevados como qualquer resíduo classe II A.

Um tratamento alternativo é a precipitação seletiva, nesse processo controla-se o pH de forma a precipitar-se somente o metal desejado em cada faixa de $\mathrm{pH}$. Os metais então podem ser recuperados e comercializados (WEI et al., 2005).

Além dos tratamentos supracitados, outras técnicas têm sido estudadas para o tratamento de efluentes de uma forma geral: Gao et al. (1995) estudaram a remoção de zinco, cádmio, cobre e chumbo através de troca iônica, já Xie et al. (1996) aliaram a extração iônica a biossorção e trabalhou com metais como ouro, alumínio, cádmio, cobre, cromo, cobre, mercúrio, níquel, chumbo, selênio e zinco obtendo bons resultados com remoção superior a 85\%. Utgikar et al. (2000) também 
pesquisaram a biossorção de zinco e cobre em concentrações de 700mg/l e conseguiu captar $74 \mathrm{mg}$ de metais.

Wei et al. (2005), Matlock et al. (2002) e Feng et al. (2000), estudaram com sucesso a precipitação de ferro, manganês e alumínio. Já Costa et al. (2005), utilizando resíduos da fabricação de vinho removeram $91 \%$ de $\mathrm{Fe}$, e $97 \%$ de $\mathrm{Zn}$ e Cu. Elliott, Ragusa, \& Catcheside (1998), utilizando bacteria sulfato redutora em um sistema de remediação de DAM, removeram $14 \%$ de sulfato.

Remoções acima de $85 \%$ para ferro, alumínio e níquel foram alcançadas por Bernier et al. (2005) com tratamento passivo. Zagury et al. (2006), utilizando tratamento passivo biológico, removeram $94 \%$ ou mais de ferro, manganês, cádmio, níquel e zinco.

A utilização de algas como biomassa para adsorção de zinco, cobre e cádmio foi estudada por Rose et al. (1998) e os resultados obtidos variam de 60 a $85 \%$ de remoção dos metais. Chartrand et al. (2003) trabalharam com a remoção de ferro e cobre através de tratamento eletroquímico e obtiveram bons resultados, entre 80 e $90 \%$, de capitação.

Outros métodos de tratamento foram estudados como adsorção (ERDEM et al., 2004), tratamento anaeróbico e atividade microbiana (TSUKAMOTO, KILLION \& MILLER, 2004), utilização de resíduo orgânico (CHANG et al., 2000), reator anaeróbico de fluxo (LA et al., 2003), reator de leito fluidizado (UMITA, et al., 1996) entre outros.

As tecnologias tradicionais para a remoção de metais pesados como precipitação química, troca iônica, membranas e extração por solvente, são normalmente ineficientes e/ou muito caras (CAYLLAHUA \& TOREM, 2008). Zouboulis, Loukidou \& Matis (2004) compilaram as vantagens e desvantagens das metodologias de tratamento de efluentes convencionais e os resultados são apresentados na Tabela 4. 
Tabela 4 - Tecnologias convencionais para remoção de metais de efluentes (adaptado de ZOUBOULIS, LOUKIDOU \& MATIS, 2004).

\begin{tabular}{|c|c|c|}
\hline Método & Desvantagens & Vantagens \\
\hline $\begin{array}{l}\text { Precipitação } \\
\text { química }\end{array}$ & $\begin{array}{l}\text {-Dificuldade de separação } \\
\text {-Disposição da lama resultante } \\
\text {-Baixa eficiência }\end{array}$ & $\begin{array}{l}\text {-Simples } \\
\text {-Relativamente barato }\end{array}$ \\
\hline $\begin{array}{l}\text { Tratamento } \\
\text { eletroquímico }\end{array}$ & $\begin{array}{l}\text {-Altas concentrações de metais } \\
\text {-Sensível a presença de compostos } \\
\text { interferentes }\end{array}$ & -Recuperação do metal \\
\hline $\begin{array}{l}\text { Osmose } \\
\text { reversa }\end{array}$ & $\begin{array}{l}\text {-Altas pressões } \\
\text {-Caro } \\
\text {-Saturação da membrana }\end{array}$ & $\begin{array}{l}\text {-Efluente puro passível de } \\
\text { reciclagem }\end{array}$ \\
\hline $\begin{array}{c}\text { Extração } \\
\text { iônica }\end{array}$ & $\begin{array}{l}\text {-Alto custo das resinas } \\
\text {-Sensível a presença de partículas } \\
\text { interferentes }\end{array}$ & $\begin{array}{l}\text {-Efetivo } \\
\text {-Recuperação do metal }\end{array}$ \\
\hline Adsorção & -Baixa eficiente para alguns metais & $\begin{array}{l}\text {-Adsorventes } \\
\text { convencionais }\end{array}$ \\
\hline
\end{tabular}

Novas tecnologias que reduzam as concentrações de metais pesados do meio ambiente a níveis aceitáveis com custos acessíveis foram pesquisadas (CAYLLAHUA \& TOREM, 2008). A busca por processos bissortivos específicos para remoção de metais de efluentes de atividades de mineração tem sido feita objetivando de um lado a descontaminação do efluente a ser lançado no ambiente e de outro lado, a recuperação desses metais (GARCIA Jr, 1997). 


\subsection{Biossorção}

A ativa participação dos microrganismos nos processos geoquímicos permitiu o desenvolvimento de processos tecnológicos, englobados sobre o nome genérico de bio-hidrometalurgia (GARCIA Jr, 1997). Entre os processos associados à biohidrometalurgia destaca-se neste trabalho a biossorção.

Biossorção é definido com um processo de concentração de sorbato em um sorvente de origem biológica (CHOJNACKA, 2010).

O processo de biossorção está fundamentado na capacidade de alguns tipos de biomassa de concentrar e ligar metais de soluções aquosas diluídas através de seu envoltório celular (VÁSQUEZ, 2005). Esse método pode estar relacionado com o metabolismo da célula ou com processos de adsorção física ou química na parede celular da biomassa. (CUI \& ZHANG, 2008).

Os processos biossortivos são geralmente rápidos e viáveis para a extração de íons metálicos da água e podem ser seletivos, além de dispensarem a adição de reagentes (BUENO, 2007). Quando comparados com outros processos para tratamento de efluentes a biossorção apresentam as seguintes vantagens: custo operacional, minimização do volume de lama química e/ou biológica para ser disposta, eficiência no tratamento de efluentes diluídos, possibilidade de reutilização do biossorvente e recuperação dos metais, não requerem nutrientes quando a biomassa se encontra inativa e são ambientalmente corretos (BUENO, 2007; CAYLLAHUA \& TOREM, 2008; CHOJNACKA, 2010).

É possível definir ainda biossorção como um termo coletivo para um número de processos passivos e mecanismos físico-químicos que podem incluir: extração iônica, coordenação, complexação, adsorção e quelação entre os íons metálicos e ligantes (FEBRIANTO et al., 2009; BUENO, 2007; KURNIAWAN, CHAN \& LO, 2006; VOLESKY, 1990).

Os processos biossortivos supracitados ocorrem como resultado do gradiente de concentração e difusão através da parede celular e membranas do biossorvente (VOLESKY, 1990). Inicialmente os íons metálicos se difundem da solução concentrada (bulk) à superfície da parede celular onde eles se ligam aos sítios ativos constituídos pela presença de grupos funcionais, conforme Figura 13 (BUENO, 2007). 


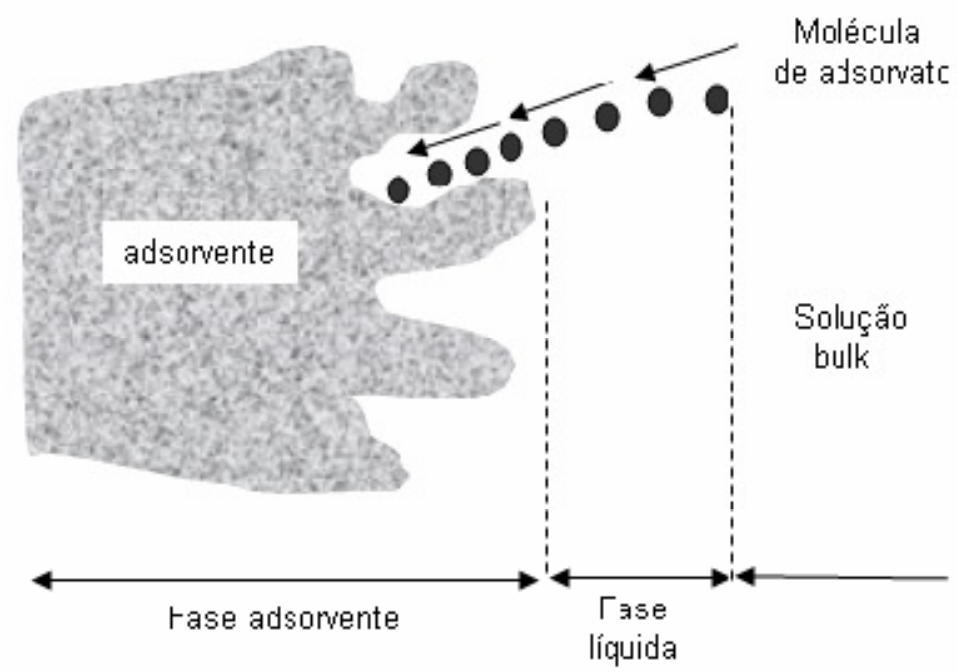

Figura 13 - Adsorção de moléculas na superfície do adsorvente (BUENO, 2007).

Outros mecanismos de remoção do metal dependem do metabolismo e incluem precipitação como sulfetos ou fostatos metálicos, seqüestro por proteínas, peptídeos ou sideróforos, transporte e compartimentação interna (WHITE, WILKINSONAND \& GADD, 1995).

Os mecanismos de biossorção foram classificados segundo Veglio e Beolchini (1997) de acordo com sua dependência ou não do metabolismo celular (Figura 14) e conforme a localização do metal removido da solução (Figura 15). Nos dois casos os mecanismos podem ocorrer isoladamente ou simultaneamente com outros mecanismos de biossorção.

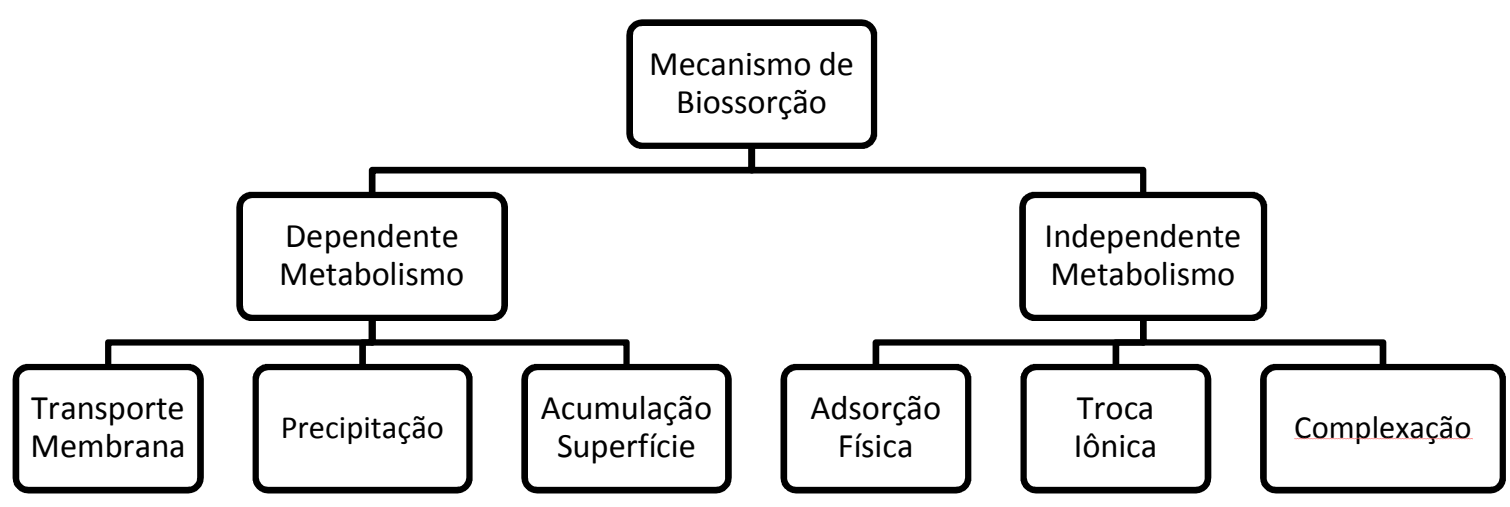

Figura 14 - Classificação do mecanismo de biossorção: dependência do metabolismo celular (adaptado de VEGLIO \& BEOLCHINI, 1997). 
A desvantagem do mecanismo de biossorção dependente do metabolismo celular é a demora na resposta, pois é necessário um tempo para a reação do metal com o microrganismo (VEGLIO \& BEOLCHINI, 1997).

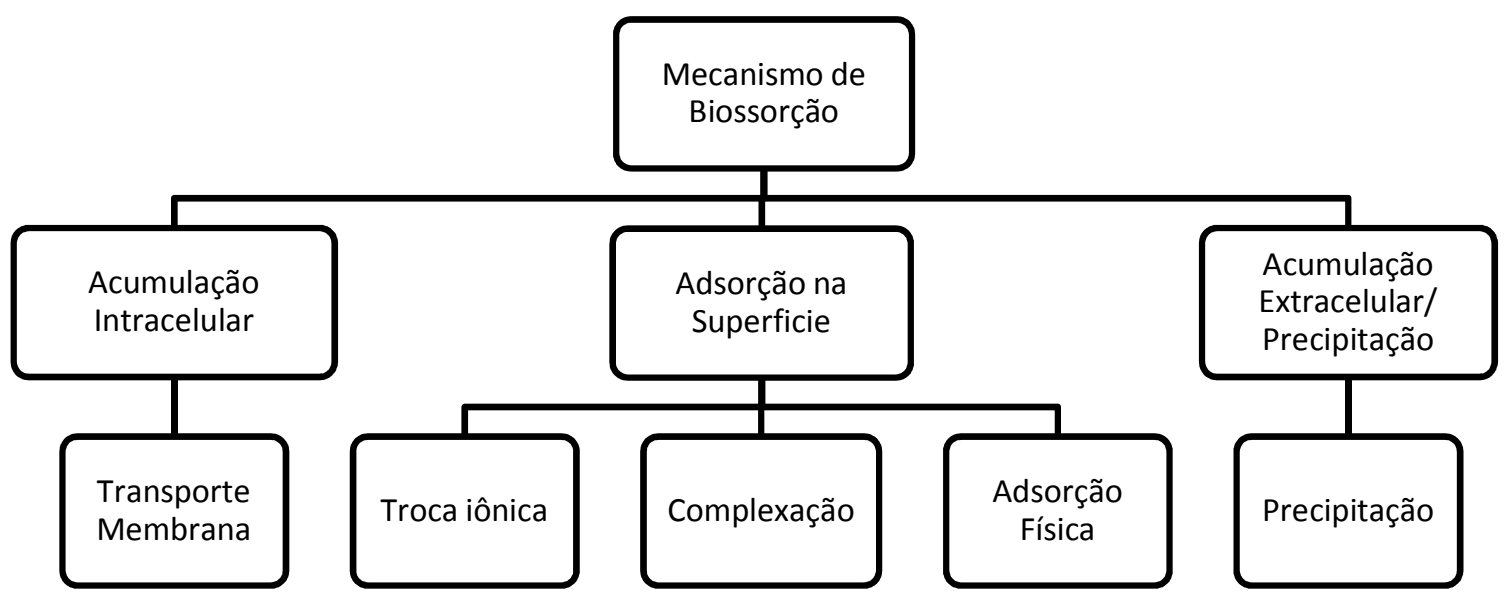

Figura 15 - Classificação do mecanismo de biossorção: sítio onde o metal é removido (adaptado de VEGLIO \& BEOLCHINI, 1997).

Quando o mecanismo de biossorção não dependente do metabolismo celular o processo ocorre através da interação físico-química entre o metal e os grupos funcionais da superfície celular (VÁSQUEZ, 2005).

O transporte através da membrana celular é um mecanismo de difícil identificação, pois quando o metal é transportado através da membrana pode sofrer o mesmo processo que ocorre com os metais essenciais (VÁSQUEZ, 2005).

O processo mais comum é a adsorção, no qual substâncias solúveis presentes em solução são captadas em uma interface, em outras palavras existe transferência seletiva de um ou mais solutos de uma fase liquida para uma fase sólida. (TOBIN, WHITE \& GADD, 1994). Vásquez (2005) ressalta que a ocorrência da adsorção física só acontece se sítios ativos estiverem disponíveis para aceitar os íons metálicos.

Resultados obtidos em pesquisas de biossorção evidenciam que a troca iônica é o principal mecanismo de biossorção de metais (KRATOCHVIL \& VOLESKY, 1998).

Ao estudar a relação entre a morfologia microbiana e seu efeito na acumulação dos metais, Beveridge (1989) descreveu que a acumulação superficial ocorre através de reações de complexação e troca-iônica com os constituintes da estrutura externa dos biossorventes. 
A complexação e a precipitação são mecanismos que envolvem a coordenação de um íon metálico com um grupo funcional da parede celular formando um complexo na superfície da célula após a interação. Este fenômeno pode trocar os estados de oxidação dos metais para torná-los tanto solúveis como insolúveis (VASQUEZ, 2005).

Segundo Westall (1987) apud Bueno (2007), a complexação tem um papel importante na interação metal-ligante uma vez que, um complexo ou composto de coordenação é uma molécula poliatômica a qual consiste de um ou mais átomos centrais, usualmente cátions metálicos, rodeados por ligantes que são adjuntos a estes. Os complexos podem ser neutros, positivamente ou negativamente carregados e o número de átomos de coordenação (no ligante) o qual está diretamente adjunto ao átomo central é chamado de número de coordenação e pode ser maior que a valência do átomo central, sendo que 4 e 6 são os números de coordenação mais comuns. Se um ligante é adjunto ao átomo central através de dois ou mais átomos de coordenação, então o complexo recebe o nome de quelato (DAVIS, VOLESKY \& MUCCI, 2003).

O mecanismo de quelação está baseado na existência de um agente quelante, composto que tem a facilidade de ter dois átomos diferentes coordenados com o íon metálico, que facilita a formação de um semi-anel capaz de seqüestrar o íon de interesse (VÁSQUEZ, 2005).

Já quando existe alguma variação nas condições ambientais próximas da superfície da biomassa e esta alteração gera variação no $\mathrm{pH}$, ocorre a microprecipitação (PINO, 2005). Pode-se definir microprecipitação como a deposição do material eletricamente neutro na superfície da biomassa. Essa reação não envolve necessariamente uma ligação entre a biomassa e a camada depositada e o processo é facilitado pela ligação inicial dos íons metálicos aos sítios ativos da biomassa, a qual serve como sítio de nucleação para precipitação adicional (MAYERS \& BEVERIDGE, 1999). Este processo não está limitado a uma monocamada ou à saturação dos sítios e as células podem acumular varias vezes seu peso seco em metal.

Garcia Jr. (1997) explica que o acúmulo de metal na superfície celular ocorre em dois estágios: primeiramente o metal liga-se somente aos sítios ativos 
disponíveis, porém após essa ligação estequiométrica os íons metálicos atuam como sítios de nucleação para a deposição de mais íons metálicos.

Desta forma a capacidade de adsorver metais, assim como o tempo de biossorção, dependem diretamente das características do revestimento celular de cada espécie (WHITE, WILKINSONAND \& GADD, 1995; BUENO, 2007).

A Figura 16 esquematiza alguns dos mecanismos de interação supracitados, entre os metais e as células dos microrganismos.

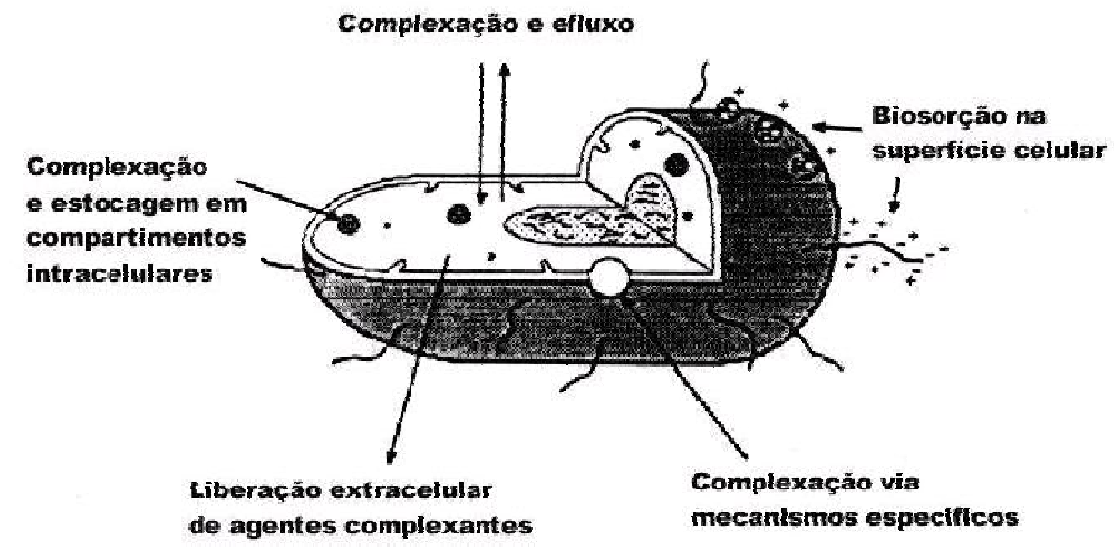

Figura 16 - Esquematização dos processos de interação entre metais e célula microbiana (adaptado de BIRCH \& BACHOFEN, 1990 apud BUENO, 2007).

\subsubsection{Biossorventes}

Estudos têm mostrado que muitos biomateriais (naturais ou modificados) podem ser utilizados como biossorventes de metais pesados entre eles algas, plantas aquáticas, fungos, bactérias e subprodutos agroindustriais (SCHNEIDER,1995).

A habilidade de captação dos metais pelos microrganismos esta associada com seus componentes celulares, sendo os principais água, sais inorgânicos e elementos minerais, proteínas, ácidos nucléicos, polissacarídeos e lipídeos (LEHNINGER et al., 1993). Além disso, a capacidade de uma biomassa em recuperar metais de efluentes depende de suas propriedades físicas, químicas e biológicas. (KRATOCHVIL \& VOLESKY, 1998).

Os polissacarídeos, as proteínas e os lipídeos presentes na parede celular da biomassa microbiana são os responsáveis pelos muitos grupos funcionais 
(carboxilas, fosfatos, hidroxilas, sulfatos e grupos amino) disponíveis para os íons metálicos ligarem-se (VÁSQUEZ, 2005; GREENE et al., 1987).

$\mathrm{Na}$ Tabela 5 estão presentes os diferentes grupos funcionais envolvidos na captação de metais da solução.

Tabela 5 - Grupos químicos de ligação envolvidos na biossorção (VOLESKY, 2007).

\begin{tabular}{|c|c|c|c|c|c|}
\hline $\begin{array}{l}\text { Grupo de } \\
\text { ligação }\end{array}$ & $\begin{array}{l}\text { Fórmula } \\
\text { estrutural }\end{array}$ & $\mathrm{pK}_{\mathrm{a}}$ & $\begin{array}{c}\text { Classificação } \\
\text { HSAB }\end{array}$ & $\begin{array}{l}\text { Átomo } \\
\text { ligante }\end{array}$ & $\begin{array}{l}\text { Biomoléculas } \\
\text { (ocorrência) }\end{array}$ \\
\hline Hidroxila & $\mathrm{R}-\mathrm{OH}$ & $9,5-13$ & Duro & $\mathrm{O}$ & $\begin{array}{c}\text { PS, AU, PSS, } \\
\text { AA }\end{array}$ \\
\hline $\begin{array}{l}\text { Carbonila } \\
\text { (cetona) }\end{array}$ & & - & Duro & $\mathrm{O}$ & LP \\
\hline Carboxila & & $1,7-4,7$ & Duro & $\mathrm{O}$ & $A U, A A$ \\
\hline $\begin{array}{c}\text { Sulfidrila } \\
\text { (tiol) }\end{array}$ & & $\begin{array}{l}8,3- \\
10,8\end{array}$ & Macio & $\mathrm{S}$ & AA \\
\hline Sulfonato & $\mathrm{R}-\mathrm{U}_{\mathrm{O}}^{\mathrm{S}}=\mathrm{O}$ & 1,3 & Duro & $\mathrm{O}$ & PSS \\
\hline Tioéter & & - & Macio & $S$ & $\mathrm{AA}$ \\
\hline Amina & $\mathrm{R}-\mathrm{NH}_{2}$ & $8-11$ & Intermediário & $\mathrm{N}$ & QTO, AA \\
\hline $\begin{array}{c}\text { Amina } \\
\text { secundária }\end{array}$ & & 13 & Intermediário & $\mathrm{N}$ & QTO, PG, LP \\
\hline Amida & & - & Intermediário & $\mathrm{N}$ & $\mathrm{AA}$ \\
\hline Imina & $\mathrm{R}=\mathrm{NH}$ & $\begin{array}{c}11,6- \\
12,6\end{array}$ & Intermediário & $\mathrm{N}$ & AA \\
\hline
\end{tabular}




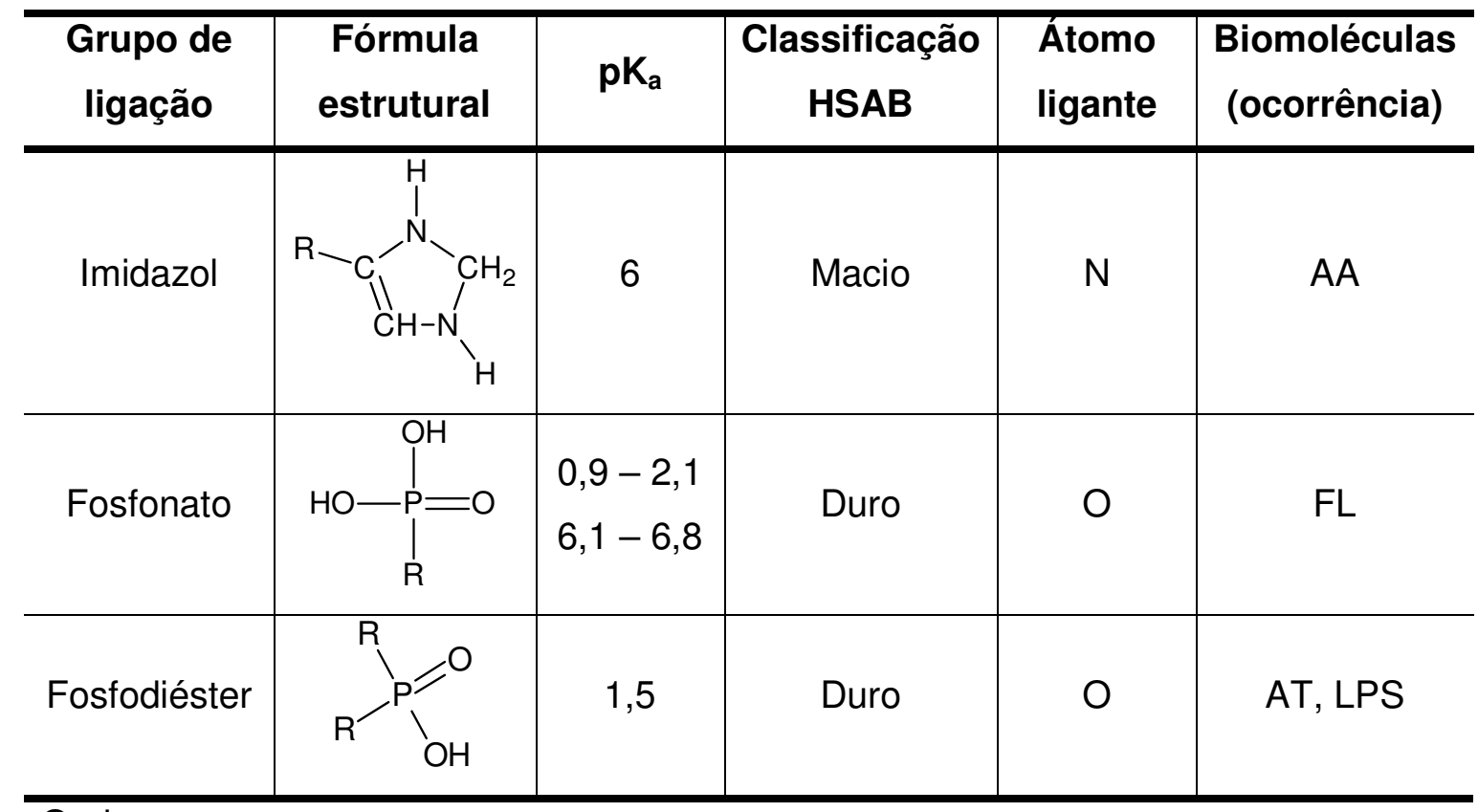

Onde:

$\mathrm{AA}$ = aminoácido; $\mathrm{AT}$ = ácido teicóico; $\mathrm{AU}$ = ácido urônico; $\mathrm{FL}=$ fosfolipídio; $\mathrm{LP}=$ ligação peptídica; $\mathrm{LPS}=$ lipopolissacarídeo; $\mathrm{PS}=$ polissacarídeo; PSS = polissacarídeo sulfatado; PG = peptidoglicano; QTO = quitosano.

Um grupo ácido forte como o radical sulfonato está ionizado em qualquer valor de $\mathrm{pH}$ acima de 1 , fato que o torna pouco seletivo porém com poder de captação de cátions em praticamente qualquer $\mathrm{pH}$. Já grupos superficiais de ácidos fracos não estão ionizados quando o pH encontra-se abaixo do valor de dissociação e usualmente só exibem comportamento de troca-iônica máximo em valores acima do seu pK, um exemplo é a carboxila cujo pK é aproximadamente 4,7. Aminas primárias ou secundárias são radicais básicos fracos e não se dissociam em água em pH maiores do que seu pK, geralmente entre 7 e 9 (SCHNEIDER, 1995).

As diferentes características apresentadas por cada microrganismo dependem dos tipos de proteínas, grupos aminas, ácidos orgânicos e polissacarídeos que a célula possui em sua parede. Essas características aliadas à espécie e as condições da cultura são responsáveis por atribuir carga elétrica positiva ou negativa à superfície do microrganismo (CHOJNACKA, CHOJNACKI \& GÓRECKA, 2005; VÁSQUEZ, 2005).

Podemos perceber com clareza essas diferenças de composição da parede celular ao observar as Figuras 17 e 18, onde estão representados o esquema estrutural da parede celular de bactérias gram-positivas e gram-negativas, respectivamente. 


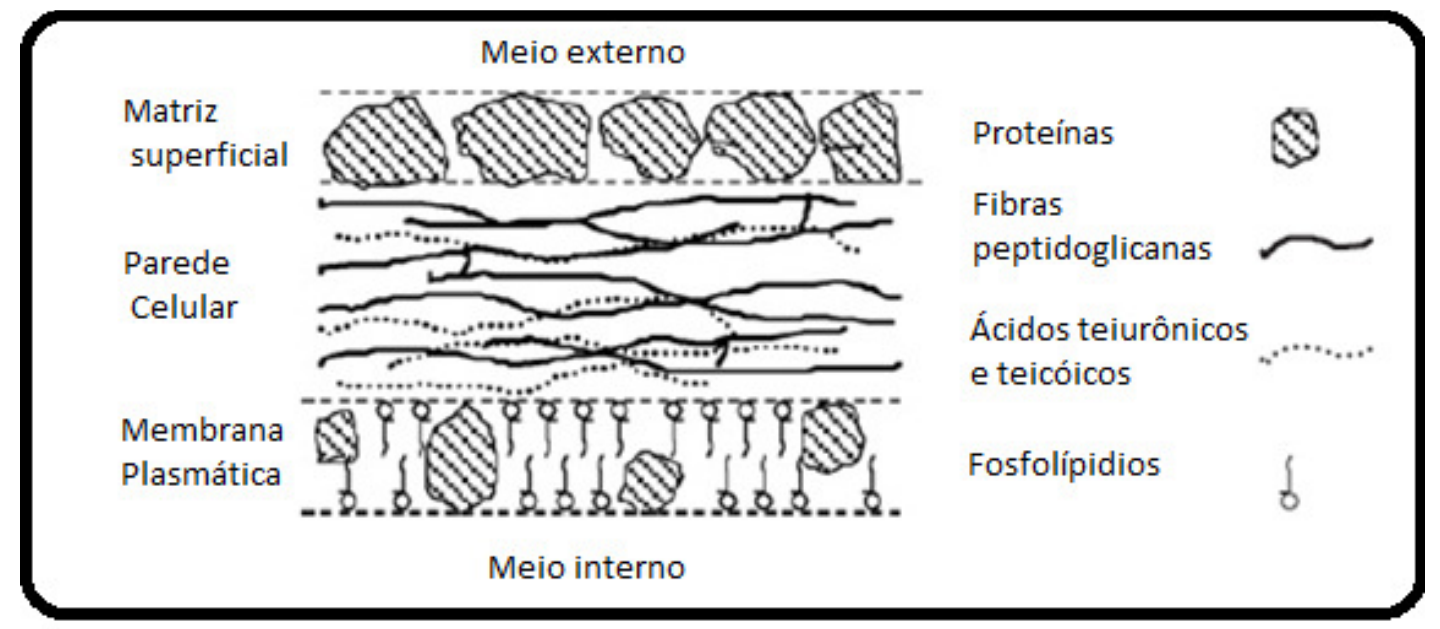

Figura 17 - Contorno esquemático da estrutura celular de bactérias gram-positivas (VOLESKY, 2007)

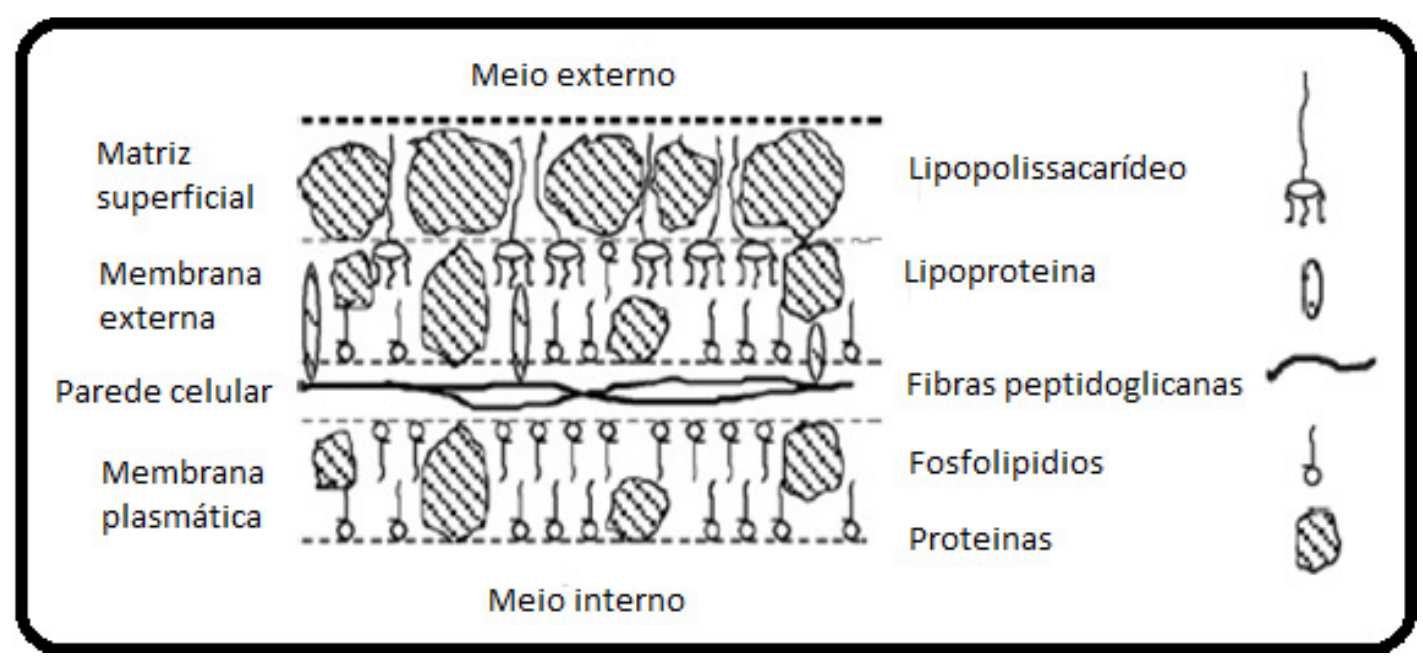

Figura 18 - Contorno esquemático da estrutura celular de bactérias gram-negativas (VOLESKY, 2007).

Biossorventes têm sido testados visando avaliar sua capacidade de remover metais sobre várias condições, sendo que as biomassas de origem microbiana têm tido um interesse particular

\subsubsection{Rhodococcus}


Segundo Viana (2007) e Goodfelow (1998) o gênero Rhodoccoccus foi descrito pela primeira vez por Zopf em 1891, sendo que em 1977 ocorreram modificações para acomodar algumas cepas que apresentavam diferenças dos gêneros previamente estabelecidos (BELL et al. , 1996).

Rhodococcus são bactérias pertencentes à classe dos actinomicetos (GYLES, et al. 2004), integrantes do grupo fenotípico Nocardioformes (BELL et al., 1998) que possuem aspectos morfológicos e de ciclo celular diferenciados dos demais organismos gram-positivos. Em geral, são aeróbios, contém ácidos micólicos na parede celular, não são móveis na fase vegetativa e apresentam pleomorfismo em alguma fase do ciclo celular, podendo formar filamentos (STACKEBRANDT et al., 1997).

Os membros do gênero Rhodococcus são gram-positivos (MIRIMANOFF \& WILKINSON, 2000), não esporulados (ALVAREZ et al, 2004), possuem um amplo espectro metabólico, com capacidade de degradar uma variedade de poluentes, como hidrocarbonetos, herbicidas e outros compostos xenobióticos (FINNERTY, 1992; BELL et al.,1998). Além disso, no seu ciclo de crescimento podem variar, morfologicamente, de cocos a pequenos bastonetes (FINNERTY, 1992)

$\mathrm{Na}$ Tabela 6 podem-se visualizar algumas das diferenças e semelhanças entre as seguintes espécies do gênero Rhodococcus: equi, fascians, marinonascens, opacus, rhodnii, e ruber.

Tabela 6 - Características de diversas espécies do gênero Rhodococcus (GOODFELLOW, 1998). 


\begin{tabular}{|c|c|c|c|c|c|c|}
\hline & R. equi & $\begin{array}{c}R . \\
\text { fascians }\end{array}$ & $\begin{array}{c}R . \\
\text { marino- } \\
\text { nascens }\end{array}$ & $\begin{array}{c}R . \\
\text { opacus }\end{array}$ & $\begin{array}{c}R . \\
\text { rhodnii }\end{array}$ & R. ruber \\
\hline $\begin{array}{l}\text { Seqüência } \\
\text { morfogenética }\end{array}$ & $\mathrm{R}-\mathrm{C}$ & $\mathrm{H}-\mathrm{R}-\mathrm{C}$ & $\mathrm{H}-\mathrm{R}-\mathrm{C}$ & $\mathrm{R}-\mathrm{C}$ & EB-R-C & $\mathrm{H}-\mathrm{R}-\mathrm{C}$ \\
\hline Colônias amarelas & - & + & - & - & - & - \\
\hline $\begin{array}{c}\text { Degradação de: } \\
\text { - Adenina }\end{array}$ & + & & - & ND & - & - \\
\hline - Tirosina & - & + & V & ND & - & - \\
\hline $\begin{array}{l}\text { Crescimento } \mathrm{c} / \\
\text { uma única fonte de } \\
\text { carbono }(1 \% \mathrm{p} / \mathrm{v}) \text { : }\end{array}$ & & & & & & \\
\hline - Celobiose & V & - & - & + & - & - \\
\hline - Galactose & - & + & - & & - & - \\
\hline - Inositol & + & - & + & + & - & - \\
\hline - Maltose & - & - & - & + & - & + \\
\hline - Manose & V & + & + & - & + & - \\
\hline - Manitol & + & + & + & ND & + & + \\
\hline - Ribose & + & + & - & + & - & - \\
\hline - Sorbitol & + & + & - & ND & + & + \\
\hline - Sacarose & + & + & + & + & - & + \\
\hline - Turanose & - & V & ND & + & - & - \\
\hline - Xilose & - & + & - & ND & + & - \\
\hline $\begin{array}{l}\text { Ácidos Micólicos } \\
\text { (№ de carbonos) }\end{array}$ & $30-38$ & $38-52$ & ND & $48-53$ & $38-52$ & $40-50$ \\
\hline
\end{tabular}

Onde:

$+=90 \%$ das cepas são positivas;

- =90\% das cepas são negativas;

$\mathrm{V}=$ variável; e

$\mathrm{ND}=$ não determinado.

Existem aproximadamente vinte e sete espécies de Rhodococcus separadas pela diversidade do metabolismo, aplicação industrial ou potencial de biorremediação (GYLES, et al. 2004), dentre elas encontra-se a espécie opacus que será melhor discutida devido sua importância nesse trabalho.

\subsubsection{Rhodococcus opacus}


A $R$. opacus é uma bactéria não patogênica, gram-positiva, aeróbia e unicelular (STRATTON et al., 2002) apresenta hidrofobicidade (FINNERTY, 1992) e propriedades anfóteras (MESQUITA, 2007 apud BUENO, 2007) que pode ser isolada de solos e das usinas de tratamento de águas (STRATTON et al., 2002).

O comportamento anfótero da superfície celular é decorrente das propriedades dos diferentes tipos de compostos presentes na parede do microrganismo, sendo que os principais componentes são polissacarídeos, ácidos carboxílicos, ácidos micólicos e lipídeos. Esta característica torna esta espécie microbiana um potencial agente de sorção (MESQUITA et al., 2003).

A composição da parede celular da Rhodococcus opacus foi estudada por Botero, Torem e Mesquita (2008), os resultados obtidos estão apresentados na Tabela 7 onde é possível verificar a alta proporção de carboidratos e lipídios.

Tabela 7 - Composição da parede celular da Rhodococcus opacus. (adaptado de BOTERO, TOREM \& MESQUITA, 2008)

\begin{tabular}{lcc}
\hline $\begin{array}{l}\text { Componente da } \\
\text { parede celular }\end{array}$ & $\begin{array}{c}\text { Concentração } \\
\left(\mathbf{g . d m}^{-3} \mathbf{)}\right.\end{array}$ & $\begin{array}{c}\text { Composição } \\
(\%)\end{array}$ \\
\hline Proteinas & 0,16 & 2,85 \\
Carboidratos & 0,61 & 10,54 \\
Lipidios & 1,92 & 33,33 \\
Suspensão celular & 11,52 & \\
\hline
\end{tabular}

Além das características supracitadas, a facilidade de manipulação, propagação e manutenção das células e a disponibilidade em coleção de culturas nacionais foram fatores determinantes para a escolha deste microrganismo (BUENO, 2007).

Muitos processos industriais e de tratamento ambiental utilizam o $R$. opacus na bioremediação de hidrocarbonetos, herbicidas e outros componentes xenobióticos assim como no tratamento de solos contaminados com óleos (ALVAREZ et al., 2004; FINNERTY, 1992; GOODFELLOW, 1998).

\subsection{Adsorção}


Dentre os mecanismos anteriormente mencionados, o mais comum para a explicação do fenômeno de biossorção é a adsorção.

A adsorção é um processo no qual a captação do metal ocorre através de interações entre o cátion metálico e a superfície do biossorvente (GARCIA JR., 1997). No processo de adsorção, o material sólido é designado de adsorvente e a solução contendo os íons metálicos de adsorvato.

A retenção dos íons metálicos na superfície pode ocorrer devido às forças de atração existentes na superfície do sólido originadas por uma falta de compensação de atrações, ou ligações dos átomos superficiais. Se considerarmos um átomo ou íon no centro de um sólido cristalino, é razoável supor que está sendo submetido a forças de atrações simétricas ao redor de seu campo. Se o átomo está na superfície, ele está exposto a forças de atração dos átomos do interior do sólido cristalino, mas como ocorre falta de compensação simétrica nesses átomos superficiais, é gerada uma atração nos compostos (ou partículas) que passam pela superfície do sólido (BUENO, 2007).

A adsorção pode ser classificada como adsorção química e física, dependendo da natureza das forças superficiais, sendo que, em certos casos, os dois tipos podem ocorrer simultaneamente (VOLESKY, 2003). O mecanismo de ligação entre o metal e a superfície celular pode ser físico, ligação eletrostática e força de Van der Waals, ou químico, ligação iônica e covalente (DAVIS, VOLESKY \& MUCCI, 2003). As diferenças entre adsorção física e quimissorção podem ser visualizadas na Tabela 8 (BUENO, 2007).

Tabela 8 - Diferenças entre adsorção física e adsorção química (Adaptado de BUENO, 2007). 


\begin{tabular}{c|l|l}
\hline $\begin{array}{c}\text { Forças de } \\
\text { ligação }\end{array}$ & Van der Waals & Ligações químicas \\
\hline $\begin{array}{c}\text { Calor de } \\
\text { adsorção }\end{array}$ & Inferior a 20KJ/mol & Superior a 20KJ/mol \\
\hline $\begin{array}{c}\text { Espécie } \\
\text { adsorvida }\end{array}$ & $\begin{array}{l}\text { Conserva sua } \\
\text { natureza }\end{array}$ & $\begin{array}{l}\text { Sofre transformação } \\
\text { gerando uma nova } \\
\text { espécie }\end{array}$ \\
\hline $\begin{array}{c}\text { Quantidade } \\
\text { adsorvida }\end{array}$ & $\begin{array}{l}\text { Depende mais do } \\
\text { adsorvato do que do } \\
\text { adsorvente }\end{array}$ & $\begin{array}{l}\text { Depende tanto do } \\
\text { adsorvato quanto do } \\
\text { adsorvente }\end{array}$ \\
\hline $\begin{array}{c}\text { Especificidade } \\
\text { Temperatura de } \\
\text { adsorção }\end{array}$ & $\begin{array}{l}\text { Baixa } \\
\text { abaixo do ponto de } \\
\text { ebulição do adsorvato }\end{array}$ & $\begin{array}{l}\text { Pode ocorrer também a } \\
\text { temperaturas elevadas }\end{array}$ \\
\hline $\begin{array}{c}\text { Energia de } \\
\text { ativação }\end{array}$ & Baixa & Alta \\
\hline $\begin{array}{c}\text { Camadas de } \\
\text { Adsorção }\end{array}$ & $\begin{array}{l}\text { É possível adsorção } \\
\text { em multicamadas }\end{array}$ & $\begin{array}{l}\text { Adsorção no máximo } \\
\text { em monocamadas }\end{array}$ \\
\hline Dessorção & Fácil & $\begin{array}{l}\text { Difícil ou acompanhada } \\
\text { de transformações } \\
\text { químicas }\end{array}$ \\
\hline
\end{tabular}

A troca iônica é um mecanismo de ligação importante capaz de explicar muitas das observações feitas durante experimentos de adsorção de metais pesados (DAVIS, VOLESKY \& MUCCI, 2003). Resultados obtidos em pesquisas de biossorção evidenciam que este é o principal mecanismo de biossorção (KRATOCHVIL \& VOLESKY, 1998).

Volesky (1990) explica que em todas as dimensões de um sólido polimérico ocorre troca iônica, onde compostos com cargas positivas ou negativas na fase líquida deslocam íons não semelhantes, porém com o mesmo tipo de carga do biossorvente. Na parede celular dos microrganismos encontram-se polissacarídeos que são basicamente blocos que contêm os ânions e cátions responsáveis pela troca iônica (VEGLIO \& BEOLCHINI, 1997).

O mecanismo de troca iônica está baseado na troca de íons com diferentes afinidades pelo biossorvente e, dependendo das condições do meio, o íon com maior afinidade é capaz de trocar de posição com o íon do sítio ativo, realizando-se assim a troca de iônica (Equação 4) (VÁSQUEZ, 2005). 


$$
H_{N} B+M e^{n+}=M e B+n H^{+}
$$

Onde:

$\mathrm{Me}=$ metal;

$\mathrm{N}=$ carga do metal;

$\mathrm{B}=$ sítios ativos da biomassa.

\subsubsection{Isotermas}

O método mais apropriado para avaliar a capacidade de captação de biossorvente é através da construção e análise de isotermas. A isoterma de sorção é o equilíbrio entre a concentração na fase líquida e a concentração nas partículas de adsorventes numa dada temperatura (WANG \& QUIN, 2005).

Os principais objetivos das isotermas são a compreensão dos mecanismos de ligação, a afinidade da biomassa com os metais e como ambos são afetados por variações das condições ambientais (DAVIS, VOLESKY \& MUCCI, 2003). As isotermas também podem ser usadas para comparar diferentes biossorventes e a afinidade de diferentes substâncias pelo mesmo biossorvente.

O primeiro passo para atingir esses objetivos é quantificar a capacidade da biomassa em seqüestrar os metais da solução aquosa. A reação é monitorada pela medida periódica da quantidade de metal remanescente na solução até que esta concentração não varie mais com o tempo (DAVIS, VOLESKY \& MUCCI, 2003).

A determinação da taxa de remoção de um metal pelo biossorvente é freqüentemente baseada no estado de equilíbrio do sistema de sorção. A taxa de sorção é usualmente expressa em miligramas do metal sorvido por gramas de sorvente seco (KRATOCHVIL \& VOLESKY, 1998)

Os dados para construção de isotermas de sorção são obtidos experimentalmente conforme esquema apresentado na Figura 19 (VOLESKY, 2007). 


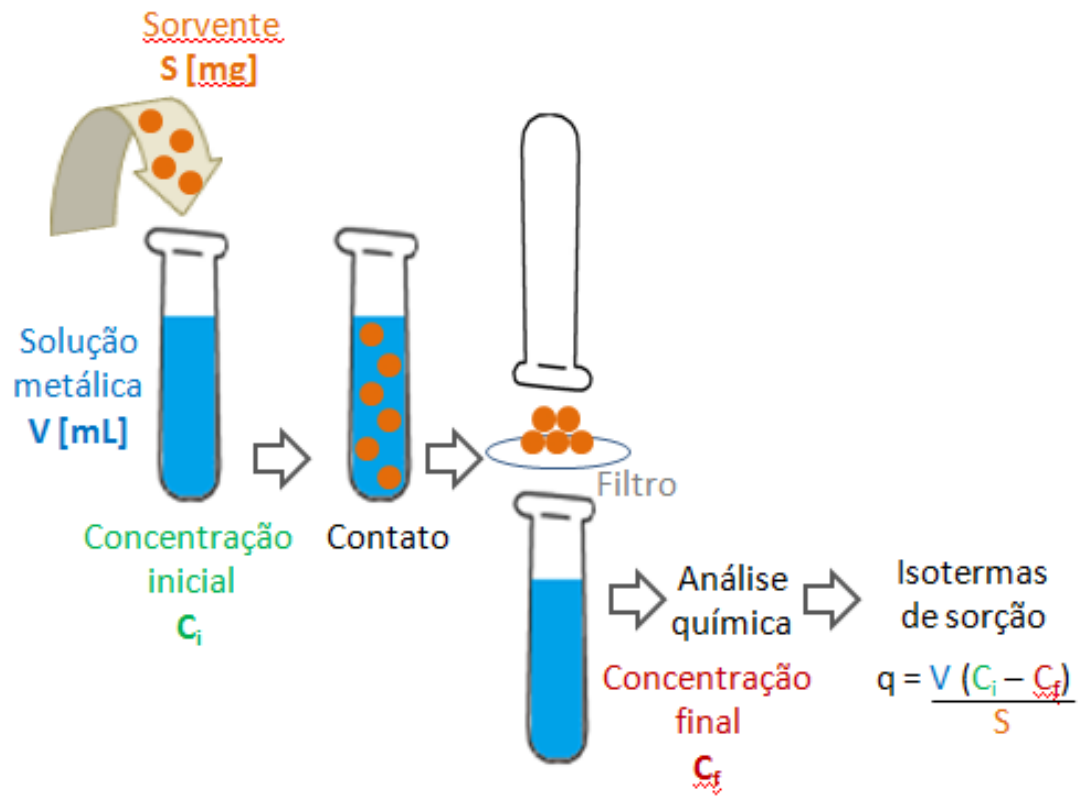

Figura 19 - Esquema do procedimento experimental para obtenção de dados para a construção de isotermas de sorção

(adaptado de VOLESKY, 2007).

As isotermas construídas a partir de dados coletados com a utilização de solutos orgânicos foram classificadas por Oscik (1982) apud Bueno (2007) em quatro classes segundo a natureza inicial da curva que descreve a isoterma e as variações de cada classe. Além disso, as isotermas também foram divididas em subgrupos de acordo com a configuração final dessas curvas (Figura 20).

As quatro principais classes de isotermas são: $S, L, H$ e C. Sendo que $S$ e L são isotermas do tipo Langmuir, $\mathrm{H}$ isoterma de alta afinidade e $\mathrm{C}$ isoterma constante de partição (Figura 20). 


\section{CLASSES}

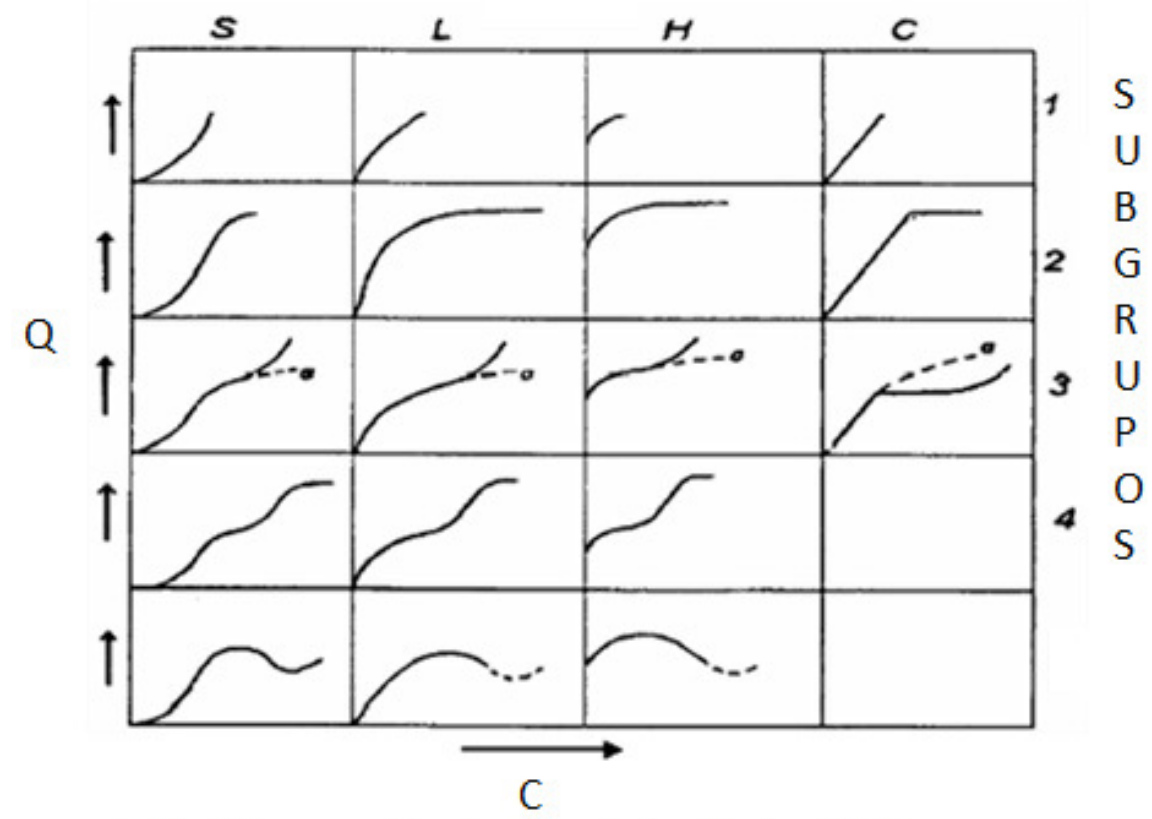

Onde: $\mathrm{Q}$ é concentração de metal captado pela biomassa; e C é a concentração do soluto em equilíbrio

Figura 20 - Sistema para classificação de isotermas (OSCIK, 1982 apud BUENO, 2007).

As isotermas do tipo $S$ só aparecem quando as três condições seguintes são satisfeitas: a molécula do soluto é mono funcional (razoavelmente hidrofóbicas); existe interação moderada causando empacotamento vertical das moléculas na superfície do sólido; e há competição das moléculas do soluto ou de outras moléculas adsorvidas pelos sítios do sorvente (BUENO, 2007).

Para ocorrerem isotermas do tipo $L$ é necessário que as moléculas sejam adsorvidas em camadas, isto é, a adsorção ocorre horizontalmente; e deve haver uma pequena competição pelos sítios da superfície do biossorvente pelos íons presentes na solução. Nestas situações, a dificuldade de se preencher os sítios vagos por outras moléculas de soluto cresce com a quantidade de sítios já preenchidos. Segundo BUENO (2007), foi verificado que curvas classe $L$ subgrupo 2 ocorrem majoritariamente quando se trabalha com soluções diluídas. Já as isotermas do tipo $\mathrm{H}$ representam um caso especial de $\mathrm{L}$ e neste caso o soluto apresenta alta afinidade e é completamente adsorvido pelo sólido.

As condições que favorecem o aparecimento de curvas tipo $C$ são: presença de moléculas "flexíveis" nos poros do suporte, tendo regiões com diferentes graus de 
cristalinidade; e o soluto deve apresentar maior afinidade pelo adsorvente que o solvente. Por esses motivos, isotermas representadas por curvas do tipo C caracterizam uma partição entre o soluto e o adsorvente. Este tipo de curva é obtido para partição de um soluto em dois solventes imiscíveis (BUENO, 2007).

Na Figura 21 (VOLESKY, 2007), podemos visualizar um exemplo comparativo de isotermas de sorção.

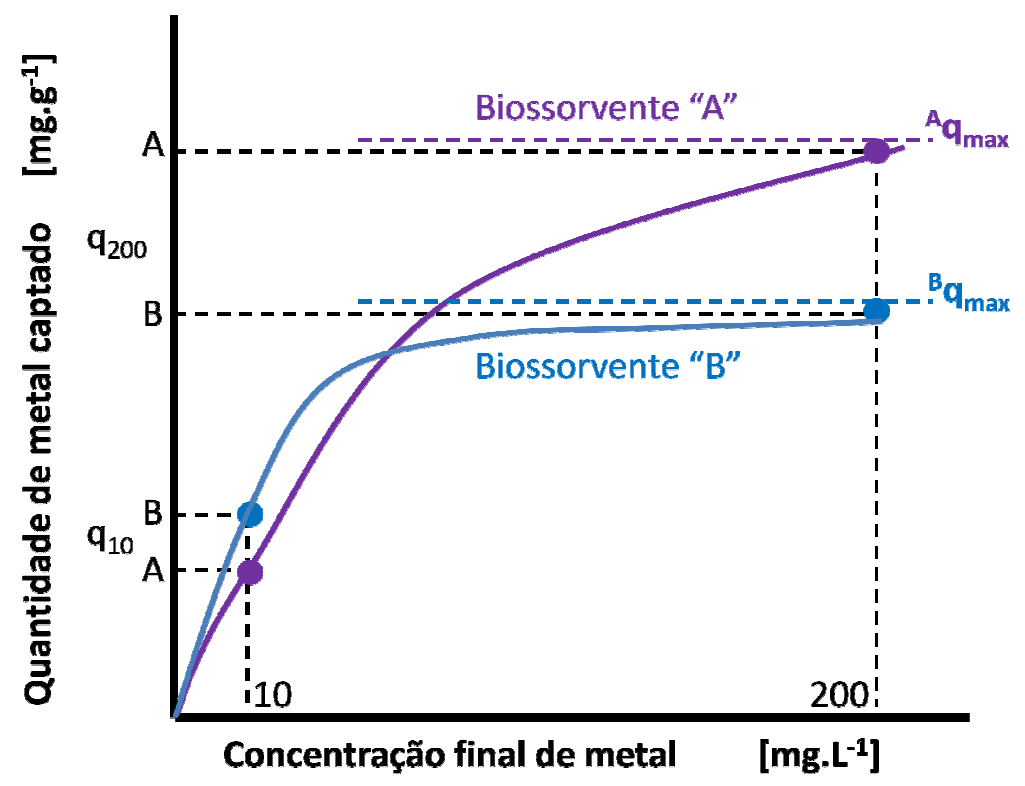

Figura 21 - Exemplos comparativos de isotermas de sorção (adaptado de VOLESKY, 2007).

Modelos de isoterma de equilíbrio são geralmente classificados em equações empíricas e modelos mecanicistas, com base no mecanismo de biossorção de íons metálicos. Modelos mecanicistas podem ser usados não apenas para representar, mas também para explicar e predizer o comportamento experimental (LIU \& LIU, 2002; PAGNANELLI et al., 2002)

As equações de Langmuir e Freundlich são os modelos de isotermas mais freqüentemente utilizados. Na literatura eles descrevem o equilíbrio não-linear entre o poluente adsorvido nas células e os poluentes em solução a uma temperatura constante. Estes modelos são simples e capazes de fornecer uma boa descrição do comportamento experimental em uma ampla gama de condições de funcionamento, porém são caracterizados por um número limitado de parâmetros passiveis de ajuste (AKSU \& DÖNMEZ, 2006). 
Ambos os modelos foram desenvolvidos para a adsorção de uma única camada de metal. No entanto, o modelo de Freundlich fornece fisicamente uma descrição mais realista da adsorção. Mas, na maioria dos casos, ambas as equações de ajuste do conjunto de dados descrevem bem os dados experimentais. (AKSU \& DÖNMEZ, 2006).

Uma das dificuldades em descrever o equilíbrio de adsorção de íons metálicos de águas residuais é a presença de muitos íons metálicos dissolvidos. Quando vários componentes estão presentes, fenômenos de interferência e competição pelos sítios de adsorção ocorrerem e levam a uma matemática mais complexa para a formulação do equilíbrio (AKSU \& DÖNMEZ, 2006).

Para descrever sistemas de biossorção com dois ou vários íons metálicos, os modelos amplamente utilizados e aceitos são: de Langmuir (tipo L, com base na adsorção de monocamada de soluto) e de Freundlich (tipo F, desenvolvido para superfícies heterogêneas). No entanto, esses modelos empíricos dificilmente podem explicar o comportamento da biossorção levando em consideração interpretações físicas, e conclusões sobre as previsões não podem ser elaboradas para os sistemas operacionais com condições diferentes. As conclusões considerando apenas o bom ajuste dos modelos mecanicistas devem ser evitadas. Além disso, isotermas de biossorção podem apresentar um padrão irregular, devido à natureza complexa de ambos os elementos envolvidos: os biomateriais e sua variedade de sítios ativos, e a química complexa da solução dos compostos metálicos (VOLESKY \& HOLAN, 1995; KAPOOR \& VIRARAGHAVAN, 1995). 


\section{OBJETIVOS}

O desenvolvimento deste trabalho tem por objetivo estudar os seguintes aspectos relacionados ao tratamento de DAM por biossorção:

- Caracterizar a biomassa Rhodococcus opacus através de análises físico-quimicas: perda ao fogo, microscopia eletrônica de varredura/EDS, infravermelho e potencial zeta.

- Avaliar a habilidade e eficiência da bactéria Rhodococcus opacus como biossorvente para o tratamento de drenagem ácida de minas em uma amostra sintética.

- Determinar o tempo de equilíbrio no processo de biossorção em batelada utilizando Rhodococcus opacus e mantendo constante agitação, temperatura e $\mathrm{pH}$.

- Estudar a cinética do processo de sorção dos metais presentes na DAM por Rhodococcus opacus.

- Estudar as mudanças na estrutura do microrganismo após a sorção dos íons metálicos através de análises de microscopia eletrônica de varredura/EDS, infravermelho e potencial zeta. 


\section{MATERIAIS E MÉTODOS}

\subsection{Coleta e caracterização das DAMs reais}

\subsubsection{Coleta}

Coletaram-se amostras de DAM de dois locais no estado de Santa Catarina: de uma bacia de adução em uma carbonífera localizada em Forquilhinha (Figuras 22 e 23) e de uma boca de mina abandonada localizada em Criciúma (Figura 24), identificadas neste trabalho como EDR3 e SS16, respectivamente.

A coleta de ambas as amostras foi feita utilizando-se bombonas plásticas de 30 e 50L previamente ambientadas com a DAM em questão e datam da primeira semana de dezembro de 2009.

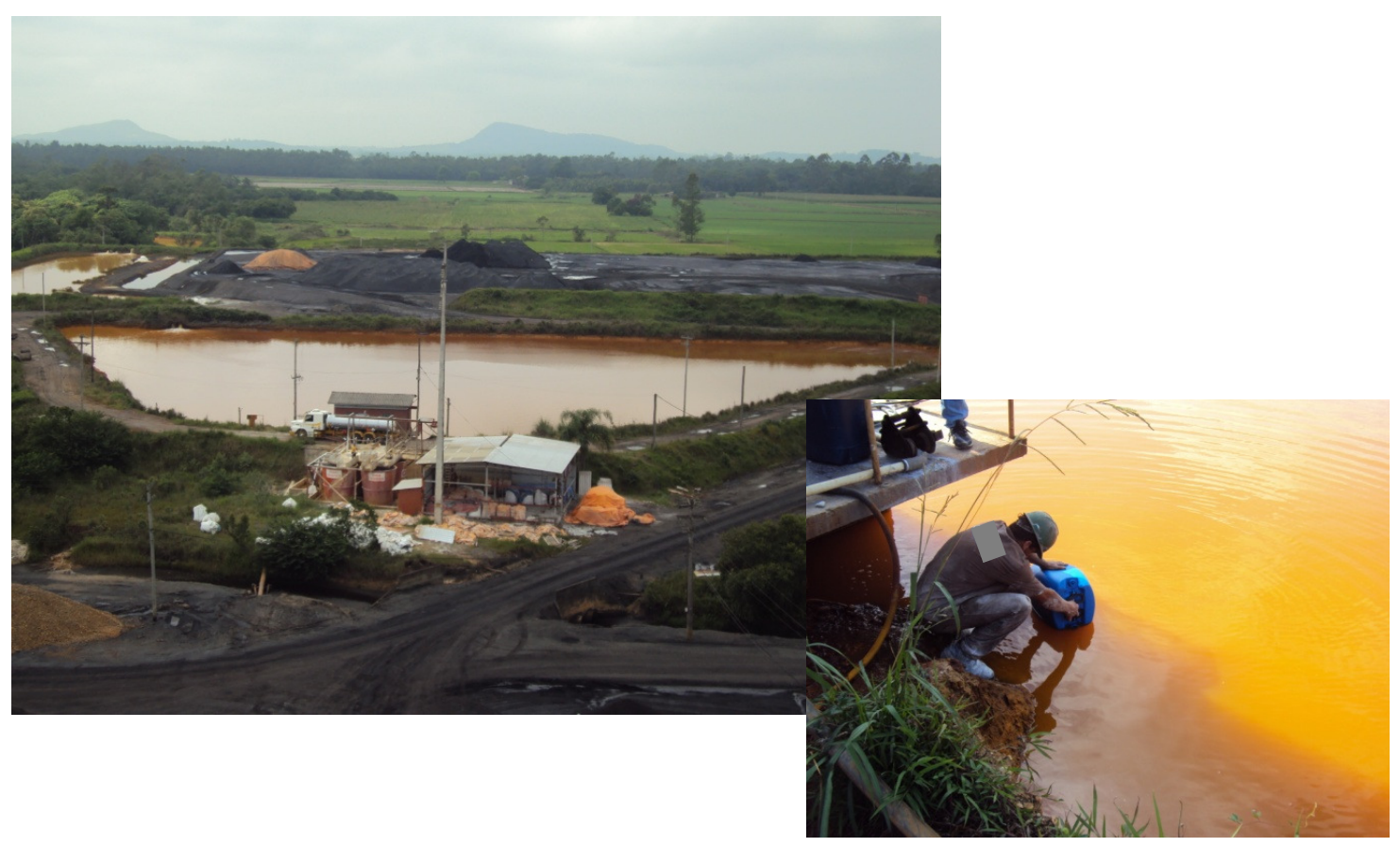

Figura 22 - Bacia de adução EDR3, Forquilhinha - SC. 


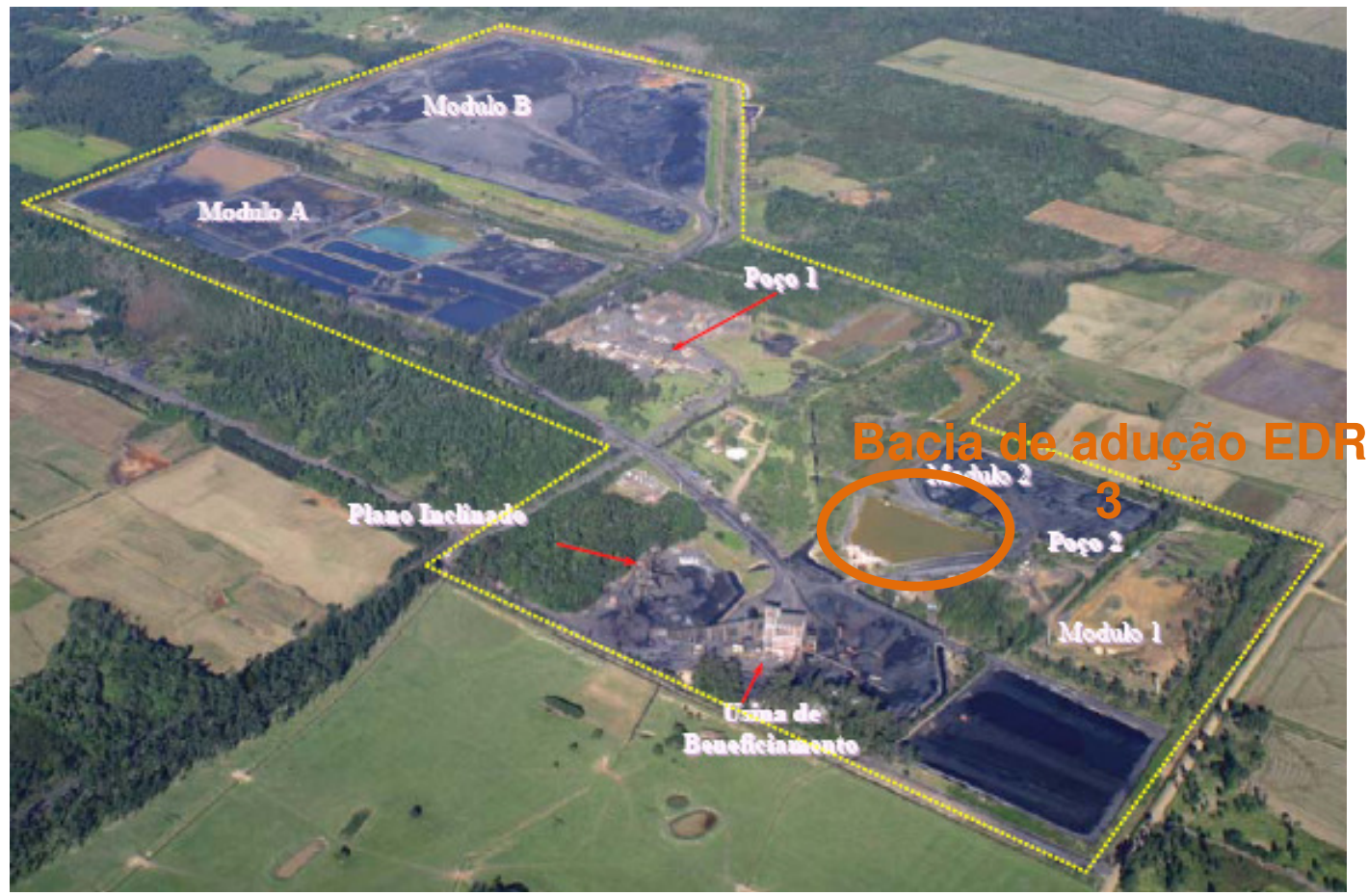

Figura 23 - Vista superior da carbonífera, em destaque a bacia de adução de onde foi retirada a amostra EDR3

(Adaptado de SCHNEIDER, 2006).

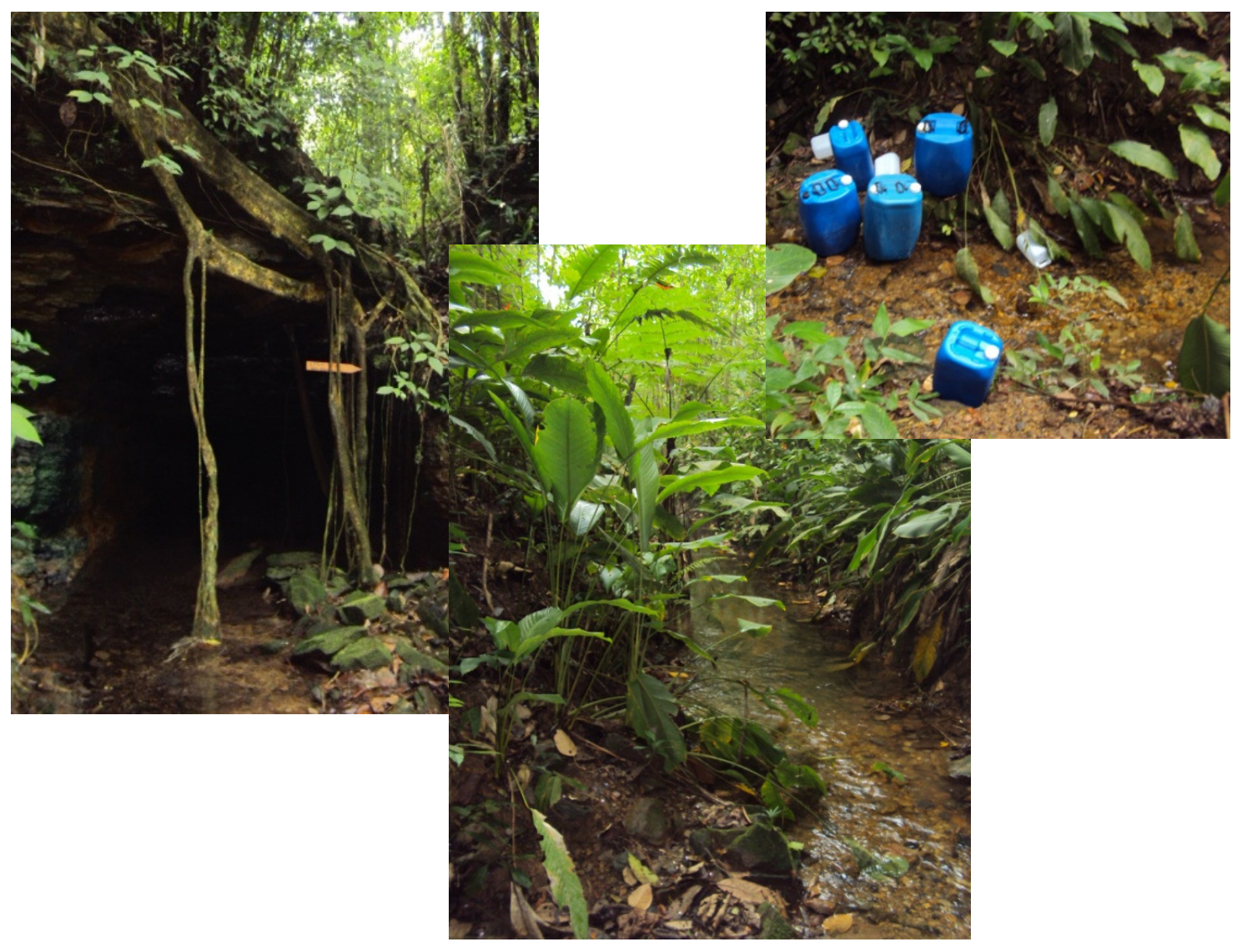


Figura 24 - Boca de mina abandonada, Criciúma - SC

Fez-se a escolha dos locais de coleta de modo a conseguir amostras com características diferentes capazes de representar duas situações distintas por serem provenientes de diferentes fontes:

1ㄹ - A DAM coletada na bacia de adução possui alta concentração de metais dissolvidos, pois recebe os efluentes gerados em toda a unidade carbonífera (Figura 25). Esse efluente "pode ser comparado" com drenagens encontradas em lagoas ácidas ao redor de pilhas de rejeitos abandonadas. Segundo Gomes (2004), há 77 lagoas ácidas e 115 áreas com depósitos de rejeitos no sul de Santa Catarina.

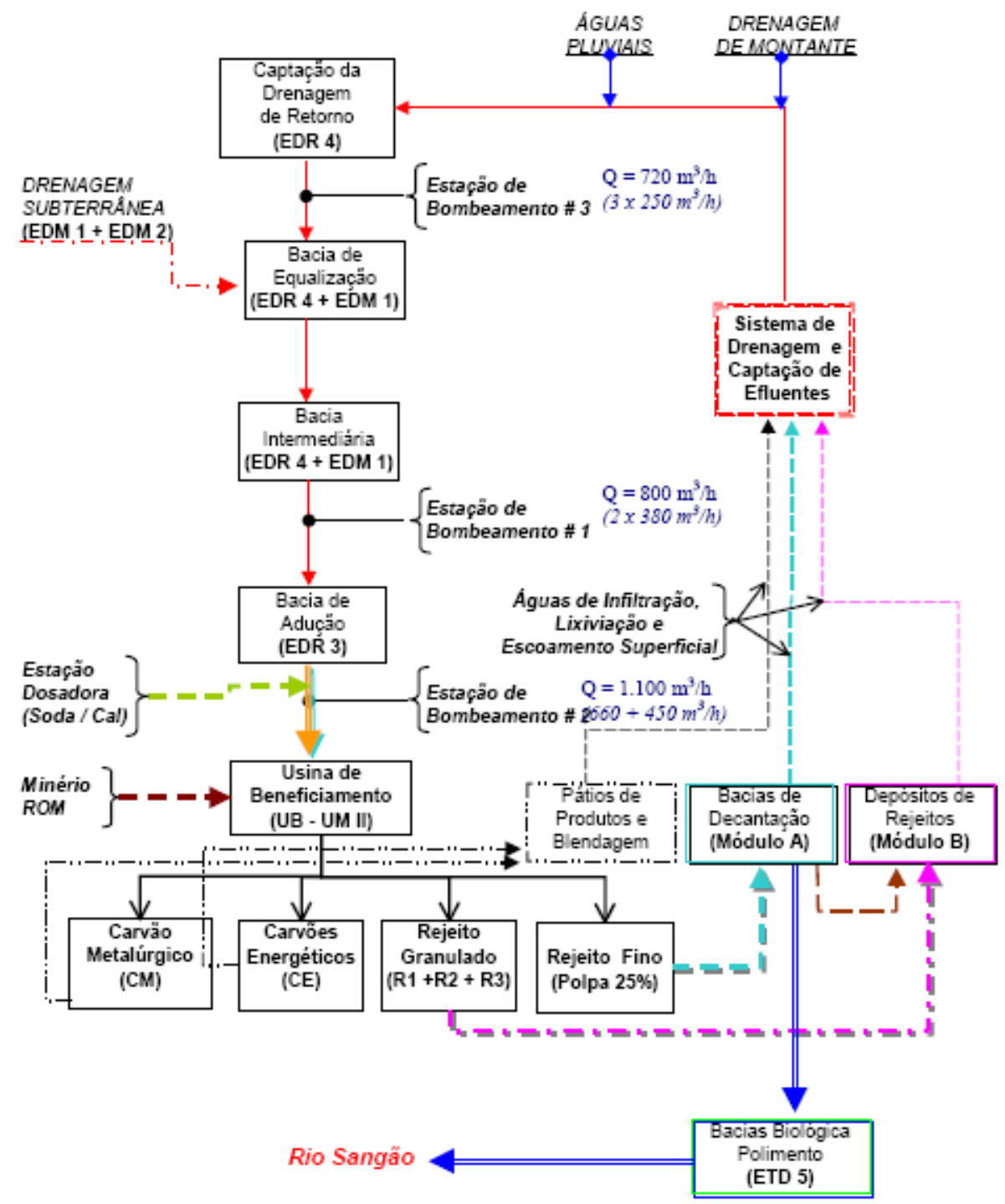

Figura 25 - Fluxograma do sistema de drenagem da carbonífera onde foi coletada a amostra EDR3

(SCHNEIDER, 2006). 
$2^{\mathrm{a}}$ - A amostra SS16 proveniente de uma boca de mina abandonada, "representa" DAMs geradas na mesma situação e, assim como esta, estima-se a ocorrência de aproximadamente 1.000 bocas de minas abandonadas e até novembro de 2008 foram cadastradas aproximadamente 768 bocas de minas nesta situação, na região (AMARAL et al, 2009).

Vale ressaltar que a composição de cada DAM varia e depende de muitos fatores e, portanto, não se pode afirmar que as amostras estudadas são representativas para todas as situações mesmo quando provenientes de fontes similares.

Após coleta, alíquotas de 100mL foram acidificadas com ácido nítrico a fim de preservar as amostras para posterior caracterização.

\subsubsection{Caracterização}

A concentração de: Al, Cd, Cr, Cu, Fe, Mg, Mn, Ni, Pb e Zn foi determinada através de espectrometria de absorção atômica em Espectrofotômetro de absorção atômica modelo AA240 da marca Varian Inc.

A determinação dos teores de $\mathrm{Ca}, \mathrm{K}$, sulfato e cloreto se deram através de cromatografia iônica (modelo ICS2000 da marca Dionex Brasil Instrumentos Científicos Ltda). Para a análise no cromatógrafo as amostras foram previamente filtradas em membrana de 0,45 $\mu \mathrm{m}$.

\subsection{Preparação da DAM sintética}

Os ensaios de biossorção foram realizados utilizando uma DAM sintética adaptada da estudada por Wei et al, (2005) cujos dados encontram-se na Tabela 9. A partir de agora, essa amostra será referenciada apenas como DAM WEI. 
Tabela 9 - Características da drenagem ácida de minas (adaptado de WEl et al., 2005).

Concentração (mg. $\left.\mathrm{L}^{-1}\right)$

\begin{tabular}{llllllllll}
\hline $\mathbf{p H}$ & $\mathrm{Fe}$ & $\mathrm{Al}$ & $\mathrm{Ca}$ & $\mathrm{Mg}$ & $\mathrm{Mn}$ & $\mathrm{Zn}$ & $\mathrm{Ni}$ & $\mathrm{Cu}$ & $\mathrm{SO}_{4}$ \\
\hline $\mathbf{2 , 6}$ & \multirow{2}{*}{162} & 80,8 & \multirow{2}{*}{191} & 50,5 & 2,03 & 2,72 & 1,01 & 0,08 & 1527 \\
\hline
\end{tabular}

A solução foi preparada utilizando-se sulfatos $\left(\mathrm{MgSO}_{4} \cdot \mathrm{H}_{2} \mathrm{O}, \mathrm{MnSO}_{4} \cdot \mathrm{H}_{2} \mathrm{O}\right.$, $\mathrm{ZnSO}_{4} .7 \mathrm{H}_{2} \mathrm{O}, \mathrm{NiSO}_{4} \cdot 6 \mathrm{H}_{2} \mathrm{O}, \mathrm{CuSO}_{4} .5 \mathrm{H}_{2} \mathrm{O}$ e $\left.\mathrm{FeSO}_{4} .7 \mathrm{H}_{2} \mathrm{O}\right)$, nitratos $\left(\mathrm{Ca}\left(\mathrm{NO}_{3}\right)_{2}\right.$ e $\left.\mathrm{Al}\left(\mathrm{NO}_{3}\right)_{3} \cdot 9 \mathrm{H}_{2} \mathrm{O}\right)$ e cloreto $(\mathrm{NaCl})$ diluídos em água deionizada, e corrigiu-se $\circ \mathrm{pH}$ utilizando ácido sulfúrico $\left(\mathrm{H}_{2} \mathrm{SO}_{4} 1 \mathrm{~N}\right)$.

Após preparada, uma alíquota de $50 \mathrm{~mL}$ foi acidificada com ácido nítrico, de modo a preservar a amostra, e caracterizada por espectrofotometria de absorção atômica a fim de se obter as concentrações objetivadas de cada elemento.

\subsection{Procedência e preparo da biomassa}

Fez-se a aquisição da cepa do microrganismo Rhodococcus opacus junto ao Centro Pluridisciplinar de Pesquisas Químicas, Biológicas e Agrícolas - CPQBA (Unicamp).

\subsubsection{Repicagem}

Repicou-se a bactéria no laboratório a fim de se manter um estoque de microrganimos e o procedimento seguiu conforme a Figura 26.

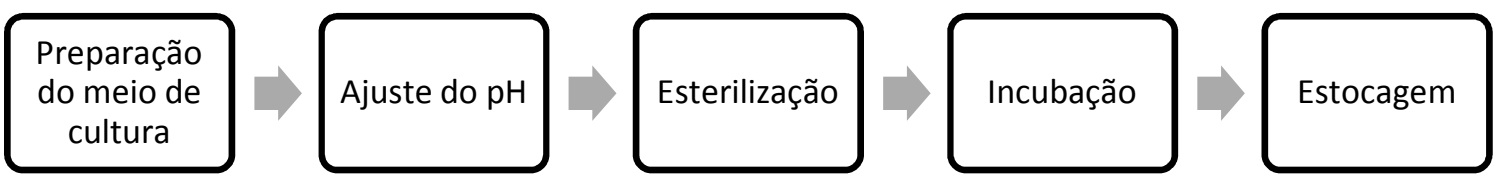

Figura 26 - Fluxograma das etapas do processo de repicagem 
Preparou-se o meio de cultura YMA conforme composição descrita na Tabela 10 e ajustou-se o pH para 7,2 (com auxílio de um pHmetro da marca MS Tecnopon Equipamentos Especiais Ltda, modelo mPA-210) com NaOH (BUENO, 2007).

\begin{tabular}{l|c}
\multicolumn{2}{l}{ Tabela 10 - Composição do meio de cultura YMA } \\
\hline \multicolumn{1}{c}{ Reagente } & Concentração $\left(g \cdot \mathrm{L}^{-1}\right)$ \\
\hline Agar & 20 \\
\hline Glicose & 10 \\
\hline Peptona & 5 \\
\hline Extrato de malte & 3 \\
\hline Extrato de levedura & 3 \\
\hline Carbonato de cálcio & 2 \\
\hline
\end{tabular}

O meio de cultura foi colocado em erlenmeyer, tampado com algodão hidrófobo e papel Kraft para então ser autoclavado a $121^{\circ} \mathrm{C}$, $1 \mathrm{~atm}$ por $20 \mathrm{~min}$.

Após esterilização, distribuiu-se o meio em placas de petri e tubos de ensaio previamente autoclavados e após endurecimento fez-se a inoculação. A incubação ocorreu a $28^{\circ} \mathrm{C}$ por $48 \mathrm{~h}$ e após este período de crescimento, manteve-se o material sob refrigeração $\left(\approx 5^{\circ} \mathrm{C}\right)$.

\subsubsection{Preparo da biomassa}

Preparou-se o caldo de crescimento dos microrganismos seguindo a mesma composição do meio de cultura (Tabela 10), porém não se adicionou agar e carbonato de sódio.

Fez-se a inoculação das bactérias utilizando-se os repiques obtidos anteriormente e o crescimento foi realizado nos mesmos frascos com capacidade para $1 \mathrm{~L}$, por um período de $24 \mathrm{~h}$, a temperatura ambiente e sob agitação de $150 \mathrm{rpm}$ em shaker modelo TE-140 da Tecnal.

Após o crescimento separou-se a cultura por centrifugação (centrífuga excelsa II, Fanem. Modelo 206BL) a uma velocidade de 2000rpm por 12min (Figura 27). Lavou-se o precipitado obtido com água deionizada e uma nova centrifugação foi feita utilizando o mesmo tempo e velocidade. Então, o precipitado obtido foi 
suspenso em solução de $\mathrm{NaCl}$ 0,1mM (MESQUITA, 2000 apud BUENO, 2007) sendo posteriormente esterilizado em autoclave a 1atm de pressão durante $20 \mathrm{~min}$ (Figura 28).

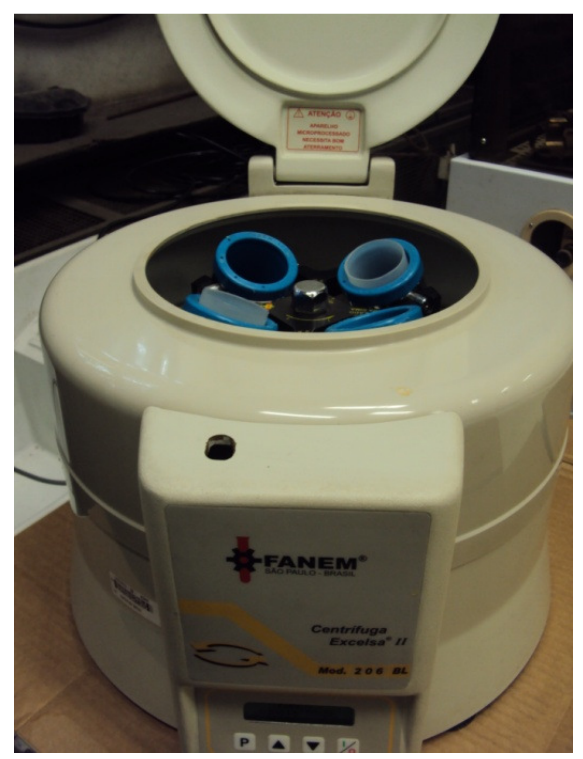

Figura 27 - Centrífuga excelsa II Fanem. Modelo 206BL

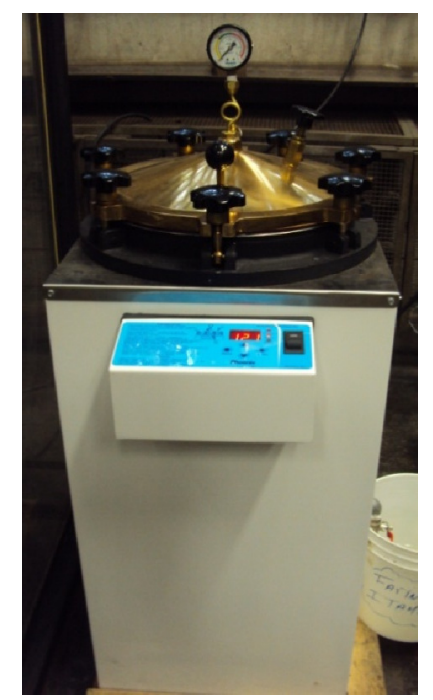

Figura 28 - Autoclave vertical Phoenix, modelo Av Plus

Realizou-se então a determinação da concentração celular pelo método de peso seco: mediu-se em proveta um volume conhecido $(2 \mathrm{~mL})$ que foi então colocado em cadinho previamente tarado e mantido em estufa Fanem, Modelo 515A Orion, a $60^{\circ} \mathrm{C}$ por $36 \mathrm{~h}$. Após secagem, a amostra foi pesada. O processo foi feito em triplicata e considerou-se como a concentração celular da solução a média dos ensaios.

A solução foi estocada sob refrigeração para posterior utilização nos ensaios biossortivos.

$\mathrm{Na}$ Figura 29, encontram-se de modo simplificado todas as etapas para preparação da biomassa que será utilizada nos ensaios de biossorção. 


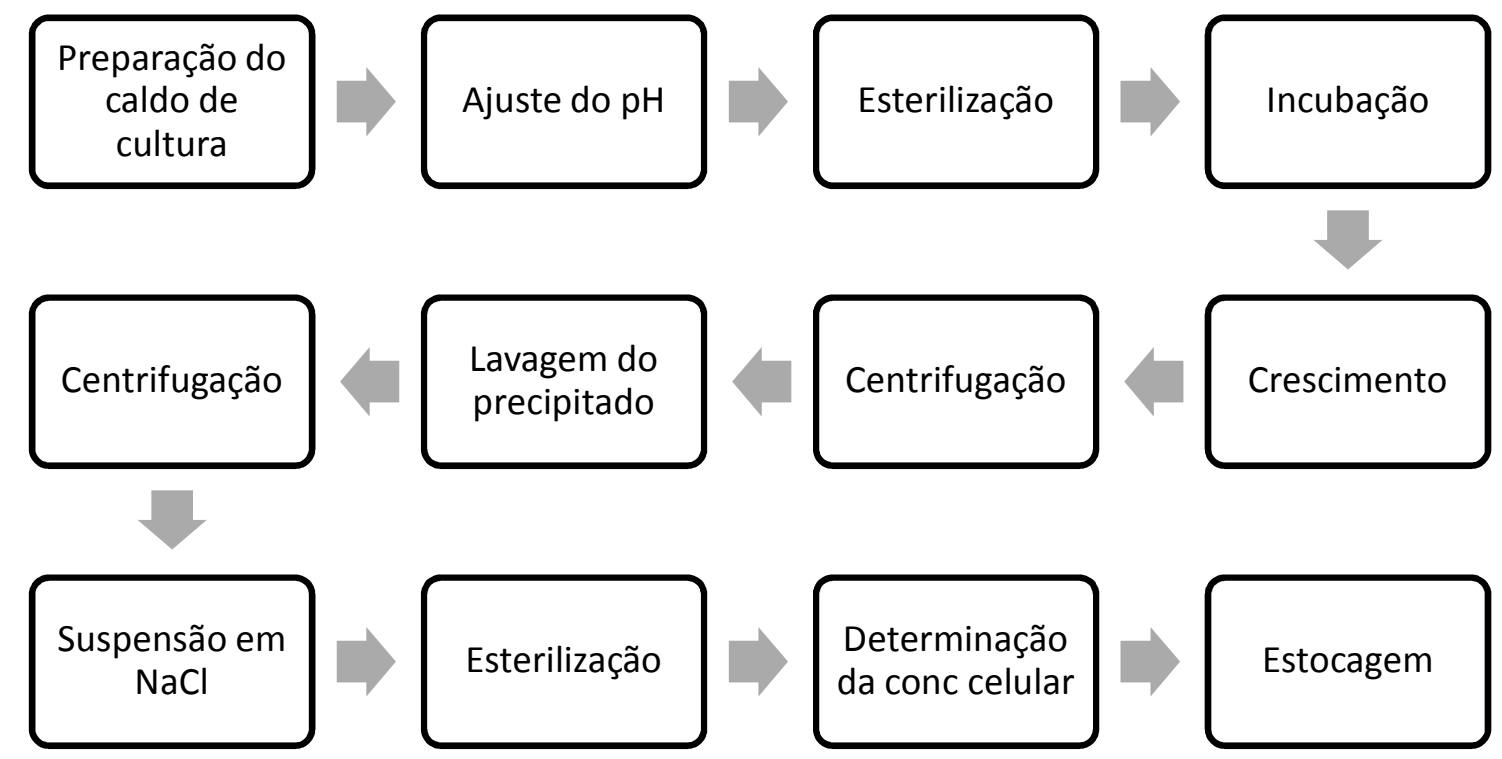

Figura 29 - Fluxograma das etapas do processo de preparação da biomassa

\subsection{Experimentos de biossorção}

Os ensaios biossortivos foram realizados em batelada, em escala laboratorial e utilizando-se primeiramente a DAM sintética WEI. Dentre os fatores que afetam a taxa de adsorção ( $\mathrm{pH}$, concentração de biossorvente e tempo de contato), o tempo de contato foi o único parâmetro estudado até o momento. O tempo de contato foi analisado em ensaios realizados a temperatura ambiente, com a suspensão celular, em frascos erlenmeyer de 250ml sob agitação constante de 175 rpm numa incubadora orbital da marca Tecnal, modelo TE-420. Os demais parâmetros também serão estudados nas mesmas condições de trabalho. Na Figura 30 encontra-se o esquema de trabalho. 


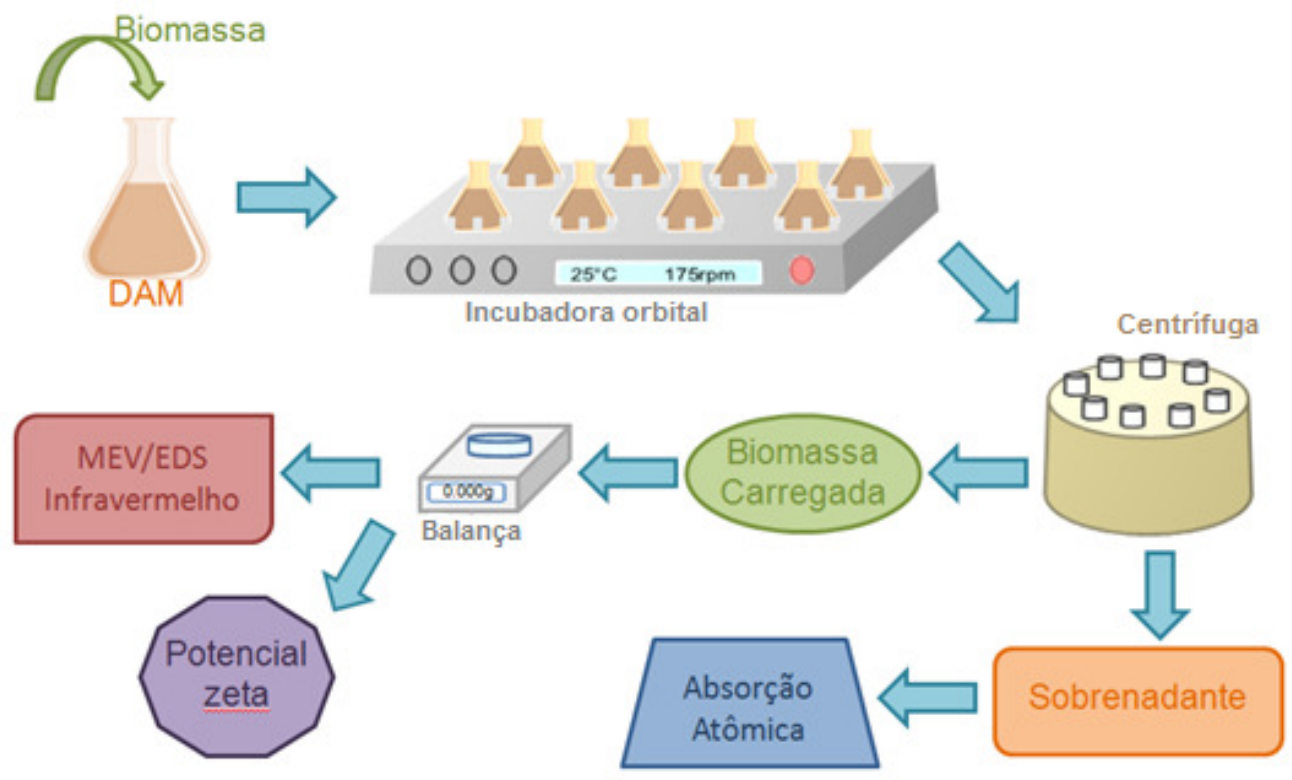

Figura 30 - Esquema dos ensaios.

Optou-se por realizar os ensaios à temperatura ambiente, uma vez que estudos realizados até o momento têm demonstrado que na faixa de 5 a $35^{\circ} \mathrm{C}$ a temperatura exerce pouco efeito sobre a biossorção (AKSU \& KUTSAL, 1991; TSEZOS \& VOLESKY, 1981). Segundo Hayashi (2001), pode-se trabalhar a temperatura ambiente, não havendo a necessidade de fornecer energia para aumentar a remoção, reforçando a vantagem de ser um processo de baixo custo.

\subsubsection{Determinação do tempo de equilíbrio}

Estudou-se o tempo de contato entre a biomassa e as soluções contendo íons metálicos para determinar qual o tempo necessário para a máxima captação de metais pela Rhodococcus opacus.

$\mathrm{Na}$ Tabela 11 podem-se verificar os diferentes tempos de contato que foram estudados a fim de se determinar quando o equilíbrio é atingido, na mesma tabela encontram-se as demais condições experimentais empregadas. 
Tabela 11 - Condições empregadas para determinação do tempo de equilíbrio

\begin{tabular}{ll}
\hline \multicolumn{1}{c}{ Parâmetro } & \multicolumn{1}{c}{ Valores } \\
\hline Volume da solução (DAM WEl) & $50 \mathrm{~mL}$ \\
\hline Concentração da biomassa & $1 \mathrm{~g} \cdot \mathrm{L}^{-1}$ \\
\hline Velocidade de agitação & $175 \mathrm{rpm}$ \\
\hline Temperatura & $25 \pm 2{ }^{\circ} \mathrm{C}$ \\
\hline $\mathrm{pH}$ & $\begin{array}{l}2,6 \text { (inicial = DAM } \\
\text { bruta) }\end{array}$ \\
\hline Tempo & $\begin{array}{l}1,3,5, \quad \mathrm{e} \\
\text { minutos }\end{array}$ \\
\hline
\end{tabular}

Como branco, utilizou-se uma amostra de água deionizada acidificada com ácido sulfúrico até $\mathrm{pH}$ da DAM bruta que foi colocada em contato com a biomassa durante 10 minutos e seguindo as outras condições de trabalho supracitadas.

Após os tempos determinados, as amostras foram centrifugadas (12min, 2000rpm) e os precipitados lavados com água deionizada e então passaram por nova centrifugação.

Os precipitados foram secos em estufa a $60^{\circ} \mathrm{C}$ por $36 \mathrm{~h}$ e então reservados para posteriores análises de caracterização. Já os sobrenadantes foram acidificados com ácido nítrico para sua preservação e futura análise da concentração residual do metal pelo método de espectrofotometria de absorção atômica.

\subsubsection{Análise quantitativa da concentração dos metais}

O valor das concentrações residuais das espécies metálicas obtidas nos experimentos foi determinado por espectrofotometria de absorção atômica e a capacidade de captação pela biomassa Rhodococcus opacus para as correspondentes condições de equilíbrio foi determinada usando a equação 5 de balanço de massa (Equação 5): 


$$
q_{e}=\frac{\left(C_{0}-C_{e}\right) V}{M}
$$

Onde:

$\mathrm{q}_{\mathrm{e}}$ : quantidade de íon metálico captado pela biomassa $\left(\mathrm{mg} \cdot \mathrm{g}^{-1}\right)$ no equilíbrio

$\mathrm{C}_{0}$ : concentração inicial do íon metálico $\left(\mathrm{mg} \mathrm{L}^{-1}\right)$

$\mathrm{C}_{\mathrm{e}}$ : concentração do íon metálico final ou no equilíbrio $\left(\mathrm{mg} \cdot \mathrm{L}^{-1}\right)$

V: volume da solução do íon metálico (L)

$\mathrm{M}$ : massa do biossorvente $(\mathrm{g})$

\subsection{Caracterização do material biossorvente}

A biomassa foi caracterizada antes e após os ensaios de biossorção a fim de ser verificar as interações entre o material biossortivo e os elementos metálicos.

\subsubsection{Microscópio ótico}

Após crescimento a $28^{\circ} \mathrm{C}$ por $48 \mathrm{~h}$, preparou-se uma lâmina com Rhodoccocus opacus e água estéril a fim de verificar a morfologia da bactéria através da utilização de um microscópio ótico com aumento de 40 vezes.

\subsubsection{Perda ao fogo}

Fez-se o ensaio de perda ao fogo a fim de se determinar a quantidade e porcentagem de metais presentes na célula da Rhodococcus opacus.

Realizou-se o ensaio da seguinte forma: em um cadinho previamente tarado colocou-se $2 \mathrm{~mL}$ de suspensão celular, secou-se em estufa a $60^{\circ} \mathrm{C}$ por $36 \mathrm{~h}$ e pesou-se até peso constante. Colocou-se a amostra em mufla (marca Grion) a $550^{\circ} \mathrm{C}$ por $1 \mathrm{~h}$, retirou-se e após atingir temperatura ambiente pesou-se novamente 
(Figura 31). A diferença entre as massas inicial e final é a quantidade de metais presentes na amostra.

Após o ensaio de perda ao fogo (Figura 32) a amostra foi preservada para posterior análise no MEV e EDS.

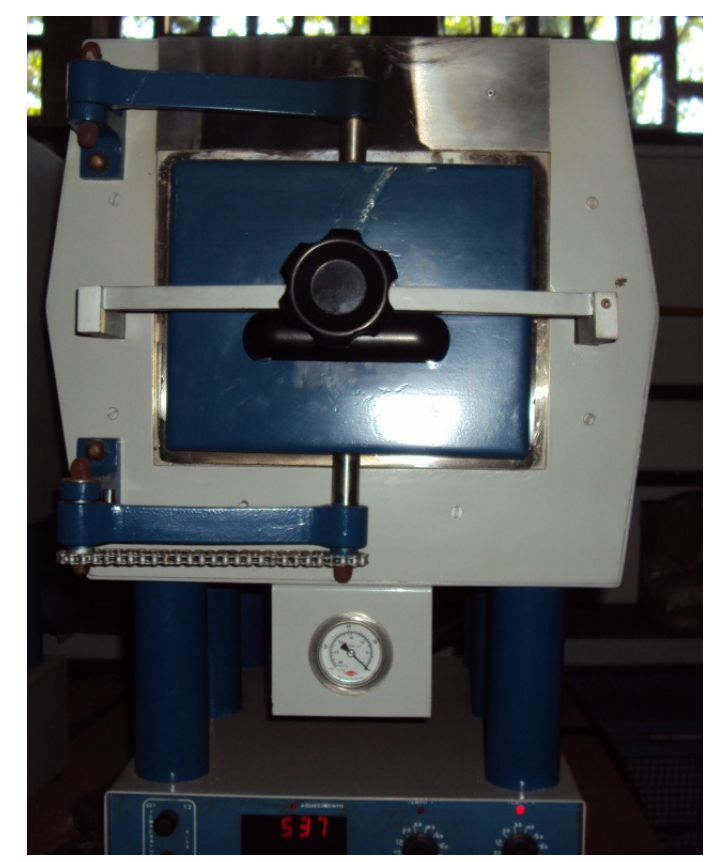

Figura 31 - Mufla Grion utilizada no ensaio de perda ao fogo.

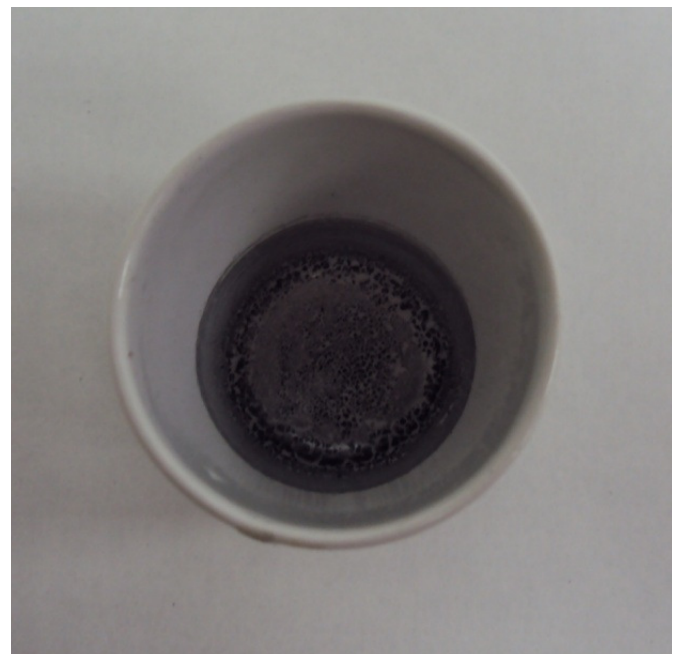

Figura 32 - Biomassa, R. opacus, após ensaio de perda ao fogo.

\subsubsection{Microscopia Eletrônica de Varredura}

O microscópio eletrônico de varredura (MEV) foi utilizado para avaliar a morfologia da biomassa após ensaio de perda ao fogo, e antes e após a sorção das diferentes espécies metálicas de modo a analisar qualitativamente o processo de biossorção, além disso, o MEV está equipado com um sistema EDS (Energy Dispersive System) o qual é capaz de detectar raios- $X$ emitidos pelas espécies durante a excitação de um feixe de elétrons. Estes raios- $X$ carregam uma energia $e$ comprimento de onda característica, cuja medida determinará a composição qualitativa e semi-quantitativa das amostras (PINO, 2005).

As amostras foram secas em estufa a $60^{\circ} \mathrm{C}$ por $36 \mathrm{~h}$ e, por não serem condutoras de corrente elétrica, precisaram ser previamente metalizadas. A 
metalização consiste na precipitação a vácuo de uma película micrométrica de ouro sobre a superfície da amostra, possibilitando a condução da corrente elétrica.

\subsubsection{Espectroscopia de Infravermelho}

Espectros no Infravermelho do Rhodooccus opacus e da biomassa carregada com os íons metálicos serão usados para comparar os grupos funcionais presentes no microrganismo antes e após interação com a DAM sintética.

Para cada amostra, uma alíquota de $1 \mathrm{mg}$ da biomassa foi homogeneizada com $100 \mathrm{mg}$ de brometo de potássio $(\mathrm{KBr})$ e prensada para preparar uma pastilha translúcida.

\subsubsection{Medições de Potencial Zeta}

A carga da superfície pode ser estabelecida pelo potencial zeta. Esta medida determina o caráter global da superfície para diferentes valores de $\mathrm{pH}$. O valor de $\mathrm{pH}$ no qual se anulam as cargas e apresenta reversibilidade (potencial zeta nulo) é chamado de ponto isoelétrico (PIE) o qual indica as características catiônicas ou aniônicas da superfície do microrganismo.

Dependendo da presença de determinados grupos funcionais presentes na superfície, estabelece-se o comportamento total da carga. Tem-se verificado que a presença de polissacarídeos determina um comportamento mais aniônico devido aos grupos fosfatos. A presença de nitrogênio das proteínas e aminas confere um comportamento mais catiônico na superfície (MOZES et al., 1989).

Medições de potencial zeta das células de $R$. opacus antes e após o contato com os íons metálicos foram realizadas utilizando o equipamento de eletroforese Zeta Meter 4.0, visando estudar o possível mecanismo de biossorção e a influência das espécies metálicas nas propriedades de superfície do microrganismo.

As amostras foram preparadas utilizando-se como eletrólito uma solução de $\mathrm{NaCl}$ 0,001M com concentração celular de $0,2 \mathrm{~g} \cdot \mathrm{L}^{-1}$ Os valore de $\mathrm{pH}$ foram corrigidos utilizando-se soluções de $\mathrm{HCl}$ e $\mathrm{NaOH}$ 0,1 e $1 \mathrm{~N}$ (BUENO, 2007). 
Os potenciais zeta foram obtidos mediante a equação de Smoluchowiski (Equação 6) tendo o valor da atividade eletroforética através de um programa computacional integrado ao aparelho (MESQUITA, 2000 apud BUENO, 2007).

$$
Z_{p}=\frac{4 \pi V_{t}}{D_{t}} \times E_{m}
$$

Onde:

$\mathrm{E}_{\mathrm{m}}$ : Mobilidade eletroforética.

$\mathrm{V}_{\mathrm{t}}$ : Viscosidade do líquido suspendido (poises) a temperatura ambiente.

$D_{\mathrm{t}}$ : Constante dielétrica.

$Z_{p}$ : Voltagem em unidades eletrostáticas. 


\section{RESULTADOS E DISCUSSÕES}

\subsection{Caracterização das DAMs reais}

Os resultados obtidos através das analises químicas estão compilados na Tabela 12. Para facilitar a visualização dos resultados e a comparação entre as amostras, estes mesmos dados foram transformados em porcentagem e estão apresentados na Figura 33.

Tabela 12 - Características das DAMs coletadas

\begin{tabular}{|c|c|c|}
\hline & \multicolumn{2}{|c|}{ Concentração (mg. $\left.\mathrm{L}^{-1}\right)$} \\
\hline & EDR3 & SS16 \\
\hline $\mathrm{pH}$ & 2,50 & 3,05 \\
\hline Al & 427,00 & 269,00 \\
\hline $\mathrm{Ca}$ & 1609,33 & 143,07 \\
\hline Cd & ND & ND \\
\hline $\mathrm{Cr}$ & 0,02 & 0,01 \\
\hline $\mathrm{Cu}$ & 0,05 & 0,03 \\
\hline $\mathrm{Fe}$ & 127,80 & 0,65 \\
\hline $\mathbf{K}$ & 1738,52 & 64,07 \\
\hline Li & 139,56 & ND \\
\hline Mg & 154,53 & 19,24 \\
\hline Mn & 5,45 & 1,12 \\
\hline $\mathrm{Na}$ & 61,00 & 30,04 \\
\hline $\mathbf{N i}$ & 0,37 & 0,16 \\
\hline $\mathbf{P b}$ & ND & ND \\
\hline $\mathrm{Zn}$ & 8,58 & 0,49 \\
\hline $\mathrm{Cl}^{-}$ & 1513,42 & 69,76 \\
\hline $\mathrm{NO}^{3-}$ & 908,18 & 50,65 \\
\hline $\mathrm{SO}_{4}{ }^{-2}$ & 3671,45 & 518,28 \\
\hline
\end{tabular}



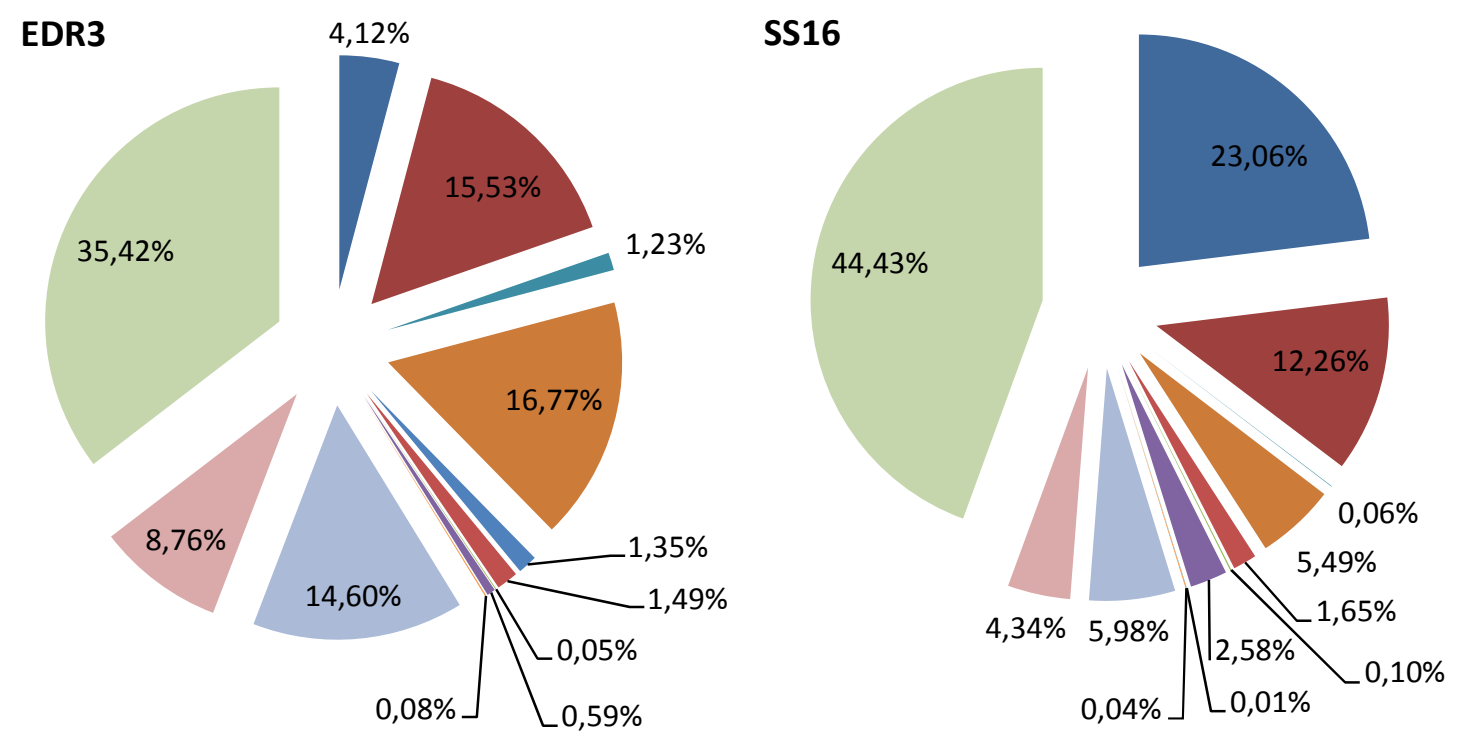

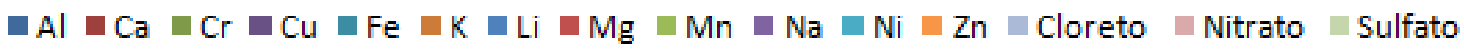

Figura 33 - Caracterização das amostras EDR3 e SS16 em porcentagem

Observando-se a Tabela 12 e a Figura 33 (à esquerda), verificamos que na DAM EDR os elementos com maiores concentrações são os ânions sulfato e nitrato que somados correspondem a mais de $42 \%$ do total de substâncias presentes nesta amostra. Cloreto, Ca e K possuem concentrações em torno de $15 \mathrm{mg} \cdot \mathrm{L}^{-1}$ enquanto que amônio e Al apresentam-se em torno de $4 \mathrm{mg} \cdot \mathrm{L}^{-1}$ cada. Já a concentração de $\mathrm{Fe}$ e $\mathrm{Mg}$ gira em torno de $1,3 \mathrm{mg} \cdot \mathrm{L}^{-1}$, os teores de $\mathrm{Na}, \mathrm{Ni}$, Mn e $\mathrm{Zn}$ são menores que $1 \mathrm{mg} \cdot \mathrm{L}^{-1}$ e a soma dos mesmos não totaliza $1 \%$ da composição da amostra.

De acordo com a Tabela 12 e a Figura 33 (à direita) verifica-se que na amostra SS16 as concentrações de Fe, Zn e Ni são menores que $1 \mathrm{mg}^{-1} \mathrm{~L}^{-1}$ e o teor de Ca e $\mathrm{Al}$ correspondem a $35 \%$ do total. A concentração de $\mathrm{Mn}$ é menor que $10 \mathrm{mg} \cdot \mathrm{L}^{-1}$, a de $\mathrm{Na}$ é igual a $30,04 \mathrm{mg} \cdot \mathrm{L}^{-1}$ e a de $\mathrm{K}$ encontra-se em torno de $60 \mathrm{mg} \cdot \mathrm{L}^{-1}$. A concentração de cloreto e nitrato somam um pouco mais de $10 \%$ do total e a concentração de sulfato $\left(518,28 \mathrm{mg} \cdot \mathrm{L}^{-1}\right)$, apesar de baixa quando comparada com a da EDR3 $\left(3671,45 \mathrm{mg} \cdot \mathrm{L}^{-1}\right)$, representa mais de $40 \%$ da composição total.

Os metais $\mathrm{Cr}$, Cu e $\mathrm{Ni}$ (os dois primeiros na amostra SS16) não constam na Figura 33 porque estão presentes em concentrações menores do que $0,01 \%$. A ausência de Li na amostra SS16 e mesmo a concentração dos elementos em 
comum, também diferem entre as amostras. Essas diferenças podem ser relacionadas com a qualidade e composição da matéria-prima extraída (camada de onde o carvão foi extraído, geologia local), com os tipos de rochas e mineral no local de formação e passagem da DAM, uma vez que a mesma é capaz de lixiviar os elementos presentes no minério e nas rochas circundantes à área minerada (CAMPANER \& SILVA, 2009).

Além disso, a amostra SS16 é proveniente de uma boca de mina abandonada enquanto que a DAM EDR3 é proveniente da coleta das drenagens de toda a unidade carbonífera, ou seja, também das pilhas de rejeitos do carvão que estão expostos diretamente a intempéries e sabe-se que a pirita quando em contato com ar (oxigênio) e água oxida-se e inicia reações de hidrólise que produzem sulfato férrico $\left(\mathrm{Fe}_{2}\left(\mathrm{SO}_{4}\right)_{3}\right)$ e íons livre de hidrogênio $\left(\mathrm{H}^{+}\right)$, acidificando ainda mais o meio (KONTOPOULOS, 1998; GAIKWAD \& GUPTA, 2008)

Em ambas as amostras, EDR3 e SS16, a substância com maior concentração é o sulfato, proveniente das reações de oxidação dos minérios. O baixo pH, está relacionado com a presença de íons livre de hidrogênio $\left(H^{+}\right)($GAIKWAD \& GUPTA, 2008).

A grande diferença na concentração de $\mathrm{Fe}$ entre as duas amostras pode ser explicada a partir da análise das reações envolvidas na formação da DAM apresentadas anteriormente. Desta análise observa-se que a Equação 3 que converte o $\mathrm{Fe}^{+2}$ a Fe ${ }^{+3}$ retroalimentando a Equação 2 ocorre pela ação das bactérias acidofílicas, que de acordo com Rao (2006) e Garcia Jr. (1995), tais bactérias vivem e crescem somente em meio ácido, com pH variando entre 1,5 e 3. Desta forma, explica-se a menor quantidade de Fe total encontrada na amostra SS16, pois esta amostra apresentou-se com pH igual a 3,05, que justifica uma menor quantidade ou mesmo ausência de bactérias acidofílicas que promovam a retroalimentação da reação.

A porcentagem de $\mathrm{Cr}, \mathrm{Cu}, \mathrm{Pb}, \mathrm{Ni}, \mathrm{Mn}$ e $\mathrm{Zn}$ apesar de baixa em relação a concentração total (menor que 0,1\%) devem ser consideradas, pois estes metais representam riscos a saúde e ao meio ambiente.

O efluente resultante precisa estar de acordo com a legislação vigente para disposição de efluentes industriais (CONAMA 357/2005) e o lodo gerado na neutralização da DAM, segundo Neto et al., (2005), é classificado conforme a NBR 10004/2004, como Resíduo não Inerte - Classe IIA e portanto sua disposição 
em aterros exige a impermeabilização com argila e geomembrana de PEAD (polietileno de alta densidade), sistema de drenagem e tratamento dos efluentes além de um programa de monitoramento.

\subsection{Caracterização da cepa}

\subsubsection{Microscópio ótico}

Conforme descrito por Finnerty (1992), as bactérias do gênero Rhodococcus podem variar morfologicamente de cocos a pequenos bastonetes, durante seu ciclo de crescimento. Tal constatação pode ser visualizada na Figura 34, na qual é possível visualizar a morfologia da Rhodoccus opacus vista em microscópio ótico com aumento de 40 vezes.

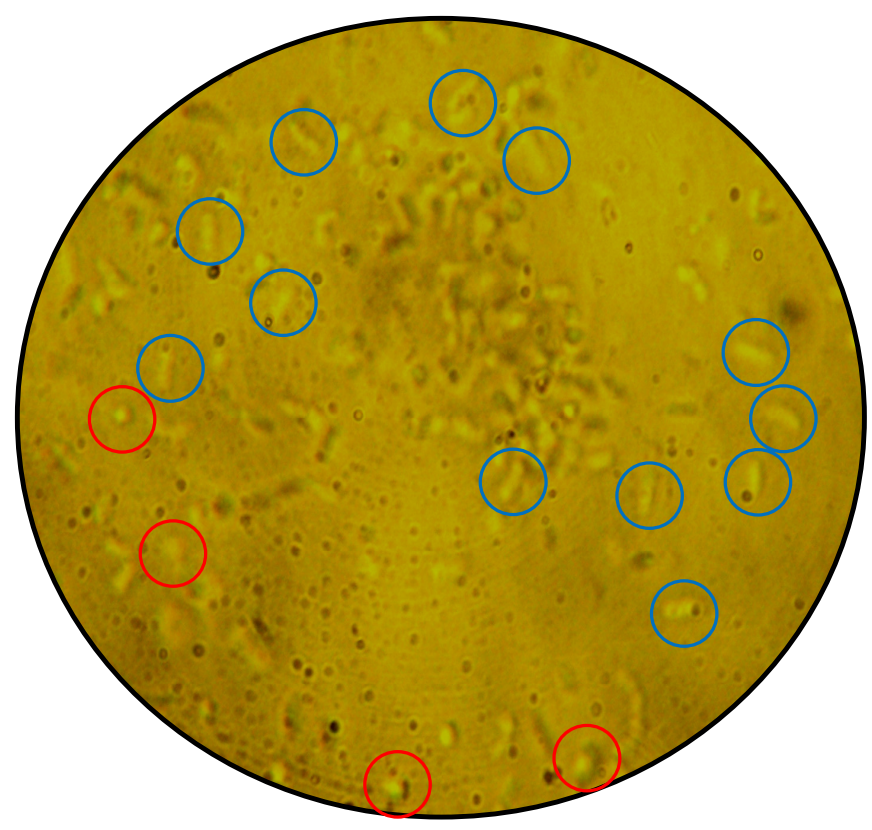

Figura 34 - Rhodococcus opacus visto em microscópio ótico.

Para facilitar a visualização na Figura 34, os coccus estão circulados em vermelho e os bastonetes em azul. Nesta mesma figura, verificamos a presença predominante de bastonetes na cepa utilizada. 


\subsubsection{Preparo do biossorvente}

O precipitado, proveniente do crescimento da Rhodococcus opacus após lavagem e centrifugação, pode ser descrito como um sólido fino, com coloração bege acinzentada e heterogênea (Figura 35).
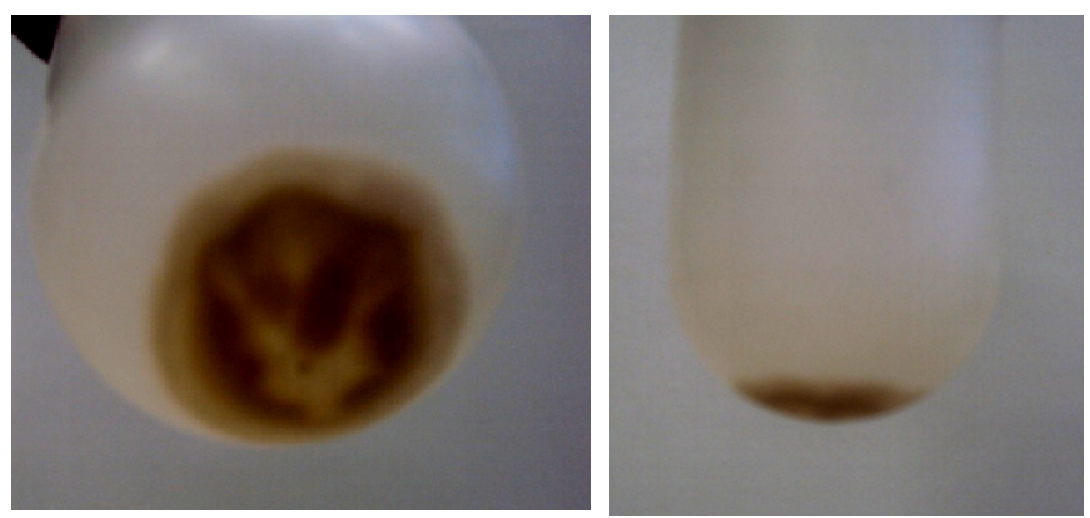

Figura 35 - Precipitado obtido na centrifugação após lavagem.

Quando comparado com resultados obtidos na literatura (BUENO, 2007; VÁSQUEZ, 2005) verifica-se que existem outras colorações para precipitados de Rhodococcus opacus. Na Figura 36 é possível observar duas outras cepas com características diferentes: em " $A$ " o sólido apresenta-se na coloração vermelho e em "B" é bege.

Segundo Cánovas, Gracía-Cases \& Iborra (1997), uma outra representante do gênero Rhodococcus, a Rhodococcus fascians, pode apresentar parede celular com diferentes colorações: laranja, branca, rosa, entre outras. As mudanças dependem do meio e das condições de crescimento. 

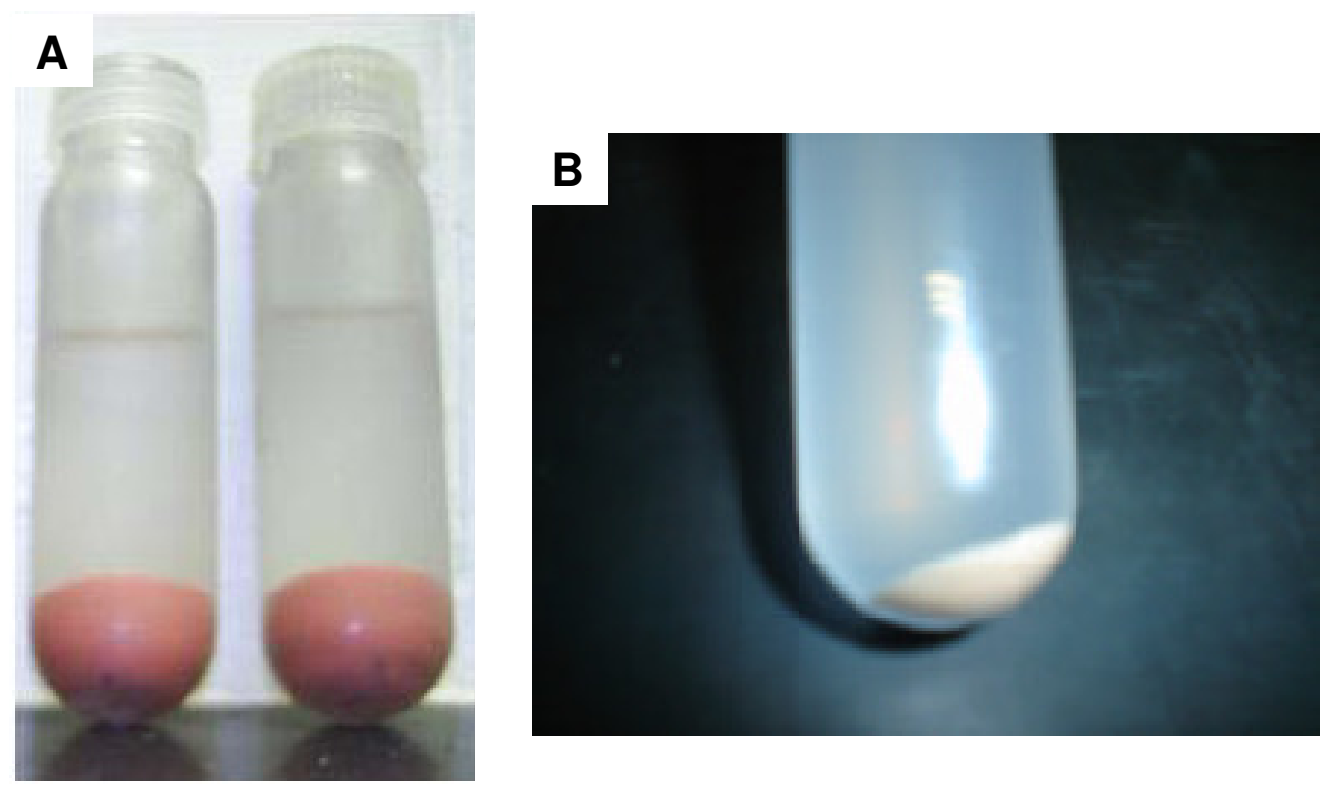

Figura 36 - Rhodococcus opacus após centrifugação: A) BUENO, 2007; B) VÁSQUEZ, 2005

\subsection{Caracterização da biomassa antes da biossorção}

\subsubsection{Ensaio de perda ao fogo}

Na Tabela 13 encontram-se os valores coletados no ensaio de perda ao fogo. A partir deles é possível assumir que a massa inicial e final de biossorvente é 53 e $1 \mathrm{mg}$, respectivamente. Com esses dados determinou-se que a biomassa possui aproximadamente 1,9\% (em peso) de metais em sua composição elementar.

Tabela 13 - Dados coletados no ensaio de perda ao fogo

\begin{tabular}{rc|ccc}
\hline \multicolumn{5}{c}{ Massa $(\mathbf{g})$} \\
\hline $\begin{array}{c}\text { Tara Cadinho } \\
18,7129\end{array}$ & $\mathbf{1}^{\text {a }}$ pesagem & $\mathbf{2}^{\text {a }}$ pesagem & $\mathbf{3}^{\text {a }}$ pesagem & $\mathbf{4}^{\text {a }}$ pesagem \\
& 18,7662 & 18,7139 & 18,7138 & 18,7138 \\
& & & & Massa final $\mathbf{0 , 0 0 1}$ \\
\hline
\end{tabular}




\subsubsection{MEV e EDS}

Imagens da Rhodococcus opacus são apresentadas nas Figuras 37 e 38. Ambas as fotos foram tiradas utilizando-se detector secundário uma vez que este é indicado quando se deseja avaliar a topografia do material. Os pontos mais claros nas imagens indicam a presença de material condutor (falhas durante 0 recobrimento com ouro) ou são efeitos de borda. Ainda na Figura 38 podemos observar que a Rhodococcus apresenta comprimento em torno de $2 \mu \mathrm{m}$.

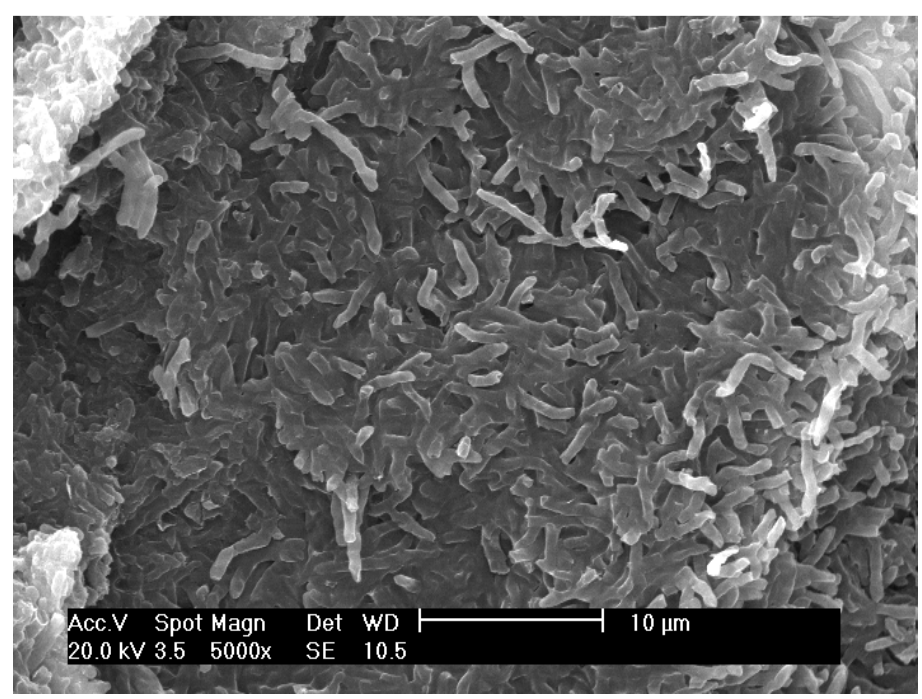

Figura 37 - Imagem de elétrons secundários da Rhodococcus opacus.

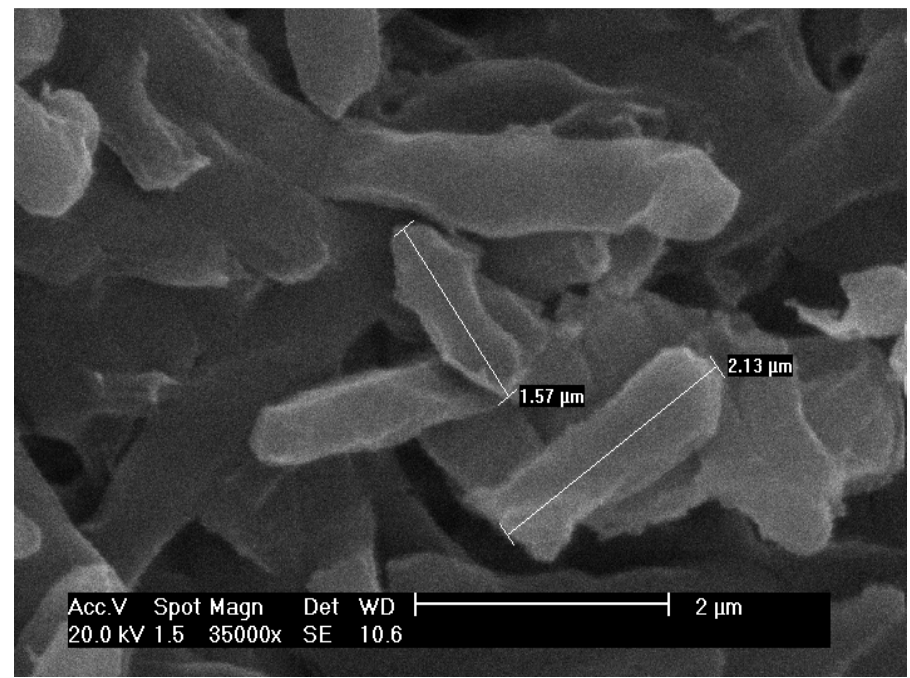

Figura 38 - Imagem de elétrons secundários do tamanho da Rhodococcus opacus. 
Na Figura 39 A, B e C, são apresentadas micrografias da Rhodococcus opacus encontradas na literatura (BUENO, 2007; VÁSQUEZ, 2005; ALVAREZ et al., 2004).

Ao compararem-se as imagens obtidas neste trabalho com as da Figura 39, é possível observar células com diferentes morfologias: na Figura $39 \mathrm{~B}$ e $\mathrm{C}$ as células possuem formato de bastonetes, já na Figura $39 \mathrm{~A}$, o mesmo não ocorre, pois neste caso as células se apresentam em forma de cocos. Ainda assim, os resultados estão de acordo com a literatura, pois segundo Finnerty (1992), as bactérias do gênero Rhodococcus podem variar morfologicamente de cocos a pequenos bastonetes.
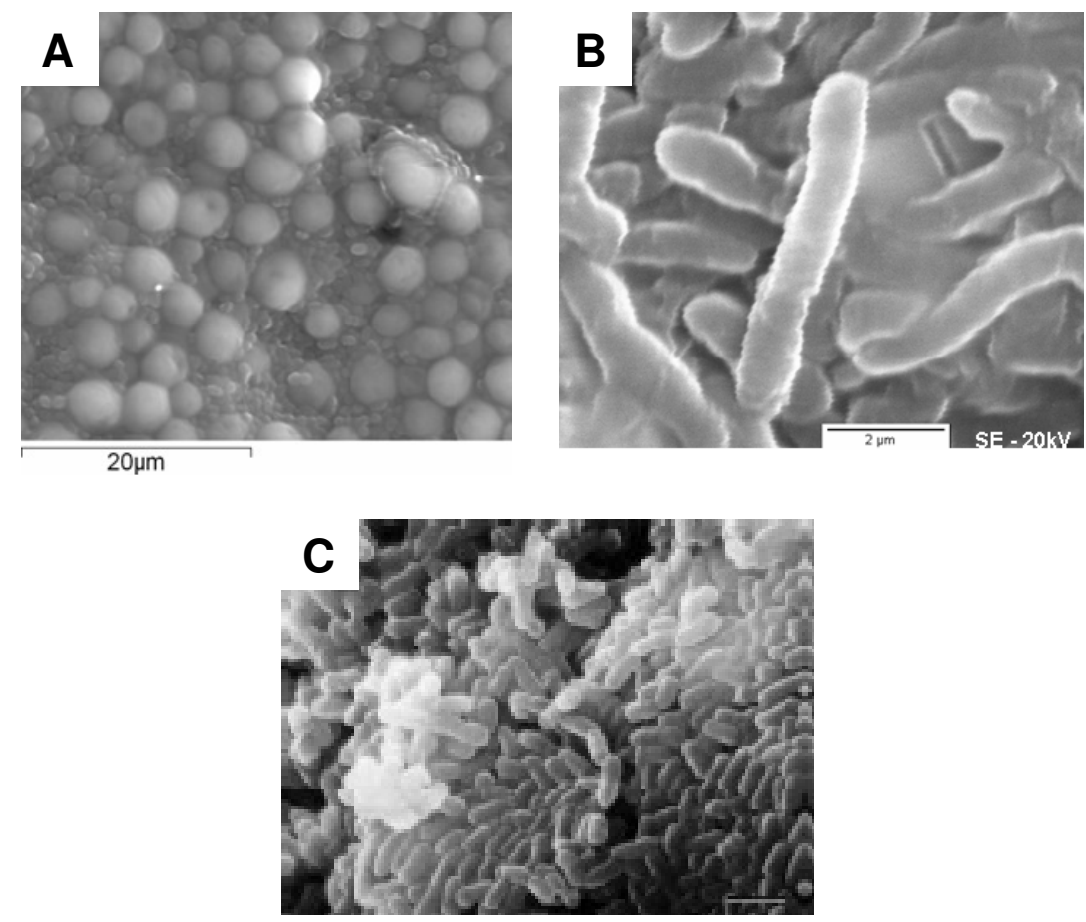

Figura 39 - Imagens da Rhodococcus opacus obtidas por MEV: A) BUENO, 2007; B) VÁSQUEZ, 2005; e C) ALVAREZ et al., 2004.

A partir da análise do EDS da Rhodococcus opacus (Figura 40) pode-se afirmar que o elemento com maior concentração é o carbono (76\%) seguido de oxigênio (14\%), fósforo (6\%), e potássio (3\%). Os teores de $\mathrm{Mg}$, Ca e $\mathrm{Fe}$ juntos não representam nem $1 \%$ do total de elementos presentes na amostra. A presença de ouro é devido ao prévio recobrimento da amostra com este metal. A composição elementar qualitativa encontrada confere com dados bibliográficos, uma vez que a parede celular de bactérias gram-positivas é composta por peptidoglicano, ácidos teicóico e teiurônico, fosfolipídios e proteínas (VOLESKY, 2007). 
O peptideoglicano corresponde a um esqueleto, formado por dois derivados de açúcares, a N-acetilglicosamina (NAG) e o ácido N-acetilmurâmico (NAM), unidos alternadamente, através de ligações do tipo B-1,4. O grupo carboxil de cada molécula de NAM liga-se a um tetrapeptídeo, composto por aminoácidos que alternam-se nas configurações L e D. O ácido teicóico corresponde a polímeros de glicerol ou ribitol ligados a açúcares ou aminoácidos e conectados entre si por meio de grupamentos fosfato. Porém, em casos de escassez de fosfato, os ácidos teicóicos podem ser substituídos por ácidos teiurônicos (KYAW, 2010).

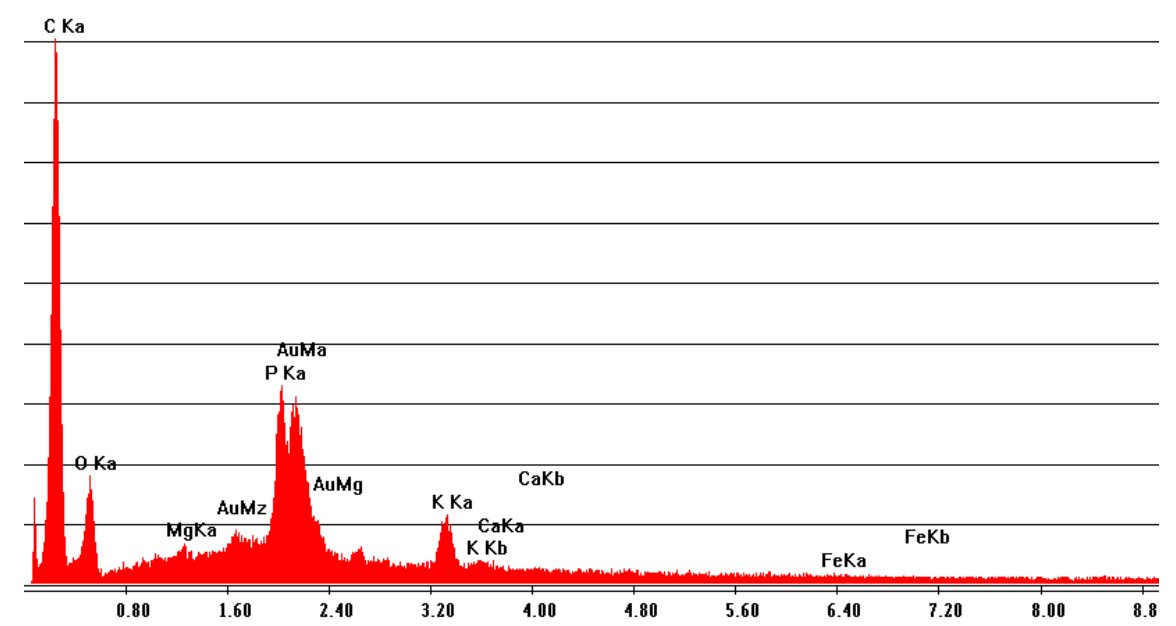

Figura 40 - EDS, Rhodococcus opacus.

As Figuras 41 e 42 são EDS retirados da literatura (BUENO, 2007; VÁSQUEZ, 2005). Nas imagens podem-se observar a presença de picos semelhantes aos obtidos neste trabalho de $\mathrm{K}, \mathrm{P}$ em ambas as literaturas. Outros picos como de $\mathrm{C}$ e $\mathrm{O}$ só estão presentes na Figura 41. A diversidade dos metais pode ser explicada pelas condições de cultivo e idade da cepa. 


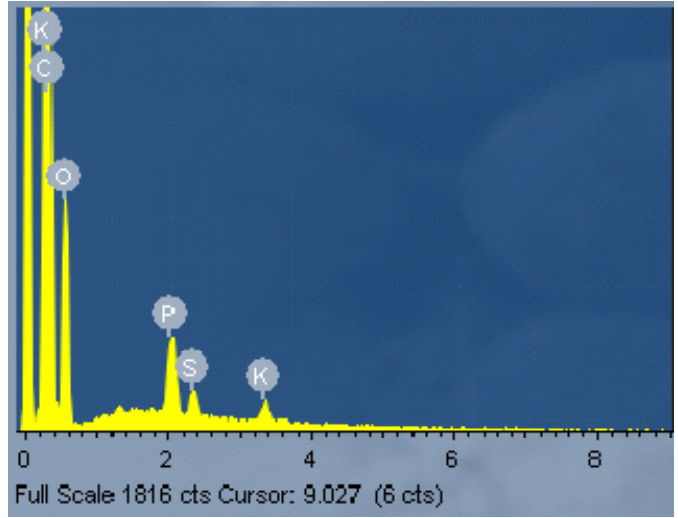

Figura 41 - EDS, Rhodococcus opacus (adaptado de BUENO, 2007).

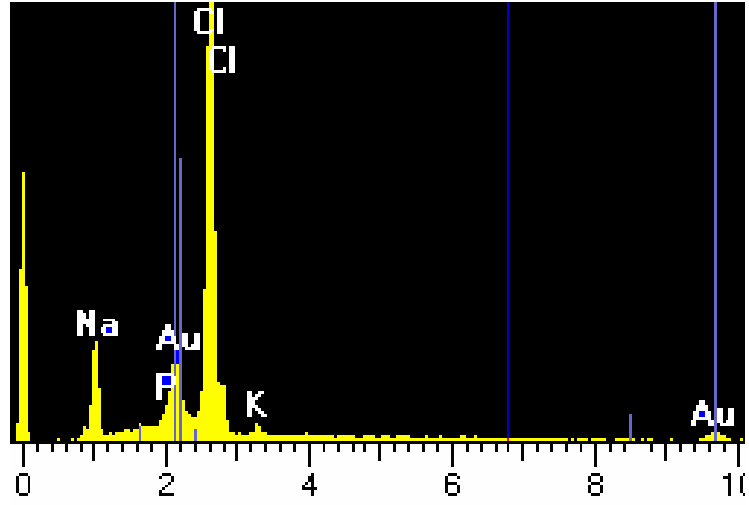

Figura 42 - EDS, Rhodococcus opacus (adaptado de VÁSQUEZ, 2005)

Após o ensaio de perda ao fogo, analisou-se a amostra através de MEV e EDS, os resultados encontram-se nas Figuras 43, 44 e 45.

A amostra foi analisada utilizando-se detector retroespalhado uma vez que o interesse era determinar as diferenças de peso atômico. O incremento da coloração (das regiões mais claras para as mais escuras) esta diretamente ligado ao incremento do peso atômico (dos mais pesados para os mais leves). Deve-se observar que as regiões com coloração preto/cinza chumbo entre as partículas do material corresponde à fita utilizada na preparação da amostra.

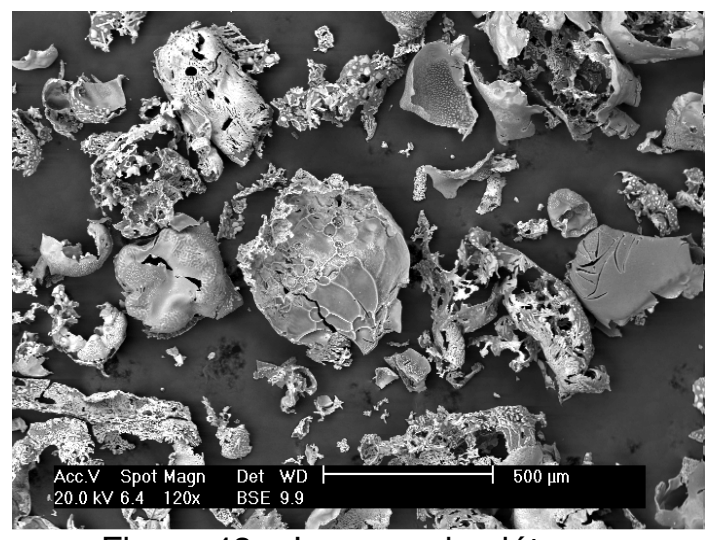

Figura 43 - Imagem de elétrons retroespalhados da Rhodococcus opacus após ensaio de perda ao fogo.

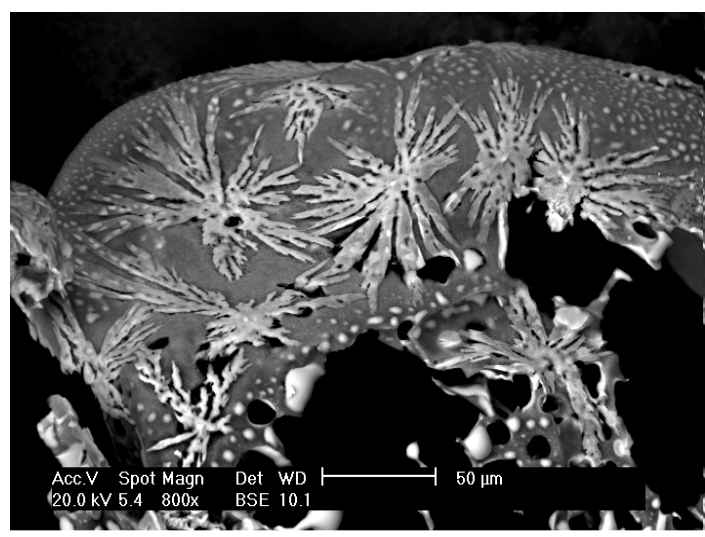

Figura 44 - Imagem de elétrons retroespalhados da Rhodococcus opacus após ensaio de perda ao fogo

Como esperado, não há presença de oxigênio no EDS da amostra após ensaio de perda ao fogo (Figura 45), e a presença de carbono deve-se à composição da fita utilizada no preparo das amostras. Mais de 50\% das cinzas obtidas após submissão da Rhodococcus opacus a $550^{\circ} \mathrm{C}$, é fósforo. A concentração de potássio é de aproximadamente $30 \%$, a de cálcio $6,6 \%$, a de ferro 
$4 \%$ e a de magnésio 3,6\%. Os valores corroboram as informações obtidas no EDS da Rhodococcus opacus antes do ensaio de perda ao fogo, já que os metais estão presentes praticamente nas mesmas proporções.

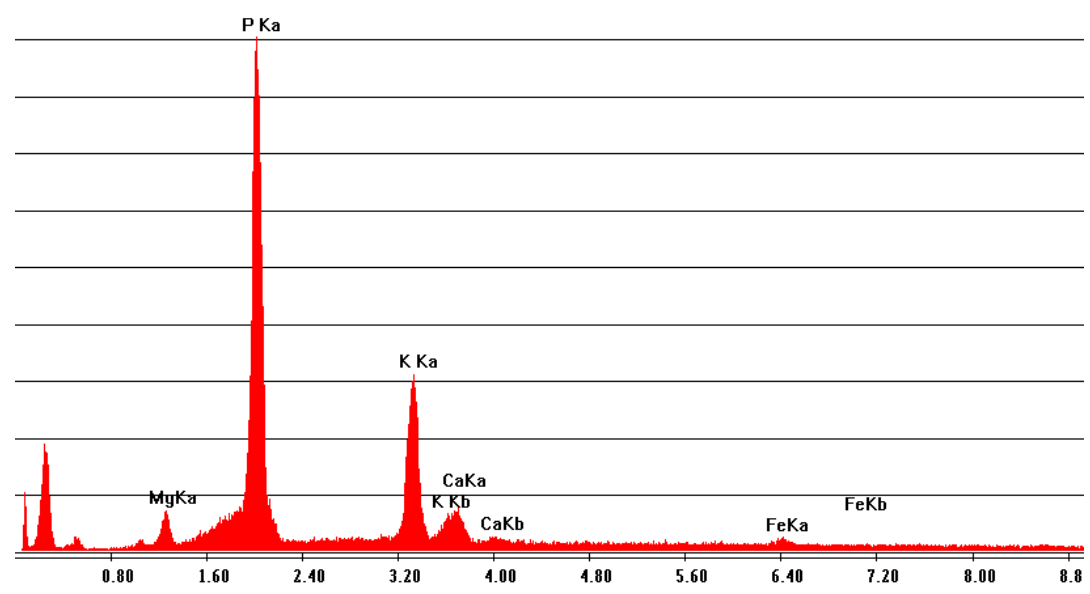

Figura 45 - EDS, Rhodococcus opacus após ensaio de perda ao fogo.

\subsubsection{Espectroscopia de infravermelho}

A identificação dos grupos funcionais presentes na biomassa bruta, ou seja, antes do contato com os íons, foi feita através da comparação das bandas de absorção de infravermelho obtidas no ensaio com as encontradas na literatura conforme Tabela 14. 
Tabela 14- Relação entre as bandas de absorção de infravermelho e grupos funcionais.

\begin{tabular}{|c|c|c|}
\hline Grupos Funcionais correspondentes & $\begin{array}{l}\text { Comprimento } \\
\text { de onda }\left(\mathrm{cm}^{-1}\right)\end{array}$ & Referência \\
\hline -OH estiramento do grupo $-\mathrm{NH}$ & $\approx 3350$ & $\begin{array}{c}\text { Ashkenazy, Gottlieb \& } \\
\text { Yannai, } 1997\end{array}$ \\
\hline - $\mathrm{NH}$ estiramento assimétrico $-\mathrm{NH}_{2}$ & $\approx 3298$ & $\begin{array}{l}\text { Sharma, } 2001 \text { apud Botero, } \\
\text { Torem \& Mesquita, } 2008\end{array}$ \\
\hline - $\mathrm{NH}$ estiramento simétrico $-\mathrm{NH}_{2}$ & 3072 & $\begin{array}{l}\text { Sharma, } 2001 \text { apud Botero, } \\
\text { Torem \& Mesquita, } 2008\end{array}$ \\
\hline - $\mathrm{CH}$ estiramento assimétrico $-\mathrm{CH}_{3}$ & 2959 & $\begin{array}{l}\text { Sharma, } 2001 \text { apud Botero, } \\
\text { Torem \& Mesquita, } 2008\end{array}$ \\
\hline$-\mathrm{CH}$ estiramento assimétrico do $\mathrm{CH}_{2}$ & 2922 & Yun et al, 2001 \\
\hline - $\mathrm{CH}$ estiramento assimétrico do $\mathrm{CH}_{2}$ & 2934 & $\begin{array}{l}\text { Sharma, } 2001 \text { apud Botero, } \\
\text { Torem \& Mesquita, } 2008\end{array}$ \\
\hline - $\mathrm{CH}$ estiramento simétrico do $\mathrm{CH}_{2}$ & 2875 & $\begin{array}{l}\text { Sharma, } 2001 \text { apud Botero, } \\
\text { Torem \& Mesquita, } 2008\end{array}$ \\
\hline$-\mathrm{CH}$ estiramento simétrico do $\mathrm{CH}_{2}$ & 2858 & Yun et al, 2001 \\
\hline $\mathrm{C}=\mathrm{O}$ & $1750-1620$ & $\begin{array}{l}\text { Sharma, } 2001 \text { apud Botero, } \\
\text { Torem \& Mesquita, } 2008\end{array}$ \\
\hline $\begin{array}{l}-\mathrm{NH}_{2} \text { flexão do grupo amida primária ou } \\
-\mathrm{NH}_{3} \text { aminas ácidas }\end{array}$ & 1682 & $\begin{array}{l}\text { Sharma, } 2001 \text { apud Botero, } \\
\text { Torem \& Mesquita, } 2008\end{array}$ \\
\hline (R-CO) $\mathrm{NH}_{2}$ grupo amida primária & $\approx 1658$ & Yun et al, 2001 \\
\hline$(\mathrm{R}-\mathrm{CO})_{2} \mathrm{NHCH}$ grupo amida secundária & 1539 & Yun et al, 2001 \\
\hline$-\mathrm{CH}_{3}$ e $-\mathrm{CH}_{2}$ & $1452-1390$ & $\begin{array}{l}\text { Sharma, } 2001 \text { apud Botero, } \\
\text { Torem \& Mesquita, } 2008\end{array}$ \\
\hline $\mathrm{C}=\mathrm{O}$ estiramento simétrico do $\mathrm{COO}^{-}$ & $\approx 1400$ & Kapoor \& Viraraghavan, 1997 \\
\hline $\mathrm{P}=\mathrm{O}$ estiramento simétrico do $\mathrm{PO}_{2}^{-}$ & $1250-1220$ & Kapoor \& Viraraghavan, 1997 \\
\hline$-\mathrm{CN}$ & 1072 & Kapoor \& Viraraghavan, 1997 \\
\hline$-\mathrm{CH}$ & $\approx 666$ & Selatnia et al., 2004 \\
\hline
\end{tabular}

Os grupos funcionais possivelmente presentes na biomassa Rhodococcus opacus antes da biossorção estão identificados no espectro da Figura 46. 


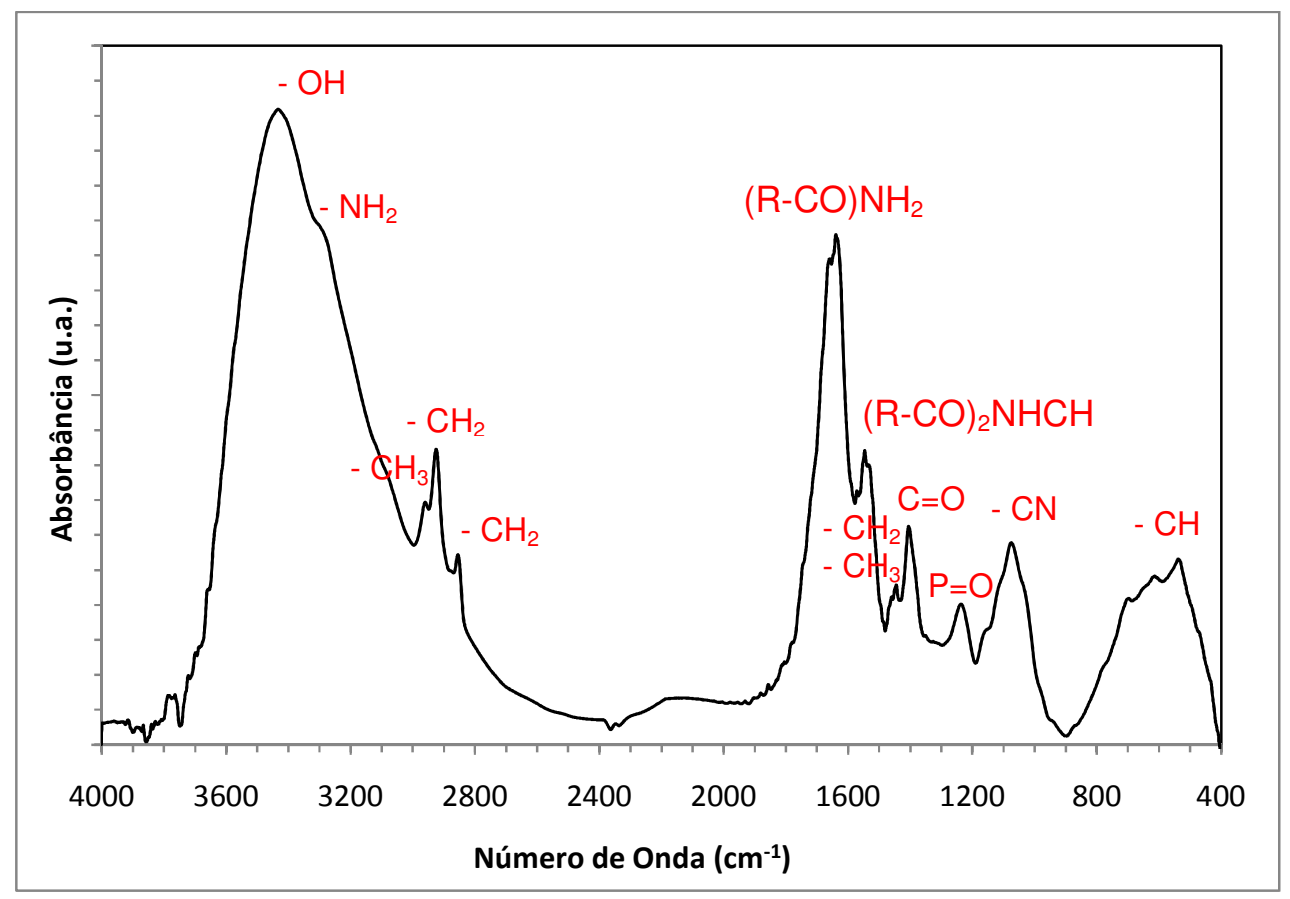

Figura 46 - Espectro da Rhodococcus opacus antes da biossorção obtido em infravermelho.

A hidroxila $(-\mathrm{OH})$ e o estiramento $\mathrm{N}-\mathrm{H}$ compõe açúcares e proteínas, respectivamente (ASHKENAZY, GOTTLIEB \& YANNAI, 1997), assim como a ligação covalente formada por C-N é proveniente da fração protéica (KAPOOR \& VIRARAGHAVAN, 1997), outros grupos funcionais estão presentes nos constituintes da parede celular de bactérias gram-positivas, como é o caso da Rhodococcus opacus aqui estudada.

Os grupos identificados na Figura 46 condizem com a formação da parede celular de bactérias gram-positivas, onde:

1) As proteínas, presentes na superfície externa da célula, são compostas por aminoácidos, moléculas formadas por carbono, hidrogênio, oxigênio e nitrogênio, unidos através de ligações peptídicas, onde o grupo carboxilia $(-\mathrm{COOH})$ reage com o grupo amina (- $\mathrm{NH}_{2}$ ou $\left.-\mathrm{NH}-\right)$ de outra molécula resultando em uma ligação covalente C-N. O grupo funcional obtido é uma amida [(-CO) $\mathrm{NH}_{2}$ ou $\left.(-\mathrm{CO})_{2} \mathrm{NH}\right]$.

2) O peptidoglicano, responsável pela rigidez da parede celular, é constituído por açúcares (moléculas formadas por carbono, hidrogênio e oxigênio com a presença de hidroxilas $(-\mathrm{OH}))$ e aminoácidos.

3) $\mathrm{O}$ ácido teicóico é formado por polímeros de glicerol ou ribitol (moléculas compostas por carbono hidrogênio e oxigênio com a presença de três 
hidroxilas, o primeiro, e cinco hidroxilas o ribitol) ligados a açúcares ou aminoácidos e conectados entre si por meio de grupamentos fosfato.

Os fosfolipídios, principais componentes das membranas celulares, são formados pela união de um grupo fosfato a um gliceridio, sendo que o ultimo é formado pela combinação de ácido graxo (moléculas compostas por carbono, hidrogênio e oxigênio que apresentam o grupo carboxila $(-\mathrm{COOH})$.

$\mathrm{Na}$ Figura 47 verifica-se que resultados semelhantes foram encontrados por Bueno (2007) para Rhodococcus opacus.

Selatnia et al. (2004) também depararam-se com resultados similares para Streptomyces rimosus que, assim como a $R$. opacus, também é uma bactéria aeróbia pertencente ao grupo dos actinomicetos (Figura 48).

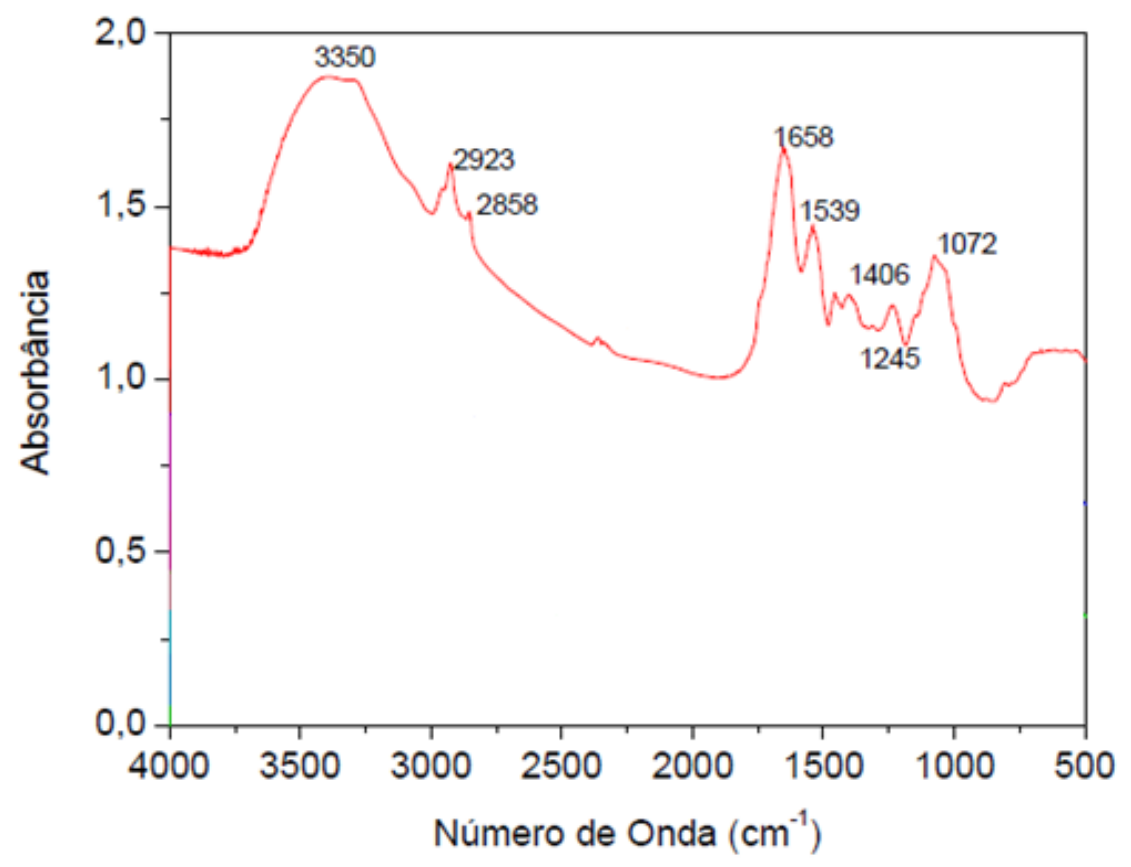

Figura 47 - FT-IR espectro da biomassa Rhodococcus opacus Antes do contato com os íons (adaptado de Bueno, 2007) 


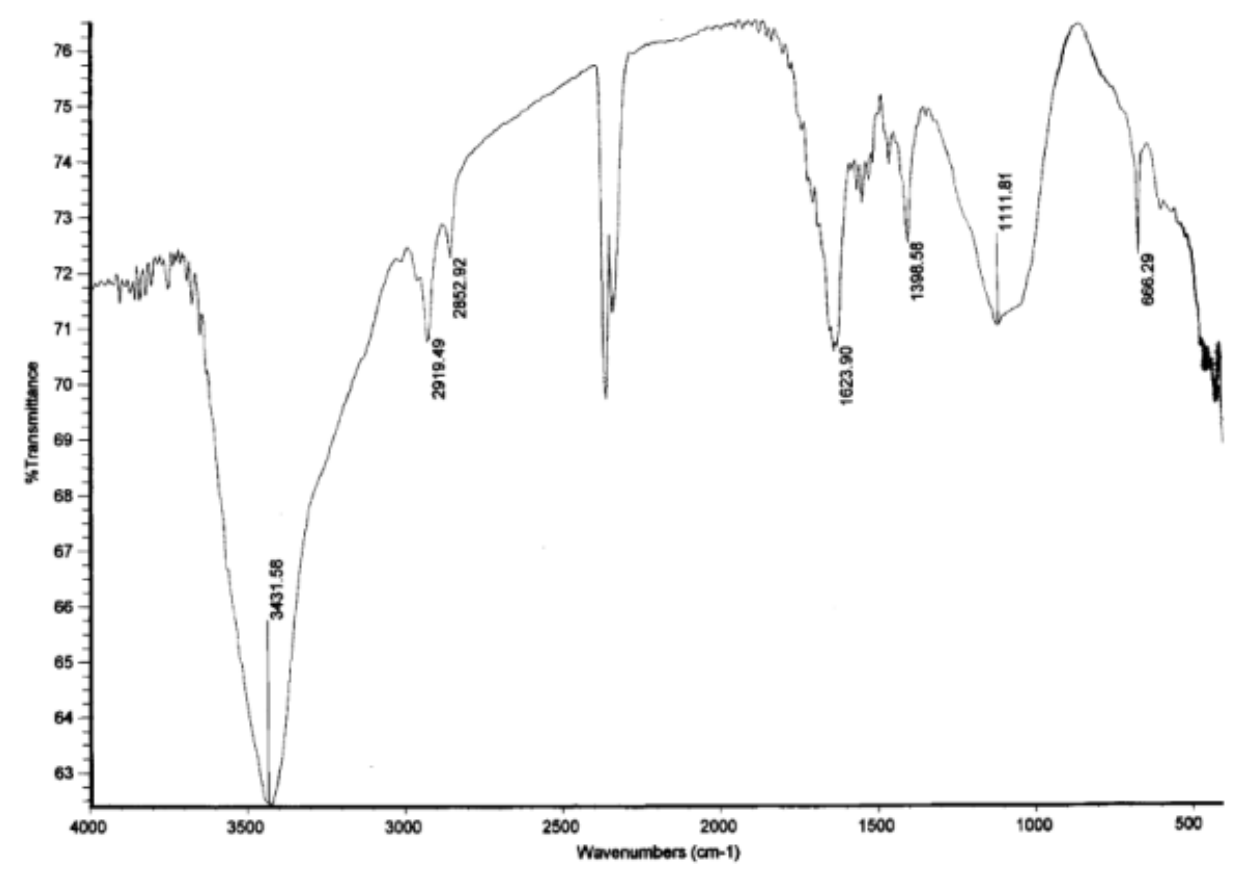

Figura 48 - FT-IR espectro da biomassa Streptomyces rimosus sem tratamento e antes do contato com os íons

(Selatnia et al.,2004)

\subsection{Efeito do tempo de sorção}

\subsubsection{Estudos Cinéticos}

Através do estudo da cinética de adsorção é possível identificar os mecanismos envolvidos e, assim, determinar as condições ótimas do processo de remoção dos metais.

Para identificar o equilíbrio do sistema, desenha-se a quantidade de íons captada $\left(\mathrm{q}_{\mathrm{e}}\right)$, ou a porcentagem de remoção em função do tempo de contato ( $\mathrm{t}$ ), sendo que o mesmo é alcançado quando não ocorre sorção adicional (Figura 49).

Os valores utilizados na construção da curva de sorção foram obtidos no ensaio de "determinação do tempo ótimo" para a DAM nas seguintes condições: $\mathrm{pH}$ 2,6; concentração inicial dos metais: semelhante a DAM bruta; agitação: 175rpm; temperatura $25^{\circ} \mathrm{C}$; concentração de biomassa: $1 \mathrm{~g} \cdot \mathrm{L}^{-1}$. 


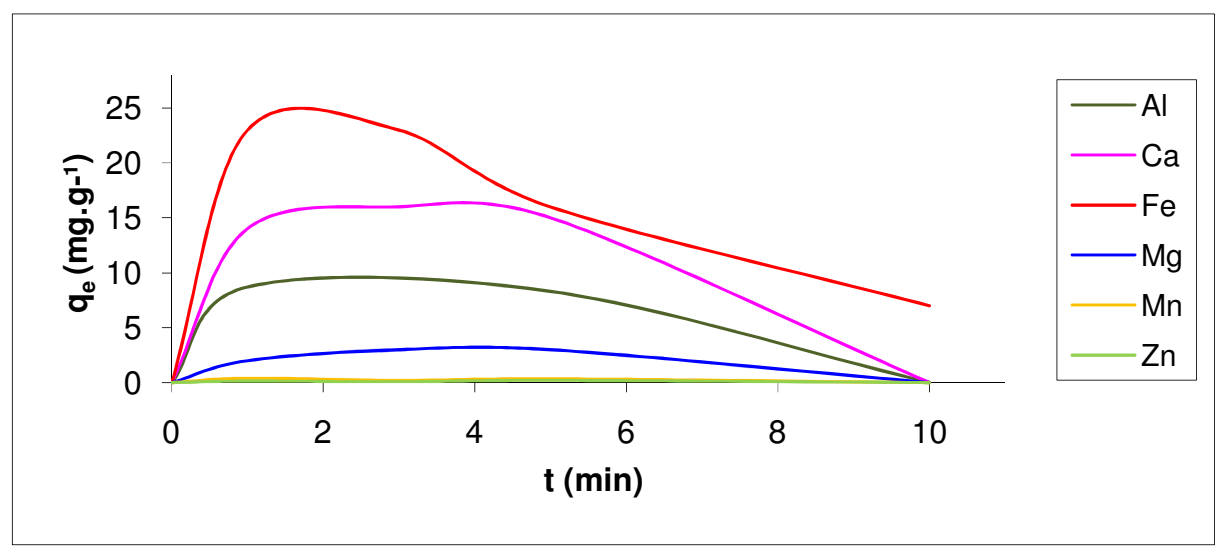

Figura 49 - Perfil do tempo na biossorção dos íons da solução sintética DAM WEI bruta (pH 2,6; temperatura $25^{\circ} \mathrm{C}$ ).

Devido a concentração de $\mathrm{Cu}$ e $\mathrm{Ni}$ em solução, menor que $1 \mathrm{mg} \cdot \mathrm{L}^{-1}$, optou-se por desconsiderar a presença dos mesmos.

O equilíbrio é alcançado em cerca de 1 minuto e a máxima captação dos metais seguiu a mesma ordem da concentração inicial ( $\mathrm{Ca} \rightarrow \mathrm{Fe} \rightarrow \mathrm{Al} \rightarrow \mathrm{Mg} \rightarrow \mathrm{Mn}$ $\rightarrow \mathrm{Zn}$ ). Assim, os metais que estavam em maior concentração foram os que tiveram maior captação, com exceção do cálcio: $\mathrm{Fe} \rightarrow \mathrm{Ca} \rightarrow \mathrm{Al} \rightarrow \mathrm{Mg} \rightarrow \mathrm{Mn} \rightarrow \mathrm{Zn}$. Porém, proporcionalmente (considerando a concentração inicial versus a quantidade captada) o metal com maior remoção foi o $\mathrm{Mn}$, seguido pelo $\mathrm{Fe}, \mathrm{Ca}, \mathrm{Al}, \mathrm{Zn}$ e Mg.

Até o momento, dos metais estudados neste trabalho, apenas o $\mathrm{Al}$ e $\mathrm{Zn}$ já foram temas de outros autores (CAYLLAHUA, CARVALHO \& TOREM, 2009; VÁSQUEZ, 2005) utilizando a mesma biomassa, ainda assim sempre em soluções monoelementares. Comparando com os valores obtidos por Cayllahua, Carvalho \& Torem (2009), para a captação de Al, o resultado obtido neste trabalho foi cerca de 4 vezes maior. Já para a captação de Zn estudado por Vásquez (2005), a remoção é 4 vezes maior do que a obtida neste trabalho, em ambos os casos o $\mathrm{pH}$ empregado foi 3 , a concentração de biomassa $2 \mathrm{~g} \cdot \mathrm{L}^{-1}$ e a concentração das soluções metálicas eram de $50 \mathrm{mg} . \mathrm{L}^{-1}$ e $20 \mathrm{mg} . \mathrm{L}^{-1}$, para o $\mathrm{Al}$ e o $\mathrm{Zn}$, respectivamente. Apesar de não ter utilizado estes metais, Bueno (2007) verificou que em sistemas ternários a Rhodococcus opacus apresenta diferentes graus de afinidade pelos metais e a quantidade de metal captado para sistemas mono e multielementares é diferente.

Em soluções, os íons metálicos não estão necessariamente livres, pois podem haver interações entre co-íons e com isso a formação de complexos. A ocorrência dessas reações depende de fatores como: concentração, temperatura, 
força iônica, pH e potencial da solução. Sabe-se que a captação dos metais ocorre em dois processos: primeiramente acontecem interações estequiométricas entre o metal e os grupos químicos reativos da biomassa e, então, ocorre a deposição do metal. Contudo, geralmente, em soluções com baixo $\mathrm{pH}$ predominam íons livres (VOLESKY, 1989).

Ainda assim, acredita-se que a remoção do ferro pode ter sido facilitada pela formação de hidróxido férrico e, sua conseqüente precipitação sobre a biomassa. Uma vez que o íon $\mathrm{Fe}^{2+}$ em presença de ar pode ser oxidado a $\mathrm{Fe}^{3+}$ e este pode precipitar na forma de hidróxido férrico em pH em torno de 3 (VOLESKY, 1989). Este hidróxido tende a precipitar e agir na co-precipitação de outros íons presentes na solução (POSSA \& dos SANTOS, 2003).

Outro fator que está relacionado com a captação de metais é seu potencial iônico. Este é determinado pela carga e pelo raio iônico do metal.

Segundo Jirgensons \& Straumanis (1962), a adsorção de íons por carvão mineral ativado segue certa seqüência, tanto para cátions $(\mathrm{H} \rightarrow \mathrm{Ba} \rightarrow \mathrm{Sr} \rightarrow \mathrm{Ca} \rightarrow \mathrm{Mg}$ $\rightarrow \mathrm{Rb} \rightarrow \mathrm{K} \rightarrow \mathrm{Na} \rightarrow \mathrm{Li}$ ), quanto para ânions $\left(\mathrm{OH} \rightarrow \mathrm{CNS} \rightarrow \mathrm{I} \rightarrow \mathrm{Br} \rightarrow \mathrm{Cl} \rightarrow \frac{1}{2} \mathrm{SO}_{4}\right)$. A adsorção dos cátions inicia-se com íons multivalentes seguindo para os monovalentes de maior raio iônico. Já para a adsorção dos anions, é o oposto, os íons univalentes com maior raio são adsorvidos mais fortemente, seguidos pelos com menor raio e finalmente os multivalentes. Contudo, este mesmo comportamento não foi estabelecido neste trabalho. $\mathrm{Na}$ Tabela 15, os metais são apresentados segundo os seguintes parâmetros: raio iônico, raio atômico, raio covalente, eletronegatividade e massa molar. A ordem de apresentação segue sempre do menor para o maior.

Tabela 15 - Metais segundo algumas características físicas

\begin{tabular}{l|c}
\hline \multicolumn{1}{c|}{ Propriedade } & Metais \\
\hline Raio iônico & $\mathrm{Al} \rightarrow \mathrm{Mg} \rightarrow \mathrm{Zn} \rightarrow \mathrm{Fe} \rightarrow \mathrm{Mn} \rightarrow \mathrm{Ca}$ \\
Raio atômico & $\mathrm{Fe} \rightarrow \mathrm{Zn} \rightarrow \mathrm{Mn} \rightarrow \mathrm{Al} \rightarrow \mathrm{Ca} \rightarrow \mathrm{Mg}$ \\
Raio covalente & $\mathrm{Fe} \rightarrow \mathrm{Mn} \rightarrow \mathrm{Zn}, \mathrm{Al} \rightarrow \mathrm{Ca} \rightarrow \mathrm{Mg}$ \\
Eletronegatividade & $\mathrm{Ca} \rightarrow \mathrm{Mg} \rightarrow \mathrm{Al} \rightarrow \mathrm{Fe}, \mathrm{Mg} \rightarrow \mathrm{Zn}$ \\
Massa atômica & $\mathrm{Mg} \rightarrow \mathrm{Al} \rightarrow \mathrm{Ca} \rightarrow \mathrm{Mn} \rightarrow \mathrm{Fe} \rightarrow \mathrm{Zn}$ \\
\hline
\end{tabular}


Avaliando a remoção global, ou seja, considerando a somatória de todos os metais, no equilíbrio do sistema a captação dos íons é 48,2mg.g ${ }^{-1}$ (Figura 50).

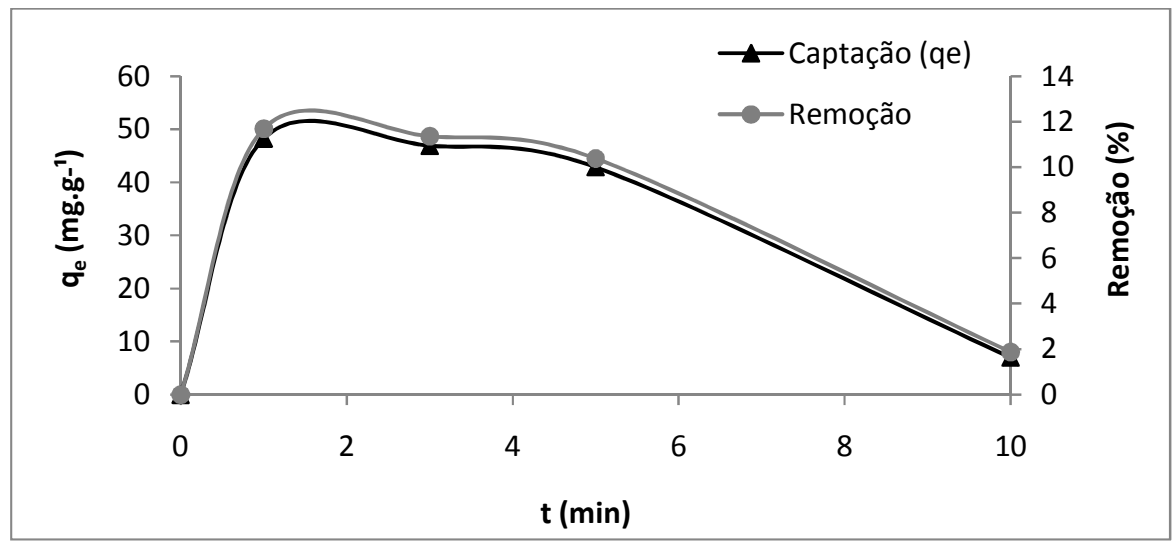

Figura 50 - Perfil do tempo na biossorção dos íons da solução sintética DAM WEI bruta (pH 2,6; concentração celular $1 \mathrm{~g} \cdot \mathrm{L}^{-1}$; temperatura $\left.25^{\circ} \mathrm{C}\right)$.

Após 5 minutos de reação, as captações dos íons diminuíram e aproximaram-se de zero. Segundo Bueno (2007), o soluto (íons metálicos) previamente sorvido tende a dessorver e voltar para a solução com o avanço da reação. Além disso, verificou-se através de imagens obtidas no MEV que após dez minutos de contato há o rompimento da parede celular e a exposição dos metais para o meio (Figuras 98, 103 e 104 detalhes no próximo capítulo).

A interação entre os metais e a biomassa envolve tanto processos químicos como físicos e por isso para investigar qual(is) o(s) mecanismo(s) dominante(s) na cinética da reação é necessário encontrar qual a etapa que controla a biossorção.

Neste sentido, as etapas do processo biossortivo podem ser divididas basicamente em dois grupos: baseadas nos fenômenos de difusão ou, as baseadas nos mecanismos de acumulação.

A difusão pode ocorrer de três diferentes maneiras:1) Difusão no líquido (difusão do soluto da solução até o filme liquido que circunda o adsorvente); 2) Difusão externa (difusão do filme liquido para a superfície da biomassa; e 3) Difusão interna (difusão do soluto da superfície do adsorvente para as regiões intraparticulares). Sendo que a difusão no liquido, quando utilizada agitação suficiente para evitar gradientes de concentração na solução, em geral, não é uma etapa limitante do processo. 
Ainda há uma quarta etapa que reúne os mecanismos de sorção físicoquímica, troca iônica, precipitação, complexação (BUENO, 2007).

Para avaliar a cinética de sorção obtida experimentalmente é possível aplicar alguns modelos matemáticos pré-definidos a fim de determinar quais as principais etapas do processo.

O efeito da difusão externa foi avaliado utilizando-se a Equação 7, na qual considera-se que a concentração na superfície do adsorvente tende a zero e que a difusão intraparticula pode ser desprezada (GUIBAL, MILOT \& TOBIN, 1998).

$$
\ln \frac{C_{t}}{C_{0}}=-K_{f} \times \frac{s}{V} \times t
$$

onde:

$\mathrm{C}_{0}$ - concentração inicial do metal $\left(\mathrm{mg} \cdot \mathrm{L}^{-1}\right)$;

$\mathrm{C}_{\mathrm{t}}$ - concentração num tempo qualquer $\left(\mathrm{mg} \cdot \mathrm{L}^{-1}\right)$;

$\mathrm{K}_{\mathrm{f}}$ - é uma constante da equação;

$\mathrm{S}$ - área superficial do sorvente $\left(\mathrm{m}^{2}\right)$;

$\mathrm{V}$ - volume da solução (L).

Na Figura 51 encontram-se as curvas para o modelo de difusão externa aplicado a biossorção e, nas Figuras 52, 53, 54, 55, 56 e 57 a linearização deste mesmo modelo.

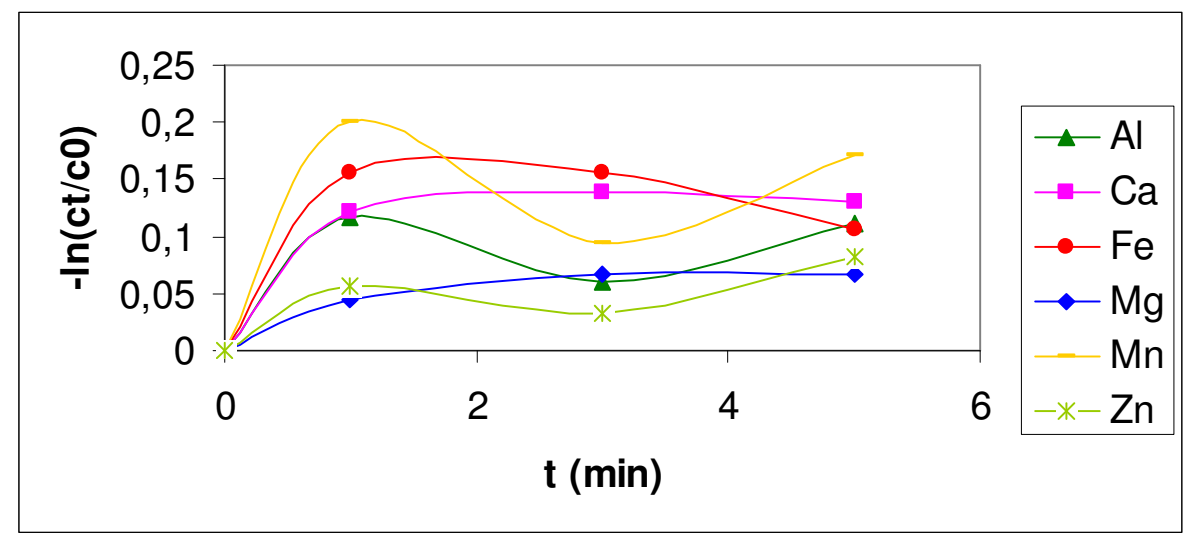

Figura 51 - Modelo de difusão externa aplicado a biossorção. 


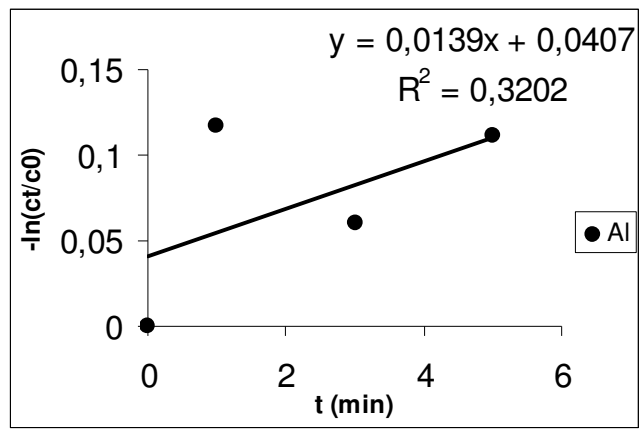

Figura 52 - Linearização do modelo de difusão externa para o Al na presença dos co-ions.

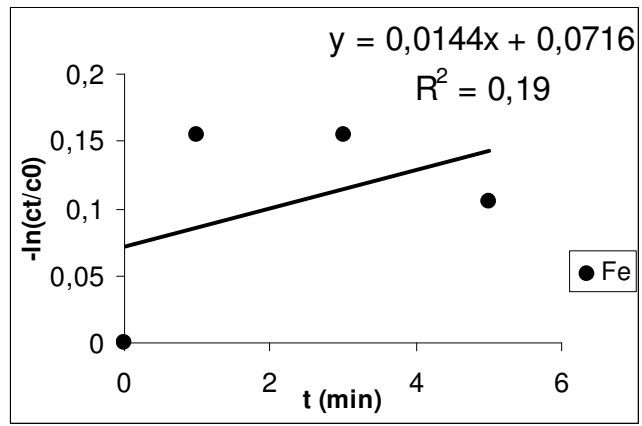

Figura 54 - Linearização do modelo de difusão externa para o Fe na presença dos co-ions.

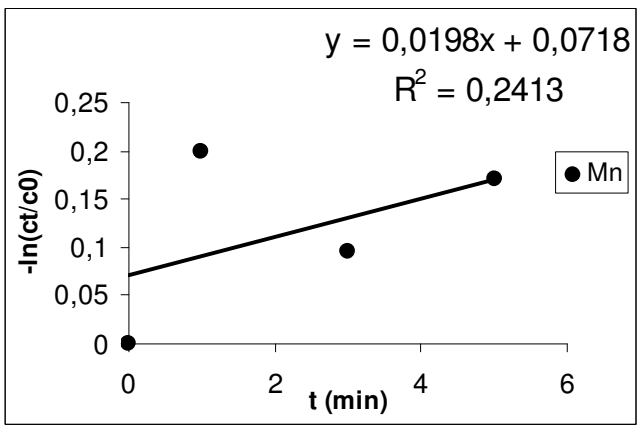

Figura 56 - Linearização do modelo de difusão externa para o Mn na presença dos co-ions.

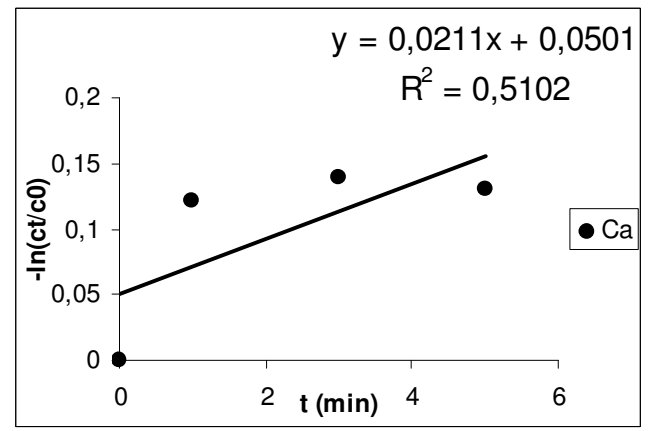

Figura 53 - Linearização do modelo de difusão externa para o Ca na presença dos co-ions.

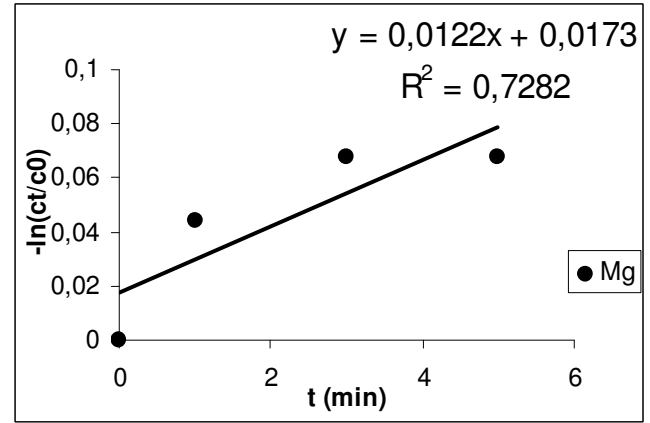

Figura 55 - Linearização do modelo de difusão externa para o Mg na presença dos co-ions.

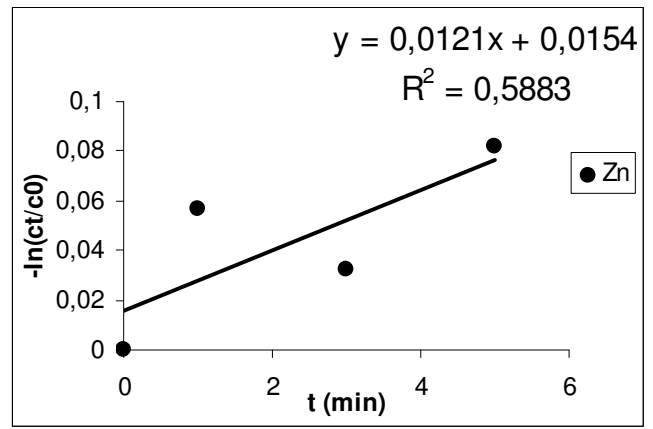

Figura 57 - Linearização do modelo de difusão externa para o Zn na presença dos co-ions

Analisando os coeficientes de correlação das equações $\left(R^{2}\right)$, que estão na faixa de 0,19 a 0,72, conclui-se que a difusão externa não é a etapa dominante no processo para nenhum dos metais estudados. Bueno (2007), chegou a mesma 
conclusão estudando a captação de $\mathrm{Pb}(\mathrm{II}), \mathrm{Cu}(\mathrm{II})$ e $\mathrm{Cr}(\mathrm{III})$ por Rhodococcus opacus, porém utilizando sistemas monoelementares.

A fim de avaliar a ação da difusão intraparticula utilizou-se a Equação 8. Neste caso, considera-se que o mecanismo de adsorção é controlado pela difusão no adsorvente e por difusão convectiva na solução (GUIBAL, MILOT \& TOBIN, 1998).

$$
q_{t}=f \times\left(t^{0,5}\right)
$$

Onde:

$\mathrm{q}_{\mathrm{t}}$ - acumulação na superfície da biomassa)

f - constante de velocidade de difusão intra-partícula

$\mathrm{t}$ - tempo

Nessa equação a taxa inicial pode ser calculada a partir da dependência de $q_{t}$ e o parâmetro $\left(D_{t} / r^{20,5}\right)$, onde $r$ é o raio da partícula e $D$ é a difusidade da partícula dentro do soluto.

$\mathrm{Na}$ Figura 58 encontram-se as curvas para o modelo de difusão interna aplicado a biossorção e, nas Figuras 59, 60, 61, 62, 63 e 64 a linearização deste mesmo modelo.

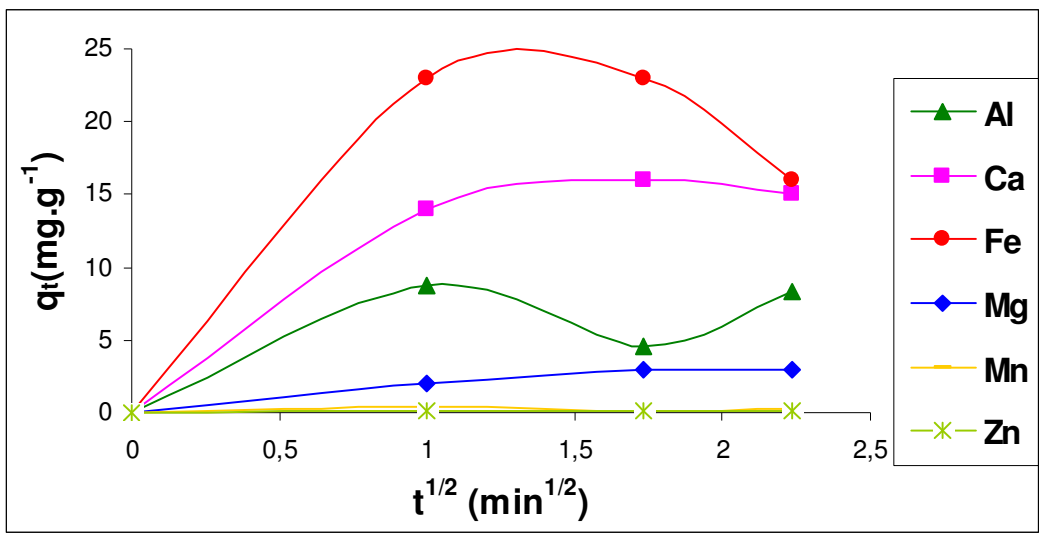

Figura 58 - Modelo de difusão interna aplicado a biossorção. 


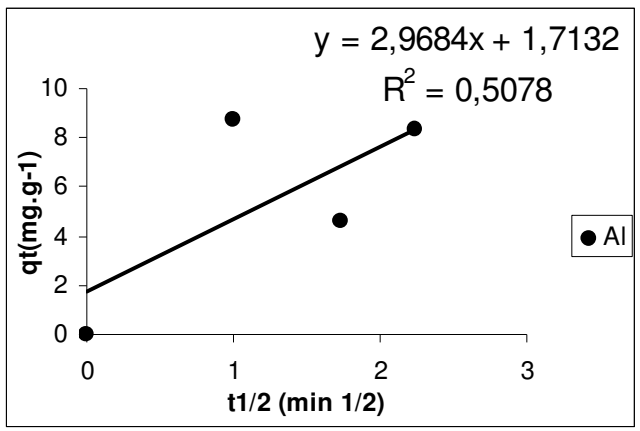

Figura 59 - Linearização do modelo de difusão interna para o Al na presença dos co-ions.

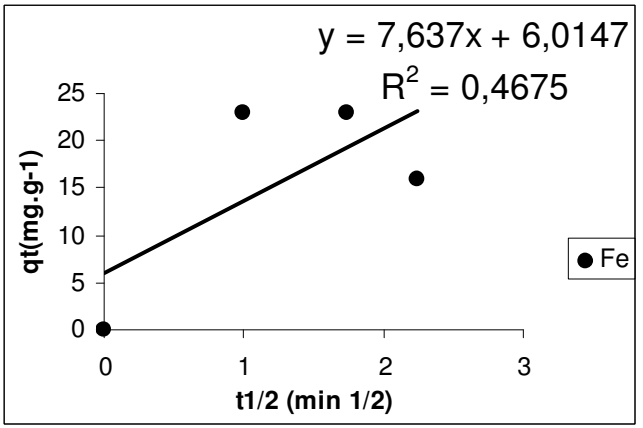

Figura 61 - Linearização do modelo de difusão interna para o Fe na presença dos co-ions.

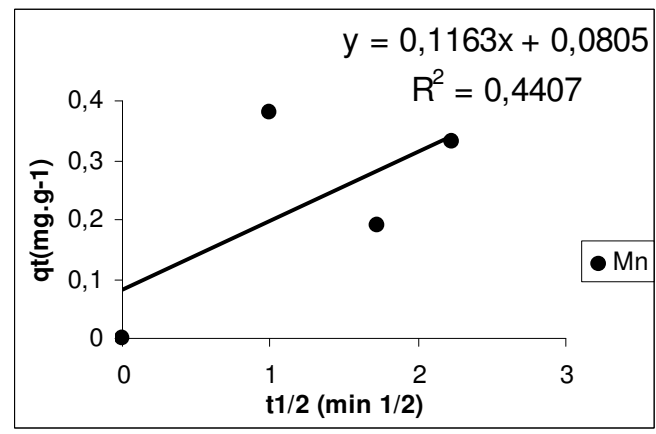

Figura 63 - Linearização do modelo de difusão interna para o $\mathrm{Mn}$ na presença dos co-ions.

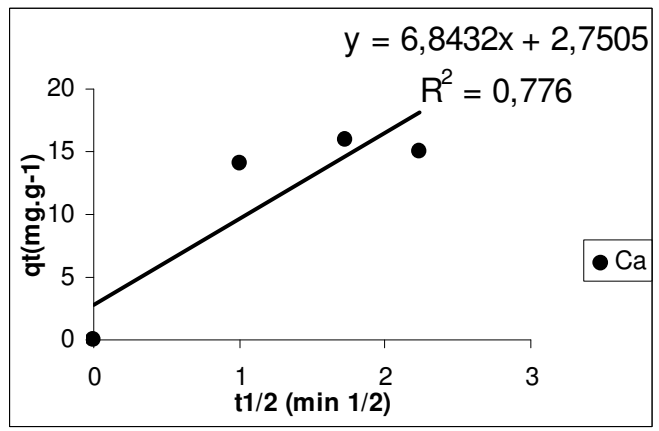

Figura 60 - Linearização do modelo de difusão interna para o Ca na presença dos co-ions.

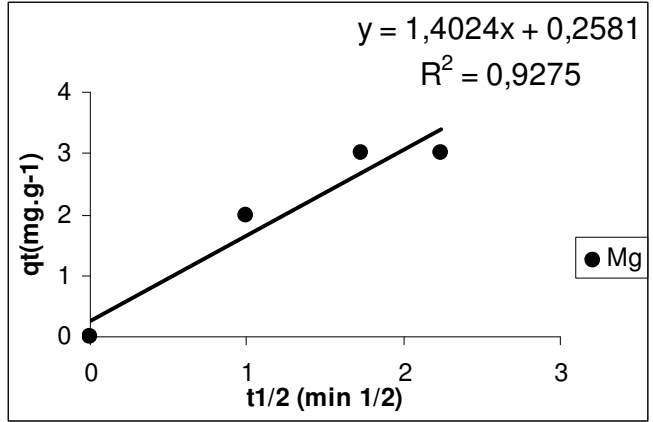

Figura 62 - Linearização do modelo de difusão interna para o Mg na presença dos co-ions.

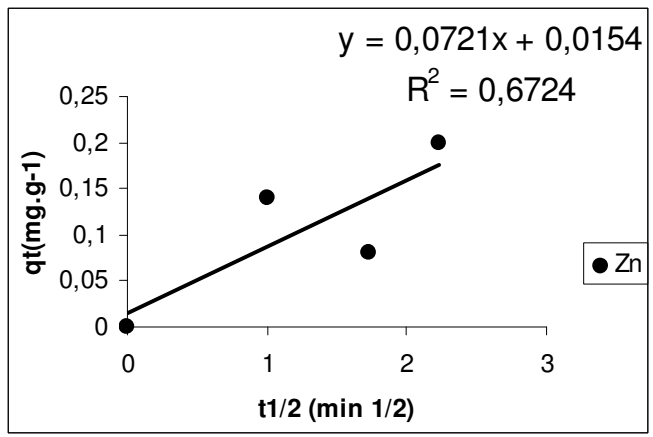

Figura 64 - Linearização do modelo de difusão interna para o Zn na presença dos co-ions.

Observa-se que o mecanismo de difusão intraparticula também não é a etapa determinante do processo para nenhum dos metais, já que o coeficiente de correlação é sempre menor que 0,7 . 
Com os resultados apresentados até o momento através da aplicação das Equações 7 e 8 (difusão externa e interna, respectivamente), percebe-se que a transferência de massa não parece ser limitante no processo de adsorção dos íons metálicos pela biomassa.

Dentre os modelos cinéticos propostos para identificar a ordem da reação em sistemas biossortivos, as equações de primeira (9) e de segunda ordem (10 e 11) são as mais empregadas (FEBRIANTO et al., 2009.)

$$
\begin{gathered}
\log \left(q_{e}-q_{t}\right)=\log \left(q_{e}\right)-\frac{K_{L}}{2,303} t \\
\frac{1}{q_{t}}=\frac{1}{v_{0}}+\frac{1}{q_{e}} t \\
v_{0}=K q_{e}{ }^{2}
\end{gathered}
$$

Onde:

qe - quantidade de íons metálicos captados no equilíbrio qt - quantidade de íons metálicos captados em um tempo $t$ $\mathrm{KL}$ - constante de velocidade de pseudo-primeira ordem $\mathrm{v} 0$ - velocidade em $\mathrm{t}=0$

$\mathrm{K}$ - constante de velocidade de pseudo-segunda ordem

Na Figura 65, observa-se a aplicação do modelo cinético de pseudo-primeira ordem e, nas figuras seguintes (Figuras 66, 67, 68, 69, 70 e 71), tem-se as equações e os coeficientes de correlação entre a linha de tendência e os pontos obtidos experimentalmente nos ensaios biossortivos. 


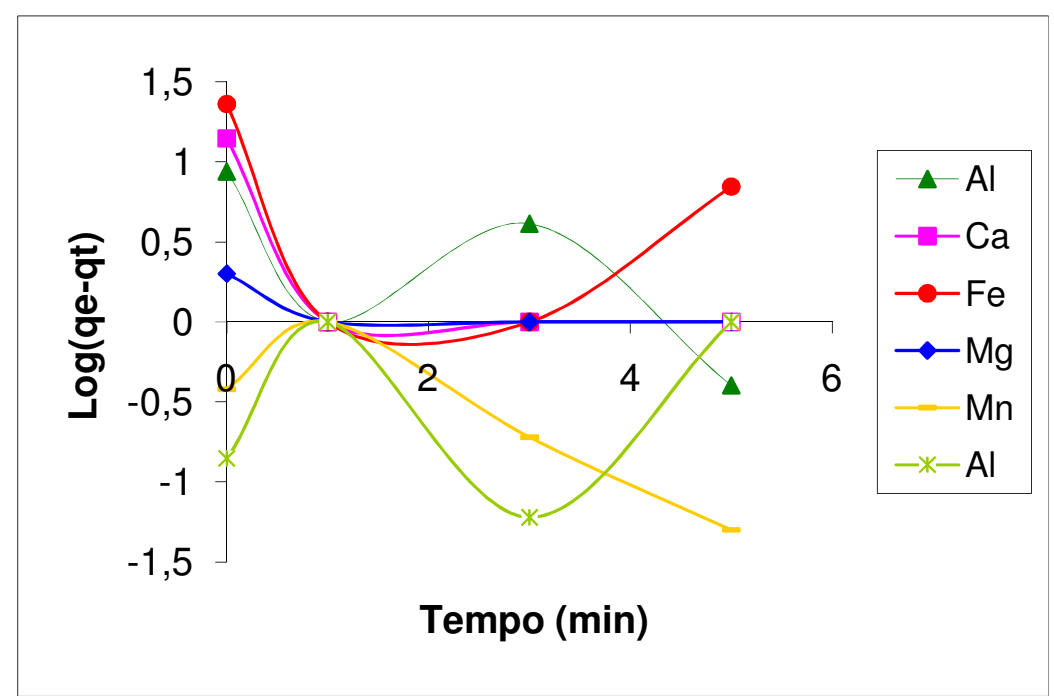

Figura 65 - Modelo de pseudo-primeira ordem aplicado a biossorção.

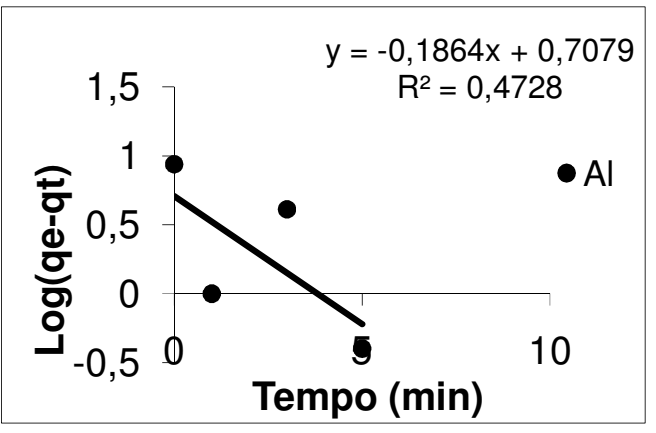

Figura 66 - Modelo de pseudo-primeira ordem para o Al na presença dos co-ions.

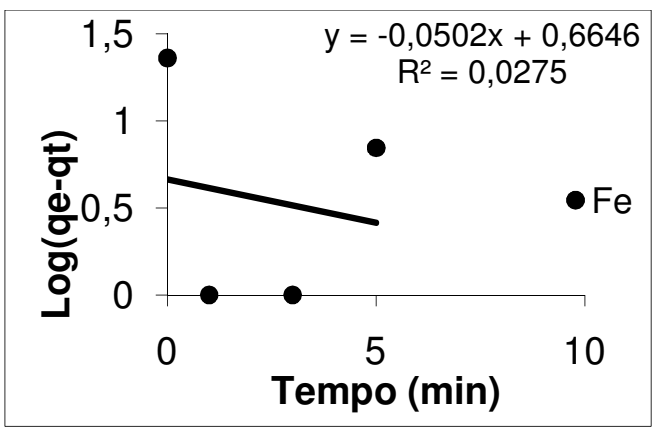

Figura 68 - Modelo de pseudo-primeira ordem para o Fe na presença dos co-ions.

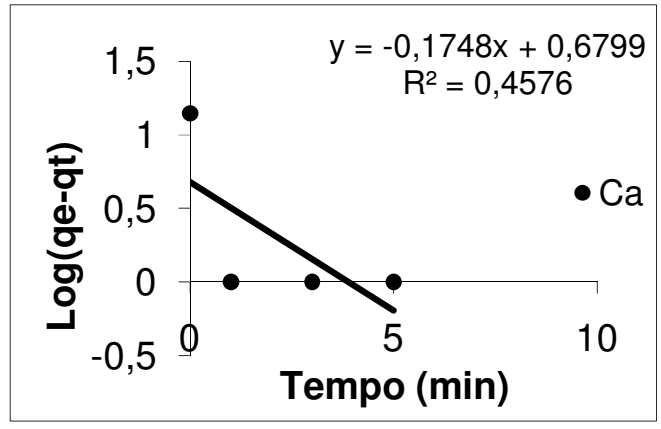

Figura 67 - Modelo de pseudo-primeira ordem para o Ca na presença dos co-ions.

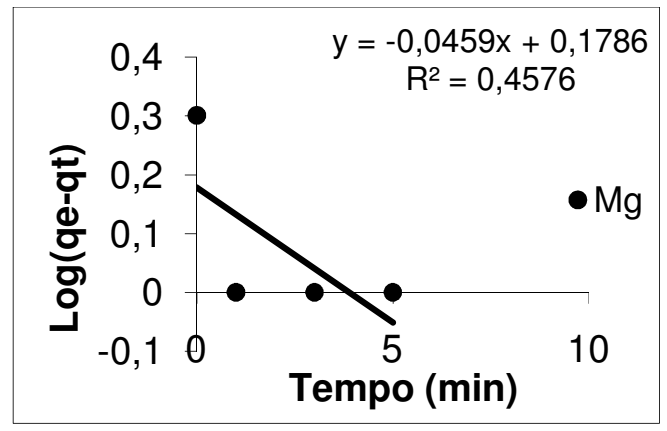

Figura 69 - Modelo de pseudo-primeira ordem para o Mg na presença dos co-ions. 


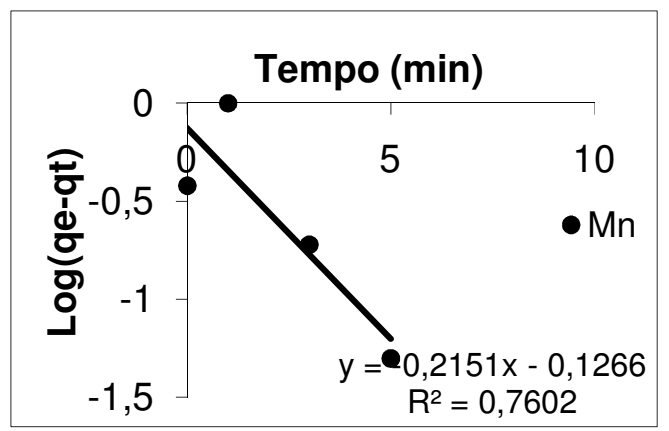

Figura 70 - Modelo de pseudo-primeira ordem para o $\mathrm{Mn}$ na presença dos co-ions.

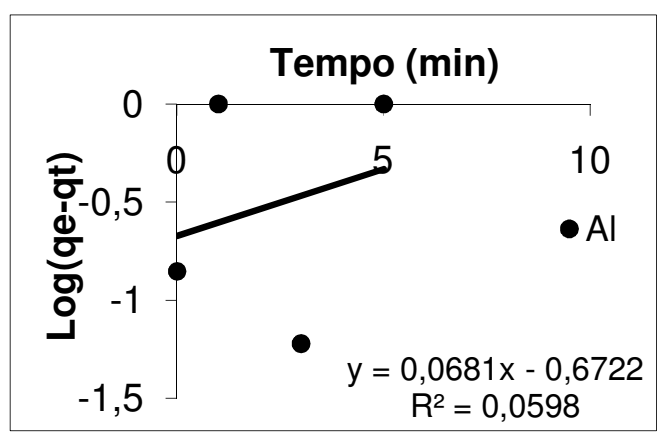

Figura 71 - Modelo de pseudo-primeira ordem para o Zn na presença dos co-ions.

Como pode ser visualizado, o modelo cinético de pseudo-primeira ordem baseado na capacidade do sólido não se ajustou aos dados experimentais, tanto para o todo como para nenhum dos oito metais estudados em sistema multielementar (Figuras 66, 67, 68, 69, 70 e 71).

Entretanto, quando analisados os dados experimentais segundo o modelo cinético de pseudo-segunda ordem (Figura 72), o coeficiente de correlação $\left(R^{2}\right)$ para o Ca, Fe e Mg e também para a somatória dos metais é maior que 0,9 (Figuras 74, $75,77$ e 79$)$.

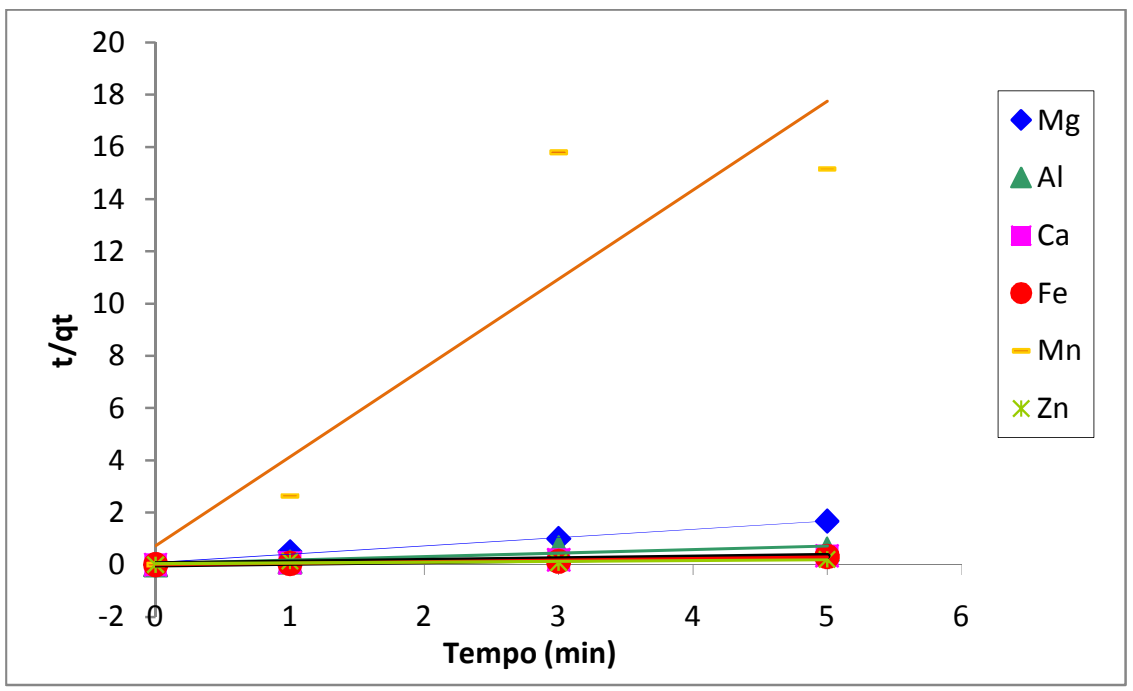

Figura 72 - Modelo de pseudo-segunda ordem aplicado a biossorção: Metais 


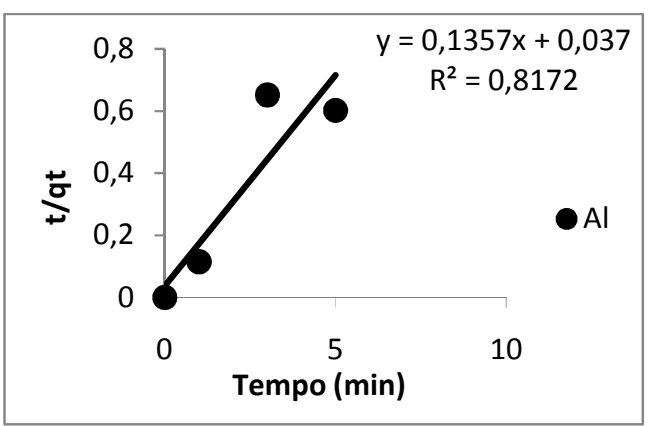

Figura 73 - Modelo de pseudo-segunda ordem para o Al na presença dos co-ions.

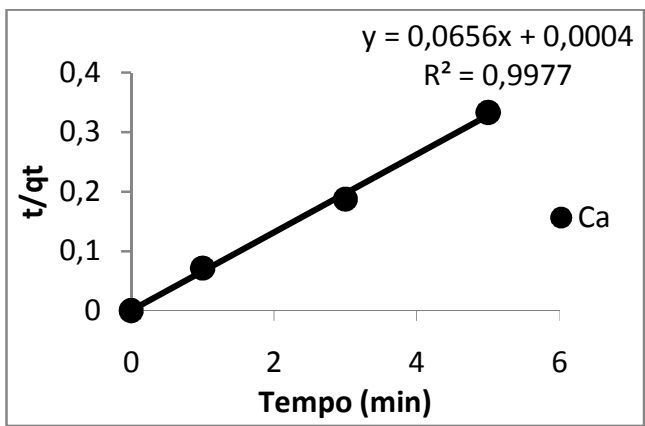

Figura 75 - Modelo de pseudo-segunda ordem para o Ca na presença dos co-ions.

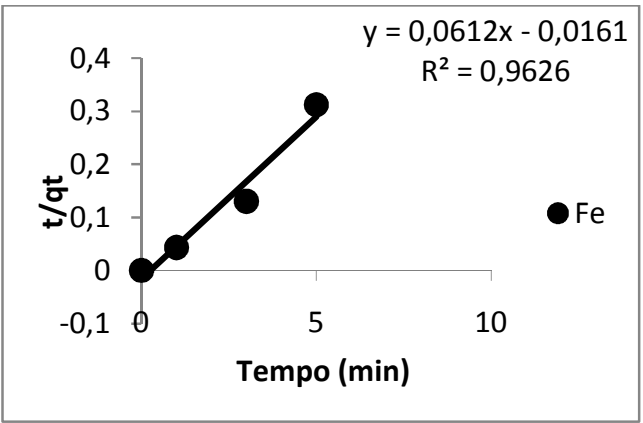

Figura 77 - Modelo de pseudo-segunda ordem para o Fe na presença dos co-ions.

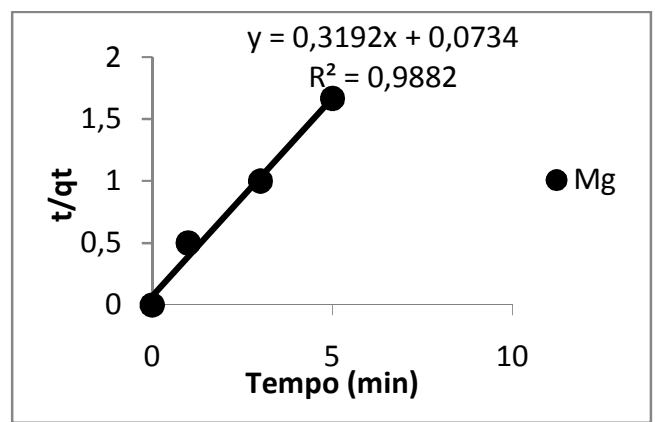

Figura 74 - Modelo de pseudo-segunda ordem para o Mg na presença dos co-ions.

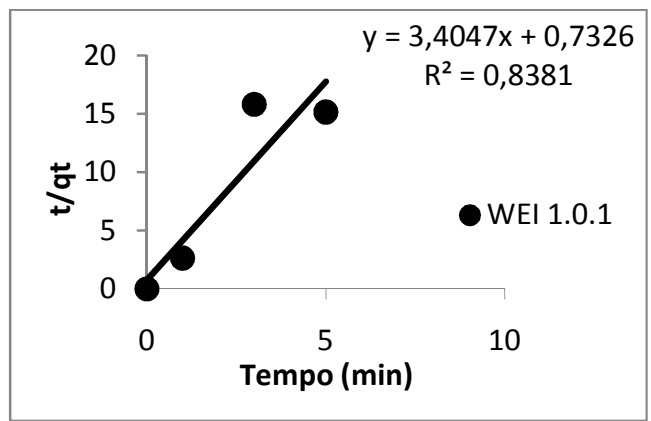

Figura 76 - Modelo de pseudo-segunda ordem para o $\mathrm{Mn}$ na presença dos co-ions

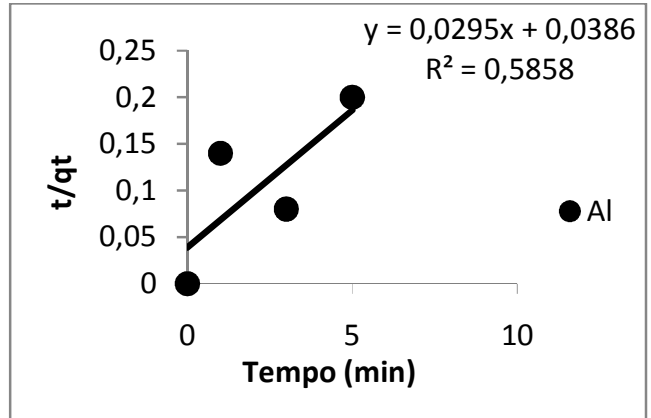

Figura 78 - Modelo de pseudo-segunda ordem para o Zn na presença dos co-ions. 


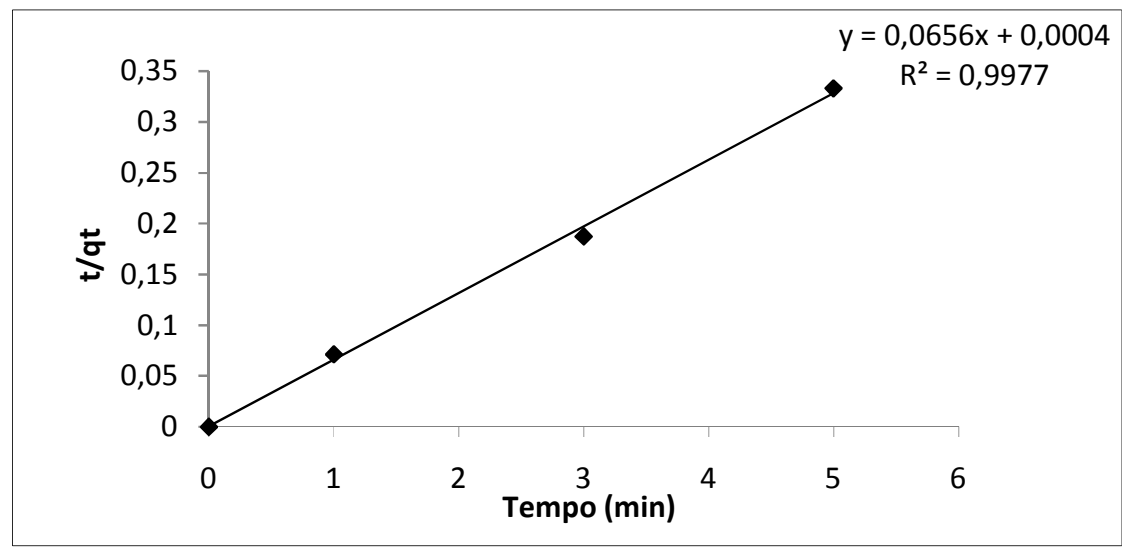

Figura 79 - Modelo de pseudo-segunda ordem aplicado a biossorção: Total.

Os valores dos parâmetros obtidos através do modelo de pseudo-segunda ordem foram calculados e encontram-se na Tabela 16.

Em destaque os resultados que obtiveram coeficiente de correlação maior que 0,9 .

Tabela 16 - Parâmetros cinéticos para a biossorção dos metais presentes na DAM por Rhodococcus opacus.

\begin{tabular}{cc|cccc}
\hline & Exp. & \multicolumn{4}{c}{ Cin. de Pseudo-Segunda Ordem } \\
& $\begin{array}{c}\mathrm{q}_{\mathrm{exp}} \\
\left(\mathrm{mgg}^{-1}\right)\end{array}$ & $\begin{array}{c}\mathrm{q}_{\mathrm{e}} \\
\left(\mathrm{mgg}^{-1}\right)\end{array}$ & $\begin{array}{c}\mathrm{k} \\
\left(\mathrm{mgg}^{-1} \mathrm{~min}^{-1}\right)\end{array}$ & $\begin{array}{c}\mathrm{V}_{0} \\
\left(\mathrm{~g}^{-1} \mathrm{mgmin}^{-1}\right)\end{array}$ & $\mathrm{R}^{2}$ \\
\cline { 2 - 6 } Total & 48,33 & 43,29 & 0,281 & 526,316 & 0,9970 \\
$\mathbf{A l}$ & 8,7 & 7,369 & 0,498 & 27,027 & 0,8172 \\
$\mathbf{C a}$ & 14 & 15,244 & 10,758 & 2500 & 0,9977 \\
$\mathbf{C u}$ & 0,43 & 0,232 & 10,776 & 0,58 & 0,3086 \\
$\mathbf{F e}$ & 23 & 16,34 & 0,023 & 6,211 & 0,9626 \\
$\mathbf{M g}$ & 2 & 3,133 & 1,388 & 13,624 & 0,9882 \\
$\mathbf{M n}$ & 0,38 & 0,294 & 15,792 & 1,365 & 0,8381 \\
$\mathbf{N i}$ & 1,05 & 1,302 & 0,07 & 0,118 & 0,1294 \\
$\mathbf{Z n}$ & 0,14 & 0,168 & 8,858 & 0,25 & 0,6029 \\
\hline
\end{tabular}

Apesar de o coeficiente de correlação ser maior que 0,9 para o $\mathrm{Ca}, \mathrm{Fe}, \mathrm{Mg}$ e também para a somatória dos metais, quando compara-se a quantidade de metal capitado experimentalmente $\left(q_{\text {exp }}\right)$ com a calculada utilizando-se os modelos cinéticos propostos pela literatura $\left(q_{\mathrm{e}}\right)$, as mesmas não conferem. 
Confrontando os resultados supracitados (Tabela 16) com os encontrados por outros pesquisadores (Tabelas 17 e 18), verifica-se que assim como neste trabalho, na maioria dos casos os processos biossortivos seguem mecanismo cinético de pseudo-segunda ordem, sempre com coeficientes de correlação maior ou igual a 0,99 e, às vezes, também com diferença entre a quantidade de metal captado experimentalmente e calculado segundo o modelo proposto.

Tabela 17 - Parâmetros cinéticos encontrados na literatura: modelo cinético de pseudoprimeira ordem.

\begin{tabular}{|c|c|c|c|c|c|c|}
\hline & \multirow[b]{2}{*}{ Biomassa } & \multirow{2}{*}{$\begin{array}{l}\text { Exp. } \\
q_{\text {exp }} \\
\left(\mathrm{mgg}^{-1}\right)\end{array}$} & \multicolumn{3}{|c|}{$\begin{array}{c}\text { Cinética de Pseudo-Primeira } \\
\text { Ordem }\end{array}$} & \multirow[b]{2}{*}{ Referência } \\
\hline & & & $\begin{array}{c}\mathrm{q}_{\mathrm{e}} \\
\left(\mathrm{mgg}^{-1}\right)\end{array}$ & $\begin{array}{c}\mathrm{k} \\
\left(\min ^{-1}\right)\end{array}$ & $\mathrm{R}^{2}$ & \\
\hline Al & Rhodococcus opacus & - & - & 1,175 & 0,99 & $\begin{array}{l}\text { Cayllahua, Carvalho \& } \\
\text { Torem, } 2009\end{array}$ \\
\hline Al & Padina pavonica & 1,96 & 1,48 & 0,048 & 0,97 & Sari \& Tuzen, 2009 \\
\hline $\mathrm{Cu}$ & Rhodococcus opacus & 21,4 & 3,73 & $2,9.10^{-2}$ & 0,89 & Bueno, 2007 \\
\hline $\mathrm{Ni}$ & Cystoseria indica & 42 & 39,914 & 0,044 & 0,97 & $\begin{array}{l}\text { Pahlavanzadeh et al., } \\
2010\end{array}$ \\
\hline $\mathrm{Ni}$ & Nizmuddina zanardini & 41 & 39,264 & 0,039 & 0,99 & $\begin{array}{l}\text { Pahlavanzadeh et al., } \\
2010\end{array}$ \\
\hline $\mathrm{Ni}$ & Sargassum glaucescens & 42 & 35,645 & 0,041 & 0,98 & $\begin{array}{c}\text { Pahlavanzadeh et al., } \\
2010\end{array}$ \\
\hline $\mathrm{Ni}$ & Padina australis & 21 & 17,338 & 0,032 & 0,98 & $\begin{array}{l}\text { Pahlavanzadeh et al., } \\
2010\end{array}$ \\
\hline $\mathrm{Zn}$ & Rhodococcus opacus & - & 0,21 & $3,7.10^{-2}$ & 0,66 & Vásquez, 2005 \\
\hline
\end{tabular}

Tabela 18 - Parâmetros cinéticos encontrados na literatura: modelo cinético de pseudosegunda ordem.

\begin{tabular}{|c|c|c|c|c|c|c|c|}
\hline & \multirow{2}{*}{ Biomassa } & \multirow{2}{*}{$\begin{array}{c}\text { Exp. } \\
q_{\text {exp }} \\
\left(\mathrm{mgg}^{-1}\right)\end{array}$} & \multicolumn{4}{|c|}{ Cinética de Pseudo-Segunda Ordem } & \multirow[b]{2}{*}{ Referência } \\
\hline & & & $\begin{array}{c}\mathrm{q}_{\mathrm{e}} \\
\left(\mathrm{mgg}^{-1}\right)\end{array}$ & $\begin{array}{c}\mathrm{k} \\
\left(\mathrm{gmg}^{-1} \mathrm{~min}^{-1}\right)\end{array}$ & $\begin{array}{c}\mathrm{V}_{0} \\
\left(\mathrm{mgg}^{-1} \mathrm{~min}^{-1}\right)\end{array}$ & $\mathrm{R}^{2}$ & \\
\hline Al & Rhodococcus opacus & - & - & 1,8288 & - & 0,99 & $\begin{array}{c}\text { Cayllahua, } \\
\text { Carvalho \& } \\
\text { Torem, } 2009\end{array}$ \\
\hline Al & Padina pavonica & 1,96 & 1,96 & 0,108 & - & 0,99 & $\begin{array}{c}\text { Sari \& Tuzen, } \\
2009\end{array}$ \\
\hline $\mathrm{Cu}$ & Rhodococcus opacus & 21,4 & 19,1 & 0,67 & 243,9 & 0,99 & Bueno, 2007 \\
\hline $\mathrm{Ni}$ & Cystoseria indica & 42 & 47,62 & 0,002 & - & 0,99 & $\begin{array}{l}\text { Pahlavanzadeh } \\
\text { et al., } 2010\end{array}$ \\
\hline $\mathbf{N i}$ & Nizmuddina zanardini & 41 & 45,46 & 0,001 & - & 0,99 & $\begin{array}{l}\text { Pahlavanzadeh } \\
\text { et al., } 2010\end{array}$ \\
\hline $\mathbf{N i}$ & Sargassum glaucescens & 42 & 47,62 & 0,002 & - & 0,99 & $\begin{array}{l}\text { Pahlavanzadeh } \\
\text { et al., } 2010\end{array}$ \\
\hline $\mathrm{Ni}$ & Padina australis & 21 & 23,26 & 0,003 & - & 0,99 & $\begin{array}{l}\text { Pahlavanzadeh } \\
\text { et al., } 2010\end{array}$ \\
\hline $\mathrm{Zn}$ & Rhodococcus opacus & - & 0,21 & 3,37 & 4,856 & 0,99 & Vásquez, 2005 \\
\hline
\end{tabular}




\subsubsection{Isotermas de Adsorção}

Com o intuito de avaliar a capacidade de captação do biossorvente e também de compreender os mecanismos de ligação, a afinidade da biomassa com os metais e como ambos são afetados por variações no processo biossortivo, foram construídas isotermas de sorção aplicando-se os modelos de Freundlich (Equação 12) e de Langmuir (Equação 13) (FEBRIANTO et al., 2009.).

$$
\begin{aligned}
\ln q & =\ln K+\left(\frac{1}{n}\right) \ln C_{e} \\
\frac{C_{e}}{q_{e}} & =\frac{1}{b q_{\max }}+\frac{C_{e}}{q_{\max }}
\end{aligned}
$$

Onde:

q - quantidade de íons metálicos captados

$\mathrm{K}$ - constante relacionada com a capacidade de adsorção

$\mathrm{n}$ - constante relacionada com a intensidade do sitio ou grau de favorecimento da adsorção

$\mathrm{C}_{\mathrm{e}}$ - concentração no equilíbrio

$\mathrm{q}_{\mathrm{e}}$ - quantidade de íons metálicos captados no equilíbrio

$\mathrm{q}_{\max }$ - quantidade máxima de íons metálicos captados

Os resultados obtidos encontram-se nas Figuras 80,81, 82, 83, 84, 85 e 86, e nas Figuras 87, 88, 89, 90, 91, 92 e 93, para Langmuir e Freundlich, respectivamente. 


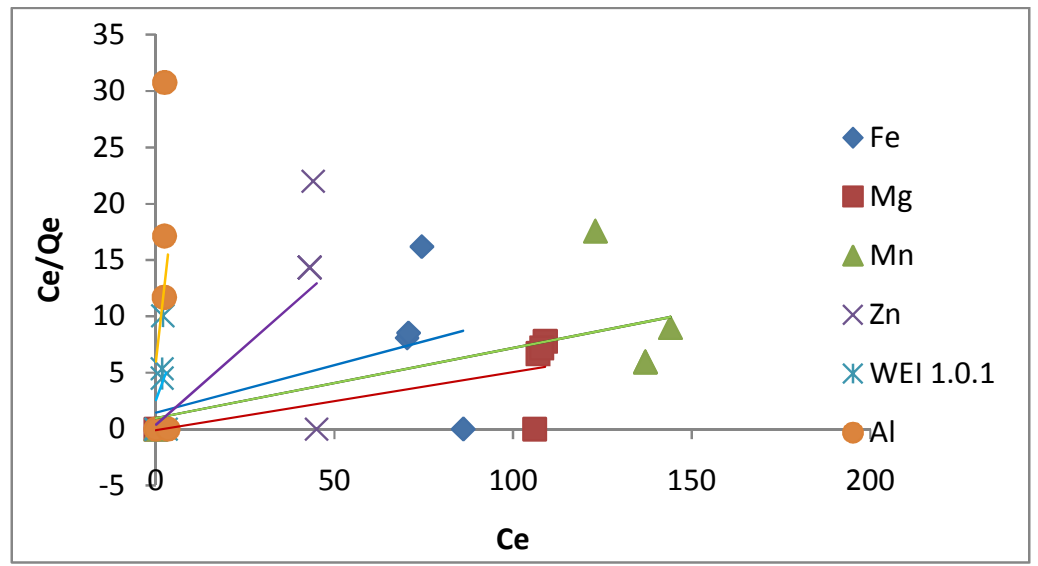

Figura 80 - Equação de Langmuir para sistemas monoelementares para biossorção.

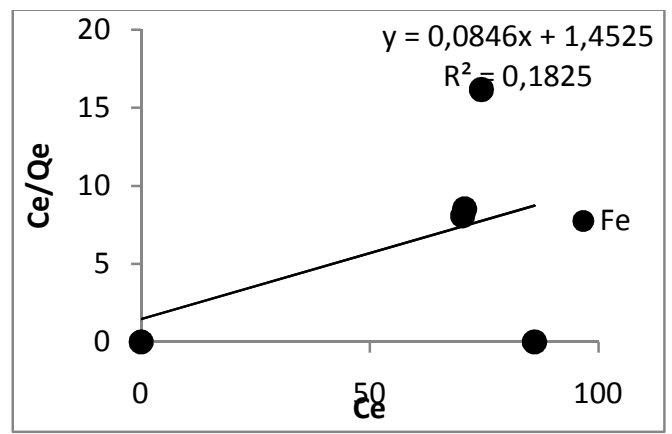

Figura 81 - Equação de Langmuir para sistemas monoelementares para biossorção do Al na presença de co-ions.

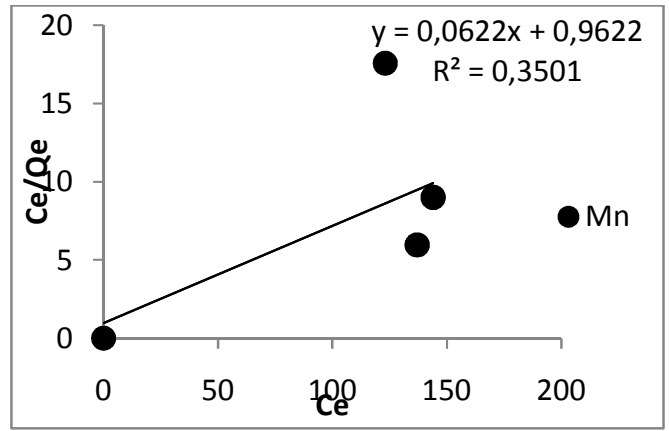

Figura 83 - Equação de Langmuir para sistemas monoelementares para biossorção do Fe na presença de co-ions.

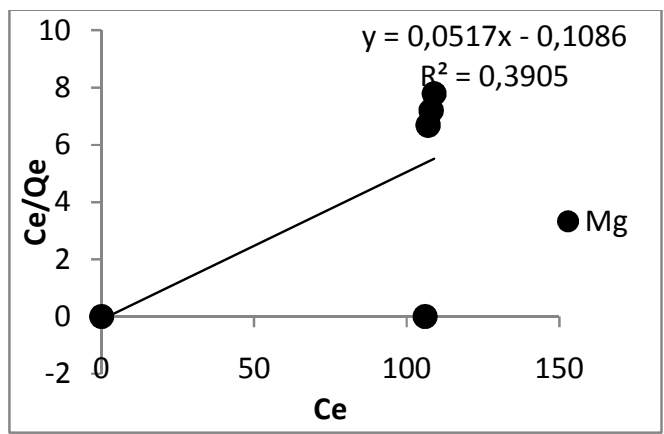

Figura 82 - Equação de Langmuir para sistemas monoelementares para biossorção do Ca na presença de co-ions.

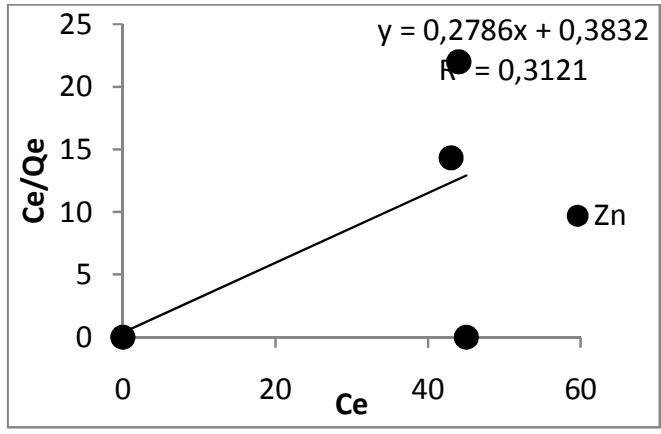

Figura 84 - Equação de Langmuir para sistemas monoelementares para biossorção do Mg na presença de co-ions. 


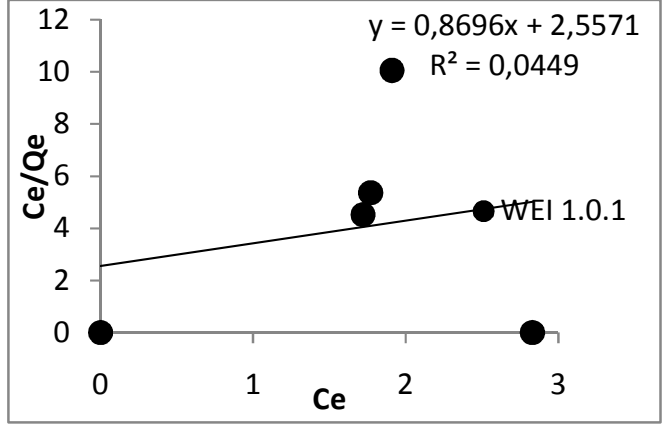

Figura 85 - Equação de Langmuir para sistemas monoelementares para biossorção do $\mathrm{Mn}$ na presença de co-ions.

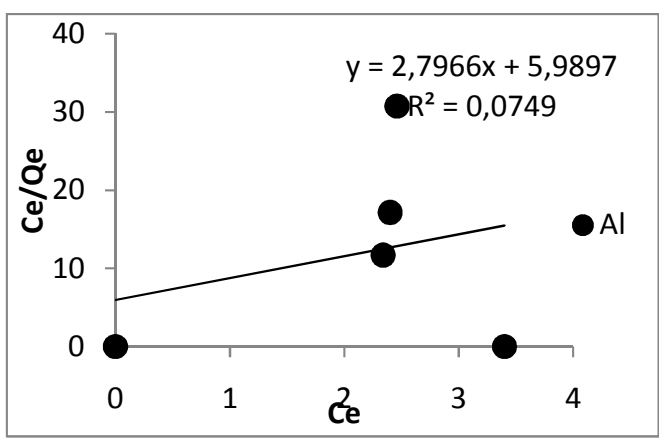

Figura 86 - Equação de Langmuir para sistemas monoelementares para biossorção do $\mathrm{Zn}$ na presença de co-ions.

Como pode ser visualizado, o modelo de Langmuir para sistemas monoelementares não se ajustou aos dados experimentais para nenhum dos oito metais estudados em sistema multielementar, já que os coeficientes de correlação $\left(R^{2}\right)$ variam de 0,04 a 0,39.

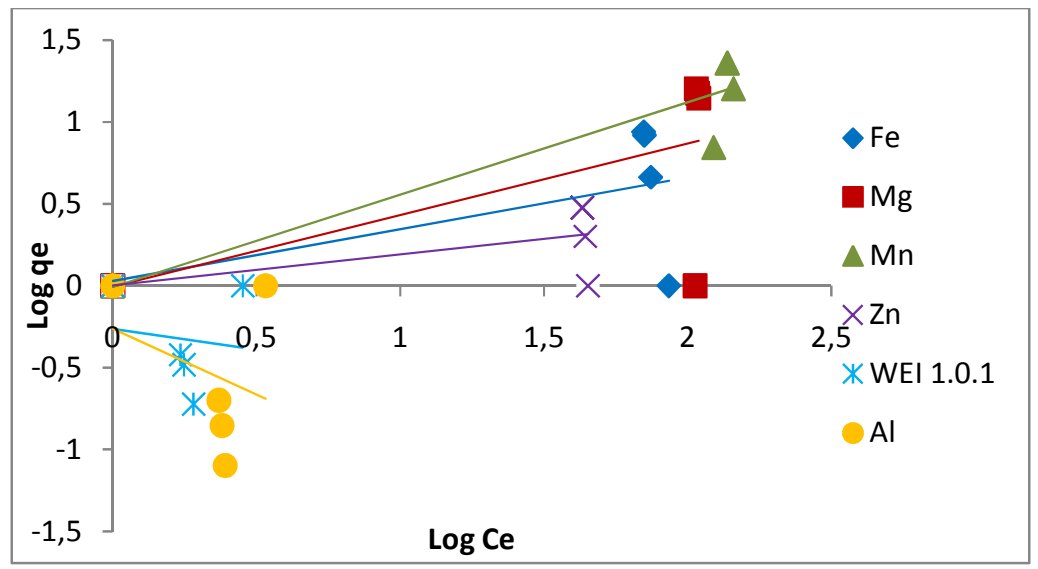

Figura 87 - Equação de Freundlich para sistemas monoelementares para biossorção.

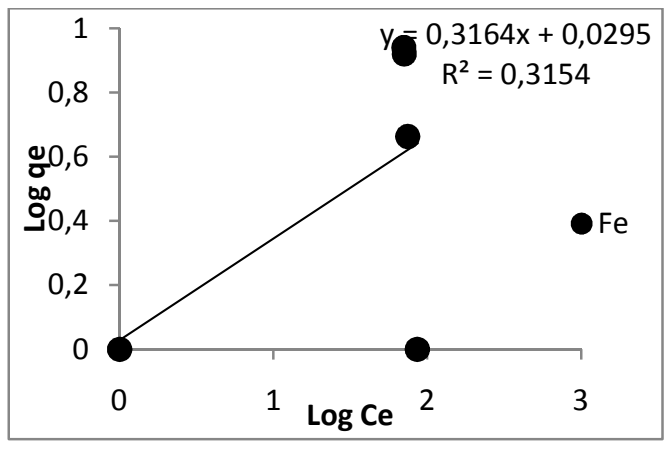

Figura 88 - Equação de Freundlich para sistemas monoelementares para biossorção do Al na presença de co-ions.

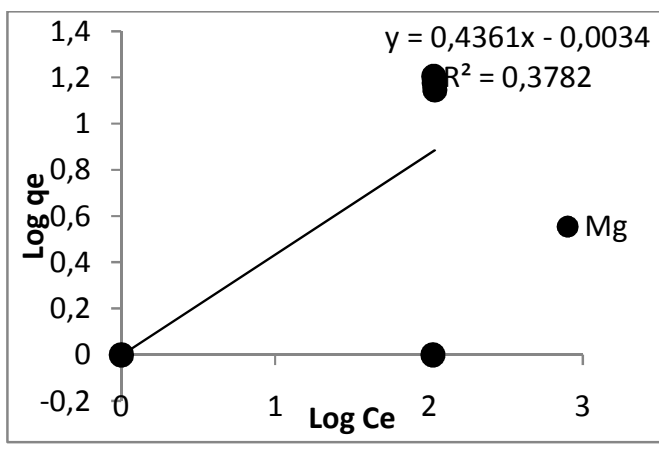

Figura 89 - Equação de Freundlich para sistemas monoelementares para biossorção do Ca na presença de co-ions. 


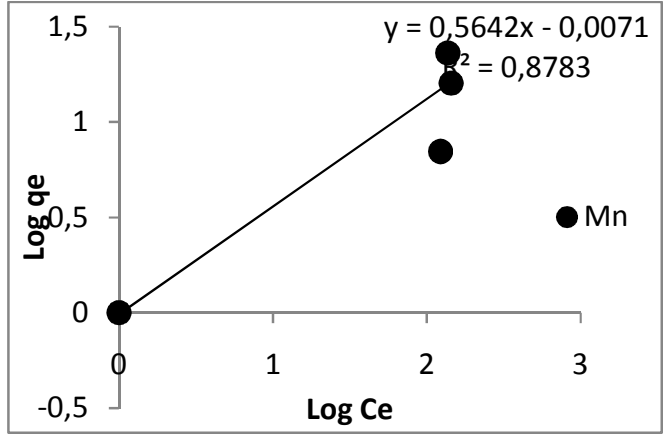

Figura 90 - Equação de Freundlich para sistemas monoelementares para biossorção do Fe na presença de co-ions.

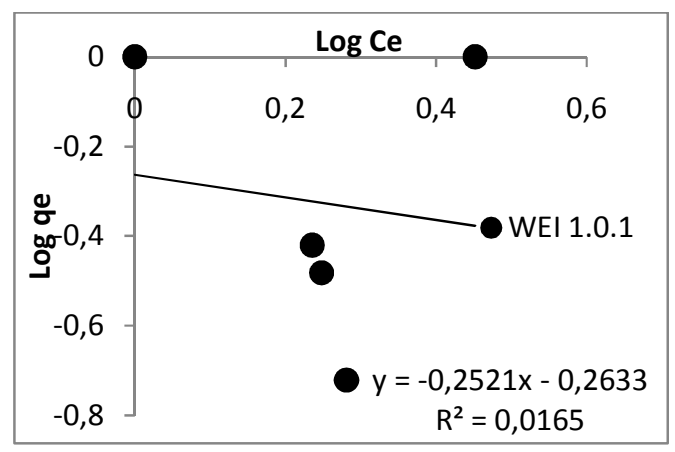

Figura 92 - Equação de Freundlich para sistemas monoelementares para biossorção do Mn na presença de co-ions.

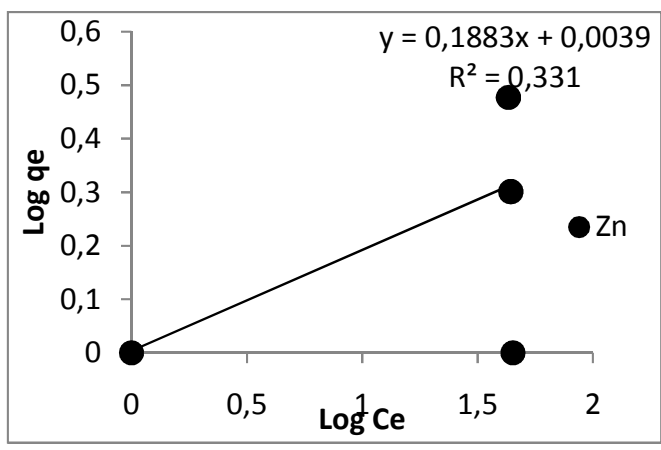

Figura 91 - Equação de Freundlich para sistemas monoelementares para biossorção do $\mathrm{Mg}$ na presença de co-ions.

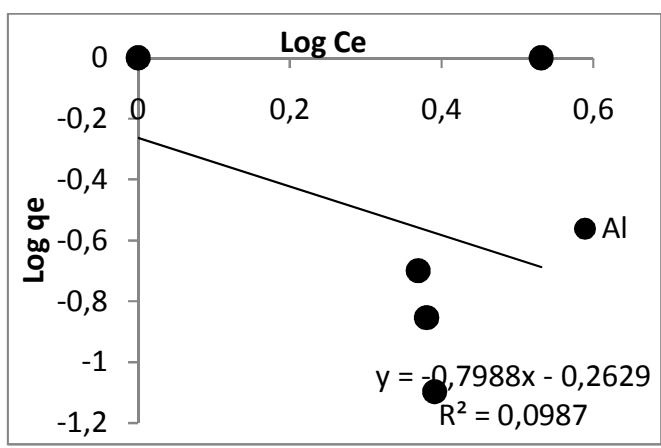

Figura 93 - Equação de Freundlich para sistemas monoelementares para biossorção do $\mathrm{Zn}$ na presença de co-ions.

O modelo de Freundlich para sistemas monoelementares, também não se ajustou aos dados experimentais para nenhum dos oito metais estudados em sistema multielementar. Os coeficentes de correlação $\left(R^{2}\right)$ obtidos nas linearizações variam de 0,01 a 0,87.

$\mathrm{Na}$ Tabela 19, encontram-se as constantes de adsorção para os modelos de Langmuir e Freundlich encontradas na literatura. 
Tabela 19 - Constantes de adsorção para os modelos de Langmuir e Freundlich encontradas na literatura.

\begin{tabular}{|c|c|c|c|c|c|c|c|c|}
\hline & \multirow[b]{2}{*}{ Biomassa } & \multicolumn{3}{|c|}{ Langmuir } & \multicolumn{3}{|c|}{ Freundlich } & \multirow[b]{2}{*}{ Referência } \\
\hline & & $\begin{array}{c}\mathrm{q}_{\max } \\
\left(\mathrm{mgg}^{-1}\right)\end{array}$ & $\begin{array}{c}\mathrm{b} \\
\left(\mathrm{Lmg}^{-1}\right)\end{array}$ & $\mathrm{R}^{2}$ & $\begin{array}{c}\mathrm{K} \\
\left(\mathrm{Lg}^{-1}\right)\end{array}$ & $1 / n$ & $\mathrm{R}^{2}$ & \\
\hline Al & $\begin{array}{c}\text { Rhodococcus } \\
\text { opacus }\end{array}$ & 41,59 & 0,9611 & 0,9948 & 19,16 & 2,677 & 0,9651 & $\begin{array}{c}\text { Cayllahua, } \\
\text { Carvalho \& Torem, } \\
2009\end{array}$ \\
\hline $\mathrm{Cu}$ & $\begin{array}{c}\text { Rhodococcus } \\
\text { opacus }\end{array}$ & 32,15 & 0,0589 & 0,986 & 5,33 & 2,91 & 0,969 & Bueno, 2007 \\
\hline $\mathrm{Cu}$ & $\begin{array}{c}\text { Geobacillus } \\
\text { thermodenitrificans }\end{array}$ & 50,0 & 0,87 & 0,964 & - & 3,88 & 0,957 & $\begin{array}{c}\text { Chaterrjee, } \\
\text { Bhattacharjee \& } \\
\text { Chandra, 2010 }\end{array}$ \\
\hline $\mathrm{Cu}$ & Farelo de arroz & 33,58 & 0,2350 & 0,9455 & 7,130 & 0,4053 & 0,8539 & Wang \& Qin, 2004 \\
\hline $\mathrm{Fe}$ & $\begin{array}{c}\text { Geobacillus } \\
\text { thermodenitrificans }\end{array}$ & 79,9 & 5,58 & 0,524 & 31,3 & 0,327 & 0,339 & $\begin{array}{c}\text { Chaterrjee, } \\
\text { Bhattacharjee \& } \\
\text { Chandra, } 2010\end{array}$ \\
\hline $\mathrm{Fe}$ & $\begin{array}{l}\text { Streptomyces } \\
\text { rimosus }\end{array}$ & 125 & 0,0952 & 0,99 & 27,76 & 0,2694 & 0,8346 & Selatnia et al., 2004 \\
\hline Mn & Rhizobium etli & 62,4 & 0,1 & 0,993 & 42,7 & 0,11 & 0,998 & $\begin{array}{c}\text { Pulsawat et al., } \\
2003\end{array}$ \\
\hline $\mathrm{Ni}$ & $\begin{array}{l}\text { Pseudomonas } \\
\text { aeruginosa }\end{array}$ & 113,6 & 0,22 & 0,97 & 24,14 & 1,64 & 0,99 & $\begin{array}{c}\text { Gabr, Hassan \& } \\
\text { Shoreit, } 2008\end{array}$ \\
\hline $\mathbf{N i}$ & Cystoseria indica & 47,619 & 0,035 & 0,997 & 3,126 & 0,522 & 0,957 & $\begin{array}{c}\text { Pahlavanzadeh et } \\
\text { al., } 2010\end{array}$ \\
\hline $\mathrm{Ni}$ & $\begin{array}{l}\text { Nizmuddina } \\
\text { zanardini }\end{array}$ & 52,632 & 0,028 & 0,998 & 2,624 & 0,577 & 0,971 & $\begin{array}{c}\text { Pahlavanzadeh et } \\
\text { al., } 2010\end{array}$ \\
\hline $\mathrm{Ni}$ & $\begin{array}{l}\text { Sargassum } \\
\text { glaucescens }\end{array}$ & 55,556 & 0,026 & 0,996 & 2,735 & 0,569 & 0,964 & $\begin{array}{l}\text { Pahlavanzadeh et } \\
\text { al., } 2010\end{array}$ \\
\hline $\mathbf{N i}$ & Padina australis & 26,316 & 0,025 & 0,999 & 1,432 & 0,548 & 0,96 & $\begin{array}{c}\text { Pahlavanzadeh et } \\
\text { al., } 2010\end{array}$ \\
\hline $\mathrm{Zn}$ & Grânulos aeróbios & 48,309 & 0,008 & 0,904 & 2,547 & 2,196 & 0,958 & Sun et al., 2008 \\
\hline $\mathrm{Zn}$ & $\begin{array}{c}\text { Geobacillus } \\
\text { thermodenitrificans }\end{array}$ & 48,26 & 2,02 & 0,98 & - & 5,16 & 0,963 & $\begin{array}{c}\text { Chaterrjee, } \\
\text { Bhattacharjee \& } \\
\text { Chandra, } 2010\end{array}$ \\
\hline $\mathrm{Zn}$ & $\begin{array}{c}\text { Rhodococcus } \\
\text { opacus }\end{array}$ & 1,352 & 0,095 & 0,9237 & 0,124 & 1,716 & 0,9402 & Vásquez, 2005 \\
\hline
\end{tabular}

\subsection{Caracterização da biomassa após ensaios biossortivos}

\subsubsection{MEV e EDS}

A fim de se identificar possíveis alterações na estrutura, presença de metais na superfície das células e/ou mudanças na composição da biomassa após os ensaios biossortivos, novas imagens foram obtidas no microscópio eletrônico de varredura (Figuras 94, 95, 96, 97 e 98) e também foram realizadas medidas no EDS (Figuras 100, 101, 102, 103 e 104). 
Durante as análises junto ao MEV foram obtidas imagens com 10 e 35 mil vezes de aumento. Com exceção da amostra que permaneceu 10 minutos em contato com 0 biossorvente, em todas as outras imagens percebeu-se homogeneidade do material. Por este motivo, imagens tanto com aumento de 35 quanto com de 10 mil vezes são apresentadas nas Figuras 97 e 98, respectivamente, para a amostra que permaneceu em contato com a solução de DAM sintética por 10 minutos.

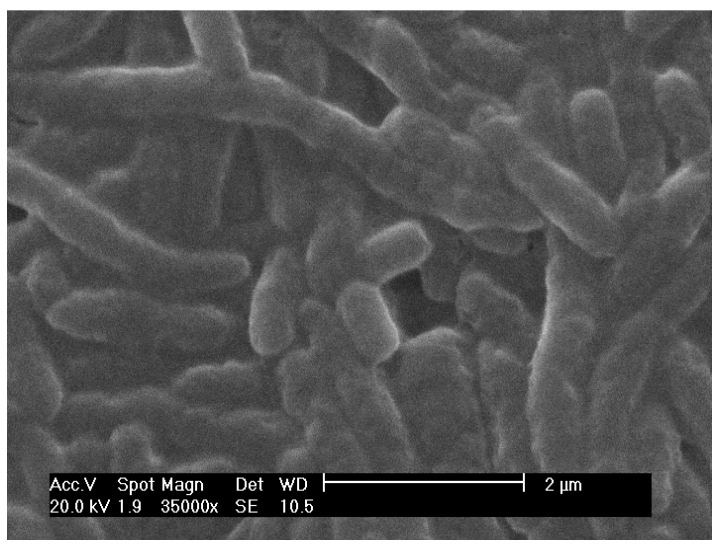

Figura 94 - Imagem de elétrons secundários da biomassa após $1 \mathrm{~min}$.

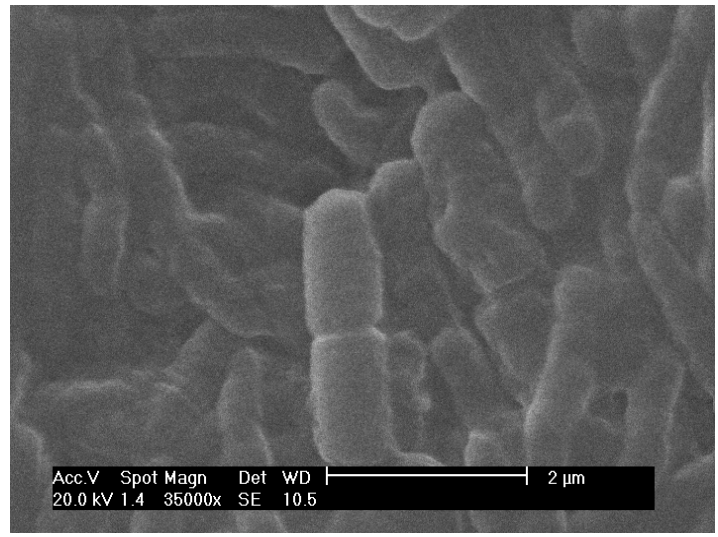

Figura 96 - Imagem de elétrons secundários da biomassa após $5 \mathrm{~min}$.

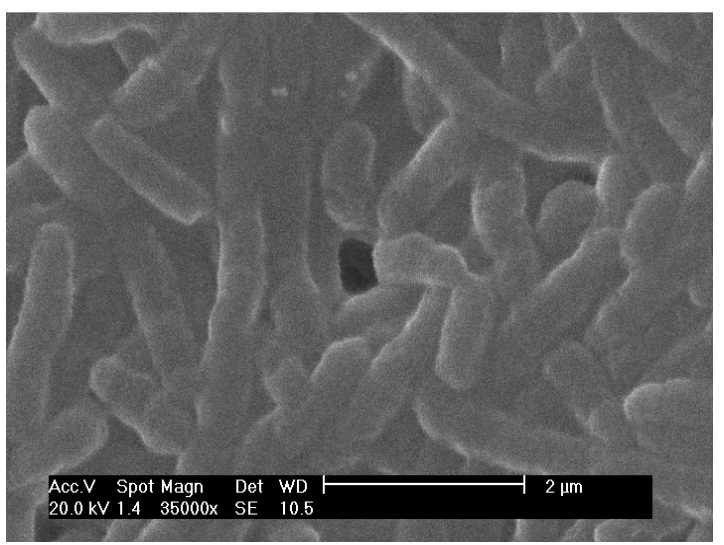

Figura 95 - Imagem de elétrons secundários da biomassa após $3 \mathrm{~min}$.

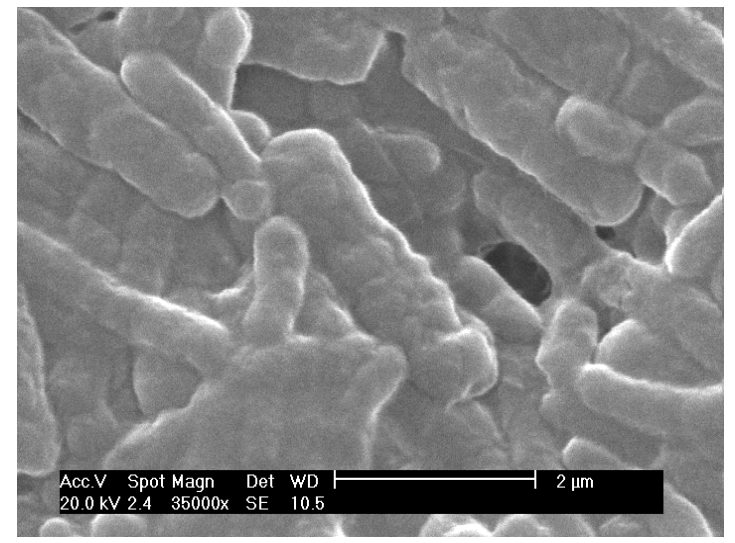

Figura 97 - Imagem de elétrons secundários da biomassa após 10min. 


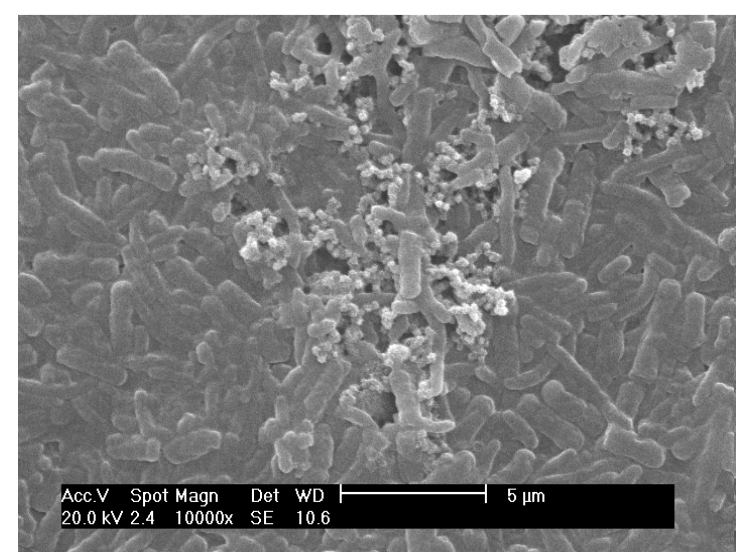

Figura 98 - Imagem de elétrons secundários da biomassa após 10min: lise celular.

Observa-se nas Figuras 94, 95, 96 e 97 que após contato com a DAM ocorreram mudanças na estrutura da biomassa.

Aparentemente, quanto maior o tempo de contato entre a biomassa e a solução metálica, maior o aspecto de "inchaço" nas células bacterianas. Para verificar se a lise da parede celular estava sendo ocasionada pelo $\mathrm{pH}$ da amostra $(2,6)$, analisou-se uma amostra contendo apenas biomassa, água deionizada e ácido sulfúrico (adicionado até $\mathrm{pH}$ 2,6) que permaneceu em contato por 10 minutos.

O resultado do experimento supracitado, que se encontra na Figura 98, evidencia que apesar de ácido $0 \mathrm{pH}$ da solução não é o responsável pelo rompimento da célula. Descarta-se a possibilidade de ter ocorrido turgescência (acumulo excessivo de água por osmose) já que a concentração de metais na solução $(20 \mathrm{mg} / 50 \mathrm{~mL})$ é 20 vezes maior do que a concentração de metais na biomassa ( $\approx 2 \%$ de $50 \mathrm{mg} / 50 \mathrm{~mL}$ - segundo ensaio de perda ao fogo). Supõe-se que os íons metálicos são sorvidos na forma de aquo-complexos (por exemplo, segundo Possa \& dos Santos (2003), em pH menor do que 4 há predominância do aquocomplexo de $\left.\mathrm{Al}-\mathrm{Al}\left(\mathrm{H}_{2} \mathrm{O}\right)_{6}{ }^{3+}\right)$. Assim, a água presente nestes compostos passa então, a permanecer dentro da célula. Talvez, com o decorrer do tempo a estrutura celular não suporte a pressão volumétrica interna e então ocorre o rompimento. 


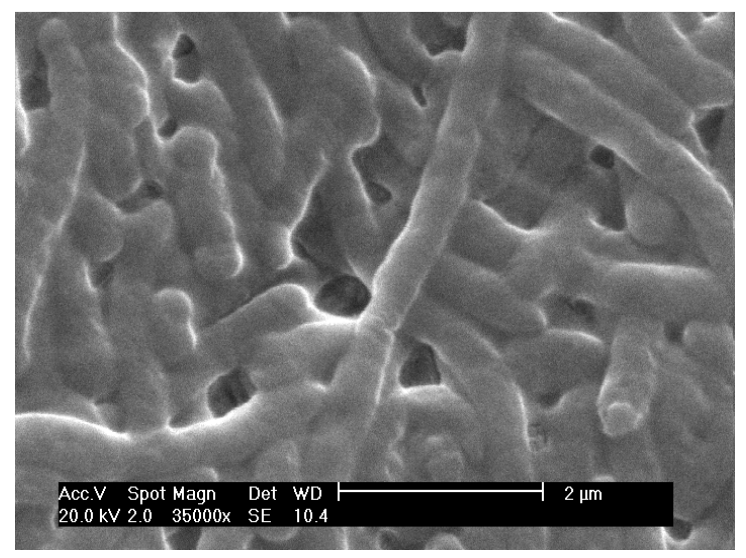

Figura 99 - Imagem de elétrons secundários da biomassa após 10min: solução de $\mathrm{H}_{2} \mathrm{O}+\mathrm{H}_{2} \mathrm{SO}_{4}$ até $\mathrm{pH} 2,6$.

Nas micrografias também não foi possível visualizar claramente se há a presença de novas partículas sobre a superfície celular, com exceção da amostra que permaneceu em contato por 10 minutos (Figura 98). A heterogeneidade desta amostra, como já descrito, parece ter sido causada pelo rompimento da parede celular da Rhodococcus opacus, o que aparentemente permitiu que os componentes celulares se aglomerassem na superfície da biomassa. Por este motivo as análises de EDS nesta amostra foram realizadas tanto em uma região clara quanto em uma área escura, Figuras 103 e 104, respectivamente.

Como esperado, na região clara a concentração de metais supera em 2,5\% vezes mais do que na região escura da mesma amostra. Porém tanto nesta amostra como nas demais (Figuras 100, 101 e 102) a composição da biomassa não se alterou com o incremento do tempo de contato. Porém quando comparadas com a composição da Rhodococcus opacus antes da biossorção, as analises acusam a ausência de $\mathrm{Ca}, \mathrm{K}$ e $\mathrm{Mg}$ e o ganho de $\mathrm{Al}$, antes inexistente na composição bacteriana.

Além da presença de $\mathrm{Al}$, o aumento na porcentagem de $\mathrm{Fe}$ evidencia a captação destes íons metálicos pela biomassa. A ausência de $\mathrm{K}$ pode estar relacionada com a possível troca destes íons com os presentes em solução. Contudo, outros metais como $\mathrm{Ca}, \mathrm{Mg}, \mathrm{Mn}$ e $\mathrm{Zn}$ presentes na solução sintética de DAM não foram identificados nas analises de EDS, muito provavelmente por esta ser uma analise não representativa de todo o material. Além disso, a quantidade total de íons captados pela biomassa não passou de $2,5 \mathrm{mg}$, valor baixo para ser 
detectado através de uma analise semi-quantitativa. Por este mesmo motivo não é possível fechar um balanço de massa.

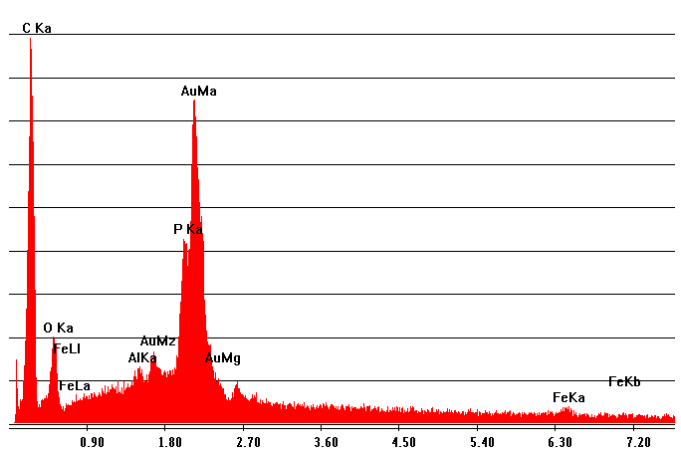

Figura 100 - EDS, biomassa após $1 \mathrm{~min}$.

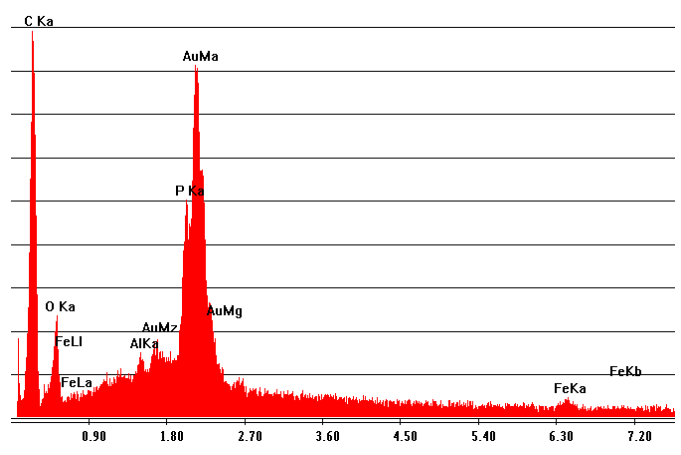

Figura 102 - EDS, biomassa após 5min.

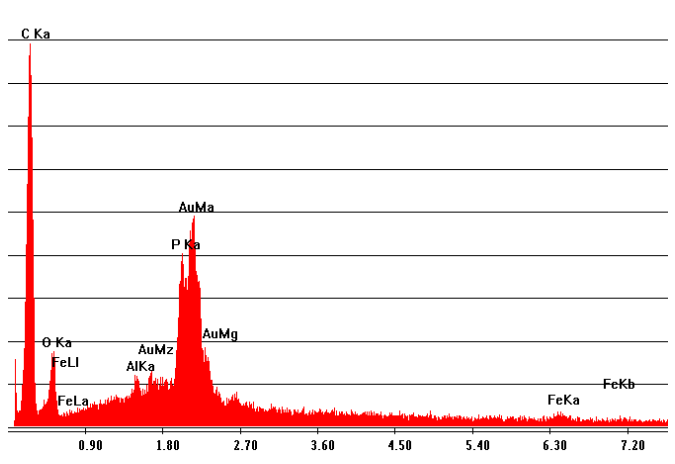

Figura 101 - EDS, biomassa após 3min.

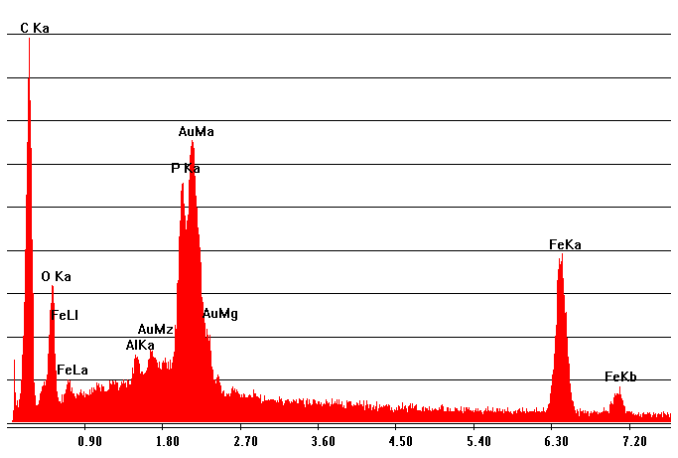

Figura 103 - EDS, biomassa após 10min: região clara

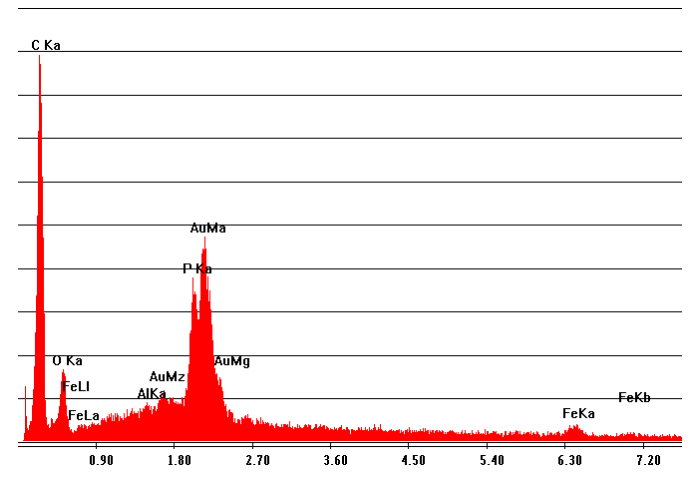

Figura 104 - EDS, biomassa após 10min: região escura. 


\subsubsection{Espectroscopia de Infravermelho}

Com o intuito de se obter informações sobre quais os grupos funcionais estão envolvidos na remoção dos metais e também para entender quais os mecanismos de interação entre os íons metálicos e a biomassa, as amostras provenientes dos processos biossortivos foram submetidas a analises de infravermelho e os espectros comparados com o da biomassa antes do contato com a DAM (Figura 105).

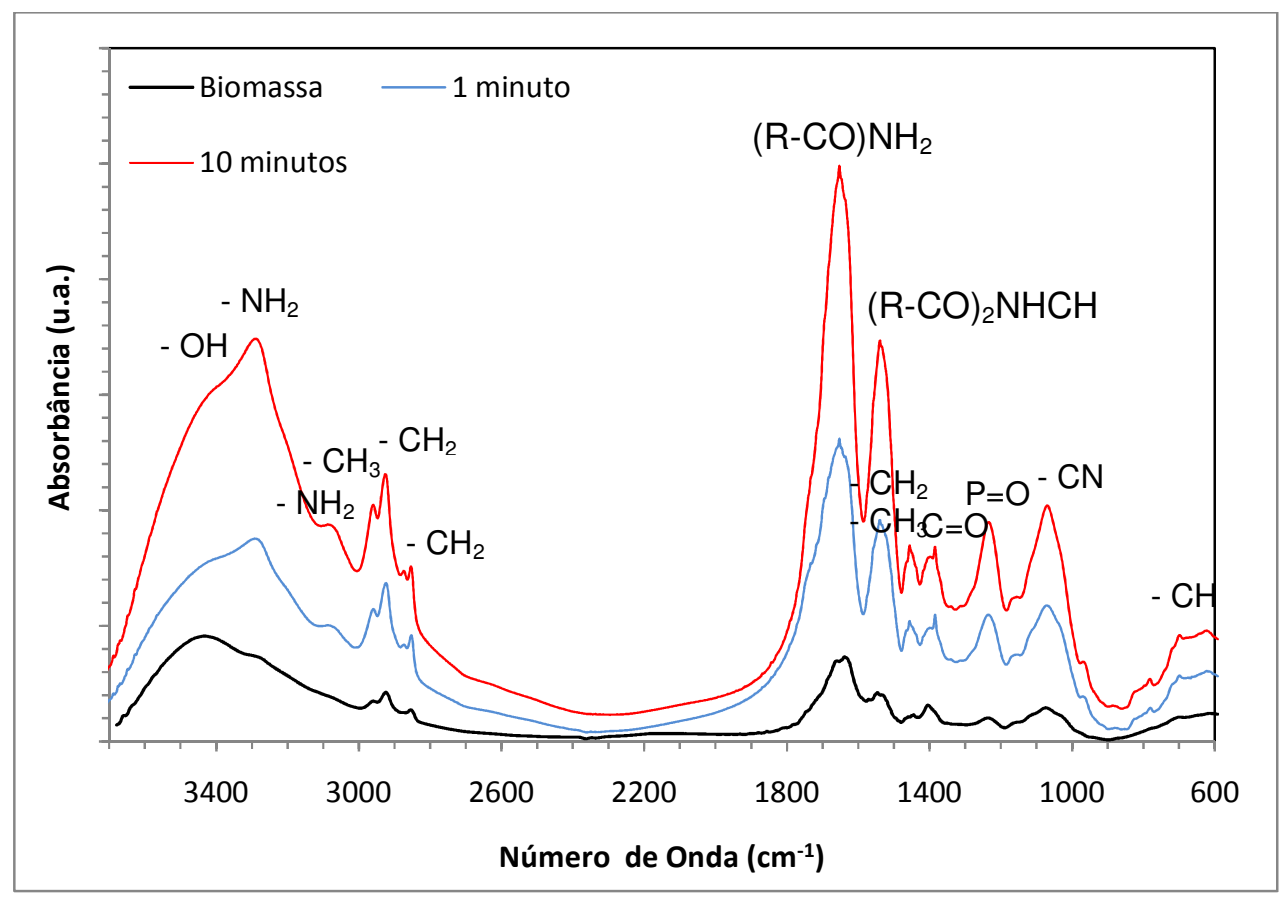

Figura 105 - Espectros da biomassa de Rhodococcus opacus antes e após processo biossortivo.

Quando comparados os espectros de infravermelho obtidos após processo biossortivo com o da biomassa bruta verifica-se que:

1) A banda correspondente aos grupos hidroxílicos $(-\mathrm{OH})$ apresentou um pequeno deslocamento, o que suspeita-se estar relacionado com reações envolvendo os íons metálicos com alcoóis presentes na parede celular ;

2) Houve um incremento da banda correspondente ao $-\mathrm{NH}$ proveniente do estiramento assimétrico do grupo $-\mathrm{NH}_{2}$ e o surgimento de uma nova banda também de $-\mathrm{NH}$ porém proveniente do estiramento simétrico do $-\mathrm{NH}_{2}$. Um 
indicativo de que podem ter ocorrido reações entre as proteínas da superfície celular e os íons metálicos da solução;

3) Há aumento do pico no comprimento de onda de $\approx 2960 \mathrm{~cm}^{-1}\left(-\mathrm{CH}_{3}\right)$ e o surgimento de um novo pico em $\approx 2860 \mathrm{~cm}^{-1}\left(-\mathrm{CH}_{2}\right)$, que podem estar relacionados com reações envolvendo carboidratos;

4) Houve um pequeno deslocamento no pico correspondente ao grupo amida primária $(\mathrm{R}-\mathrm{CO}) \mathrm{NH}_{2}$, pode ser atribuído à interação dos íons metálicos com os átomos de $\mathrm{N}$ e a formação de pontes de hidrogênio, resultado também encontrado por Bueno (2007) para captação de $\mathrm{Pb}$ (II) e Cr (II).

5) Houve incremento do pico correspondente a $\mathrm{P}=\mathrm{O}$ estiramento simétrico do grupo $\mathrm{PO}_{2}{ }^{-}$. Este fato pode estar relacionado com ligações envolvendo os fosfolipídios presentes na parede celular da biomassa.

6) A banda correspondente ao $\mathrm{C}=\mathrm{O}$ também sofreu um pequeno deslocamento, indicando possíveis reações dos íons metálicos com ácidos carboxílicos.

\subsubsection{Potencial Zeta}

A parede celular bacteriana possui cargas elétricas determinadas pela dissociação ou protonação de grupamentos ácidos ou básicos, como os presentes em polissacarídeos, fosfatos e grupos amina (VAN der WAL et al., 1997).

Quando o potencial zeta é nulo, ou seja, quando as cargas opostas se anulam, tem-se o ponto isoelétrico (PIE). Para a Rhodococcus opacus, o PIE encontrado é em pH em torno de 2,6 (Figura 106). 


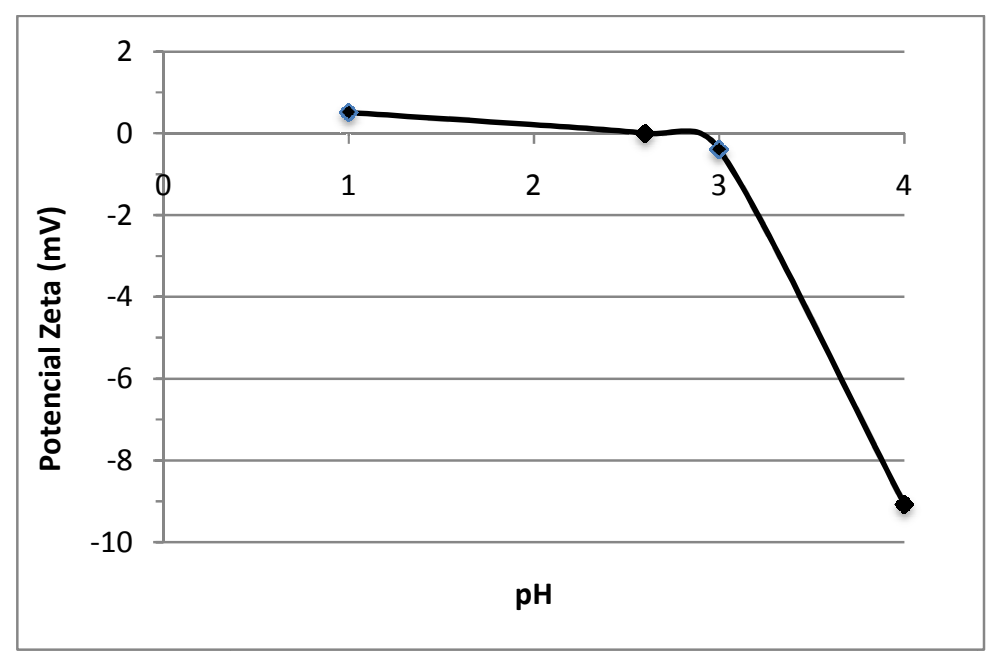

Figura 106 - Potencial Zeta das células Rhodococcus opacus após crescimento em meio YMA

O resultado obtido esta de acordo com a literatura: Vásquez et al. (2007) encontraram pH 2,5; Botero, Torem \& Mesquita (2008) alcançaram pH3,2; Bueno (2007) concluiu que o PIE da Rhodococcus opacus é em pH 2,8.

Quando os valores do PIE ficam entre $\mathrm{pH} 2$ e 2,8, o caráter da carga superficial é dado predominantemente pela presença de ácidos glicurônicos ou outros polissacarídeos com grupos carboxílicos associados (RIJNAARTS et al., 1995 apud BOTERO, TOREM \& MESQUITA, 2008).

Uma carga superficial pode surgir em virtude da adsorção desigual de íons com carga de sinal oposto e, assim é possível que a adsorção desses íons de cargas opostas na superfície inverta a carga elétrica da mesma (SHAW,1975)

$\mathrm{Na}$ Figura 107, são apresentados os valores de potencial zeta para a Rhodococcus opacus após os diferentes tempos de biossorção. Fez-se a leitura apenas em pH 2,6, já que esta foi a condição de trabalho empregada em todos os ensaios biossortivos. 


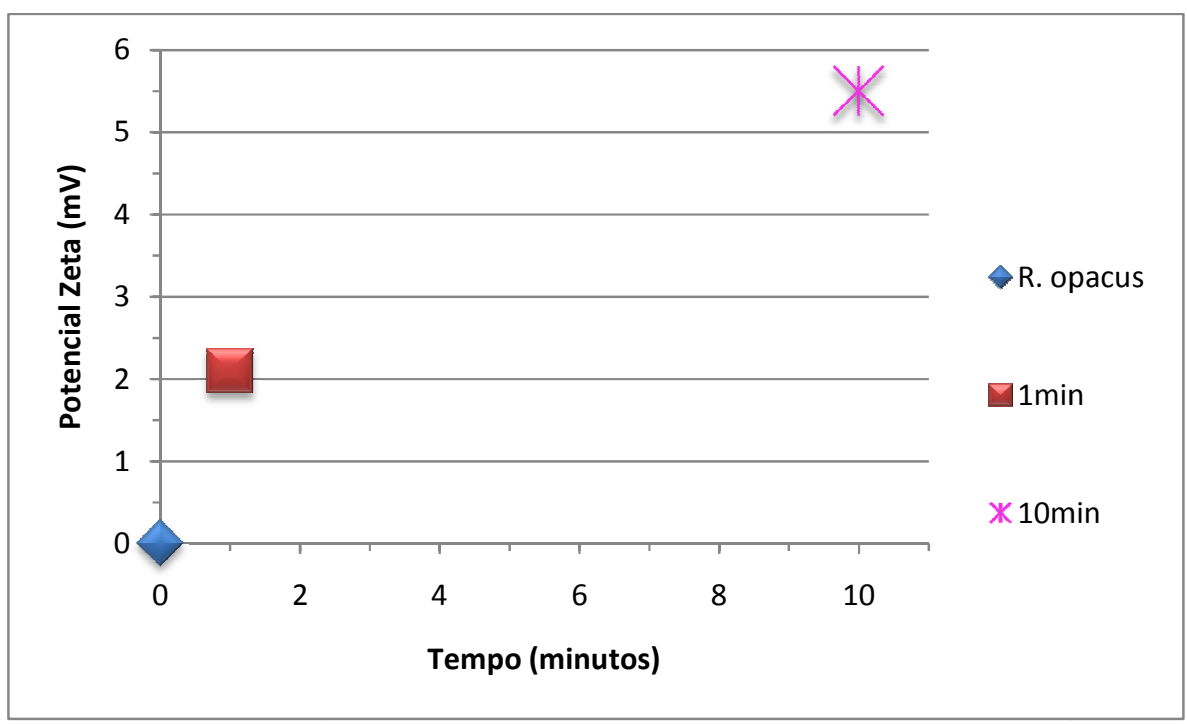

Figura 107 - Potencial zeta da biomassa após biossorção.

Como esperado, a biomassa apresentou valores positivos de potencial zeta, confirmando a interação entre os íons metálicos presentes na solução e os grupamentos presentes na superfície da célula bacteriana. Outros autores também chegaram a este mesmo resultado utilizando cepas de Rhodococcus opacus: Vásquez et al. (2007), Botero, Torem \& Mesquita (2008) e BUENO (2007).

É provável que o alto valor de pontecial zeta (em torno de 5,5mV) para a amostra que permaneceu em contato por $10 \mathrm{~min}$, esteja relacionado com o rompimento celular. 


\section{CONCLUSÕES}

Os resultados obtidos permitem concluir que:

- A porcentagem de metais presentes na composição elementar das células de Rhodococcus opacus obtida através do ensaio de perda ao fogo é, aproximadamente, $1,8 \%$.

- O processo biossortivo em sistema multimetálico atinge o equilíbrio em cerca de 1 minuto.

- Avaliando a remoção global, a captação máxima dos íons metálicos é $48,2 \mathrm{mg} \cdot \mathrm{g}^{-1}$. O que corresponde a aproximadamente $11,7 \%$ de remoção.

- Os metais que estavam em maior concentração foram os que tiveram maior captação: $\mathrm{Fe}->\mathrm{Ca}->\mathrm{Al}->\mathrm{Mg}$-> Mn $>\mathrm{Zn}$. Porém, proporcionalmente, o metal com maior captação foi o $\mathrm{Mn}$, seguido pelo $\mathrm{Fe}, \mathrm{Ca}, \mathrm{Al}, \mathrm{Zn}$ e $\mathrm{Mg}$.

- A transferência de massa parece não ser limitante no processo de adsorção dos íons metálicos pela biomassa, uma vez que nem a difusão externa, nem a difusão intraparticula são etapas dominantes do processo para nenhum dos metais estudados.

- O modelo cinético de pseudo-primeira ordem para sistemas monoelementares não se ajustou aos dados experimentais, tanto para a somatória, como para nenhum dos oito metais estudados em sistema multielementar.

- O modelo cinético de pseudo-segunda ordem para sistemas monoelementares, parece se ajustar adequadamente para o $\mathrm{Ca}$, Fe e $\mathrm{Mg}$ e também para a somatória dos metais, obteve-se coeficiente de correlação $\left(R^{2}\right)$ maior que 0,9 para essas condições.

- Imagens de elétrons secundários obtidas no microscópio eletrônico de varredura provou que há mudanças físicas na estrutura da biomassa após contato com a solução metálica.

- Nas analises de EDS não foi possível detectar todos os metais captados pela biomassa devido a natureza semi-quantitativa e não representativa do método, e também pela pequena massa de metais em solução (menor que $2,5 \mathrm{mg}$ ).

- Através dos espectros de FT-IR visualizou-se:

1) deslocamentos dos picos correspondentes aos seguintes grupos: $-\mathrm{OH},\left(-\mathrm{CH}_{3}\right),(-$ $\left.\mathrm{CH}_{2}\right),(\mathrm{R}-\mathrm{CO}) \mathrm{NH}_{2}$; 
2) incremento da banda correspondente aos seguintes grupos: $-\mathrm{NH}$ proveniente do estiramento assimétrico do grupo - $\mathrm{NH}_{2}$; e

3) surgimento de novas bandas referentes aos grupos: $-\mathrm{NH}$ proveniente do estiramento simétrico do grupo $-\mathrm{NH}_{2}$.

- Os resultados das medidas de potencial zeta mostraram que para a Rhodococcus opacus o PIE ocorre em pH próximo a 2,6; e também que há inversão nos valores de potencial zeta: antes neutros e, após os ensaios biossortivos, tornam-se positivos. 


\section{REFERÊNCIAS}

AKSU, Z. \& DONMEZ, G. Binary biosorption of cadmium(II) and nickel(II) onto dried Chlorella vulgaris: Co-ion effect on mono-component isotherm parameters. Process Biochemistry, v. 41, p. 860-868, 2006.

AMARAL, J. E.; KREBS, A. S. J. \& PAZZETTO, M. B. Bocas de Minas de Carvão abandonadas em Santa Catarina. In: XXIII Encontro Nacional de Tratamento de Minérios e Metalurgia Extrativa - Gramado, Rio Grande do Sul, 2009. Anais XXIII Encontro Nacional de Tratamento de Minérios e Metalurgia Extrativa. Rio Grande do Sul: 27 de setembro a 1ํ de outubro de 2009. v. 2, p. 397-402.

ALVAREZ, H. M. et al.. Physiological and morphological responses of the soil bacterium Rhodococcus opacus satrain PD360 to water tress. FEM Microbiology Ecology, v. 50, p. 75-86, 2004.

ASHKENAZY, R.; GOTTLIEB, L. \& YANNAI, S. Characterization of acetone-washed yeast biomass functional groups involved in lead biosorption. Biotechnology \& Bioengineering, v. 55, p. 1-10, 1997.

BELL, K. S., PHILIP, J. C., AW, D. W. J; CHRISTOFI, N. \& AW, D. J. W. Identification of Rhodococcus equi using the polymerase chain reaction. Letters in Applied Microbiology, v. 23, p.72-74, 1996.

BELL, K. S., PHILIP, J. C., AW, D. W. J \& CHRISTOFI, N. The genus Rhodococcus. Journal of Applied Microbiology., v. 85, p. 195-210, 1998.

BERNIER, L. R. The potential use of serpentine in the passive treatment of acid mine drainage: batch experiments. Environmental Geology, v. 47, p. 670-684, 2005.

BEVERIDGE, T. J. Interactions of gonococci with phagocytic cells. Annual review of microbiology, v. 43, p. 121-145, 1989.

BORBA, R. F. \& ARAÚJO, L. P. O. Carvão Mineral. Informe Mineral, Departamento Nacional de Produção Mineral - DNPM, p. 13, $1^{\circ}$ sem. 2009.

BORMA, L. de S. \& SOARES, P. S. M. Drenagem ácida e gestão de resíduos sólidos de mineração. In: TRINDADE, R. B. E. \& BARBOSA FILHO, O. Extração de ouro: princípios, tecnologia e meio ambiente. Rio de Janeiro: CETEM/MCT, 2002, cap. 10, p. 253-276.

BIRCH, L. \& BACHOFEN, R.. Complexing agents from microorganisms. Experientia, v. 46, p. 827-834, 1990. apud BUENO, B. Y. M. Remoção de Pb, Cr e Cu por processo combinado biossorção/bioflotação utilizando a cepa Rhodococcus opacus. 2007. 172 f. Tese (Doutorado) - Pontifícia Universidade Católica do Rio de Janeiro, Rio de Janeiro, 2007. 
BOTERO, A. E. C.; TOREM, L. M. \& de MESQUITA, L. M. S. Surface chemistry Fundamentals of biosorption of Rhodococcus opacus and its effect in calcite and magnesite flotation. Minerals Engineering, v. 21, p. 83-92, 2008.

BP Statistical Review of World Energy: june 2009. Disponível em: $<$ www.bp.com/worldenergy $>$. Acessado em: 24 fev 2010.

BUENO, B. Y. M. Remoção de $\mathrm{Pb}, \mathrm{Cr}$ e $\mathrm{Cu}$ por processo combinado biossorção/bioflotação utilizando a cepa Rhodococcus opacus. 2007. 172 f. Tese (Doutorado) - Pontifícia Universidade Católica do Rio de Janeiro, Rio de Janeiro, 2007.

CAMPANER, V. P. \& SILVA, W. L. Processos físico-quimicos em drenagem ácida de minas em mineração de carvão no sul do Brasil. Química Nova, v. 32, p. 146-152, 2009.

CÁNOVAS, M; GARCÍA-CASES, L. \& IBORRA, J. L. Shifts in metabolism and morphology of Rhodococcus fascians when debittering synthetic citrus juices in the absence of aeration. Biotechnology Letters, v. 19, n. 12, p. $1181-1184,1997$

CARRISSO, R. C. C. \& POSSA, M. V. Carvão mineral: aspectos gerais e econômicos. Rio de Janeiro: CETEM/CNPq, 1995. 30 p.

CAYLLAHUA, J. E. B. \& TOREM, M. L. Biosorption of nickel on Rhodococcus opacus from aqueous solution: determinations of equilibrium and kinetics parameters. In: International conference clean technologies for the world mining industry, 8th., 2008, Santiago. Anais International conference clean technologies for the world mining industry, $8^{\text {th }}$. Chile, 2008.

CEFALU, W. T. \& HU, F. B. Role of Chromium in human health and in diabetes. Diabetes Care, v. 27, p. 2741-2751, 2004.

CETEM. CENTRO DE TECNOLOGIA MINERAL. Projeto conceitual para recuperação ambiental da bacia carbonífera Sul Catarinense. RT 33/2000 (Relatório técnico elaborado para o Siecesc). Revisão 01. jan. 2001. v. 1. Disponível em: <http://siecesc.com.br/meio_ambiente/volume_001.pdf>. Acesso em: $30 \mathrm{mar}$. 2010.

CHANG, I. S.; SHIN, P. K. \& KIM, B. H.. Biological treatment of acid mine drainage under sulphate-reducing conditions with solid waste materials as substrate. Water Research, v. 34, p. 1269-1277, 2000.

CHARTRAND, M.M.G. \& BUNCE, N.J.. Electrochemical remediation of acid mine drainage. Journal of Applied Electrochemistry, v. 33, p. 259-264, 2003.

CHAVES, A. P. Flotação de carvão de Santa Catarina (região do alto metalúrgico). 1982. 142 f. Tese (Doutorado) - Escola Politécnica da Universidade de São Paulo, São Paulo, 1982. 
CHAVES, A. P. Estrutura e comportamento dos carvões. 1972.104 f. Dissertação (mestrado) - Escola Politécnica da Universidade de São Paulo, São Paulo, 1972.

CHEUNG, H. \& GU, J. D. Reduction of chromate by na enrichment consortium and an isolate of marine sulfate-reducing bacteria. Chemosphere, v. 52, p. 1523-1529, 2003.

CHOJNACKA, K. Biosorption and bioaccumulation - the prospects for pratical applications. Environment International, v. 36, p. 299-307, 2010.

CHOJNACKA, K.; CHOJNACKI, A. \& GÓRECKA, H. Biosorption of Cr3+, Cd2+ and Cu2+ ions by blue-green algae Spirulina sp.: kinetics, equilibrium and the mechanism of the process. Chemosphere, v. 59, p. 75-84, 2005.

RESOLUÇÃO CONAMA, Conselho Nacional do Meio Ambiente - CONAMA, Resolução $\mathbf{n}^{\circ}$ 357, de 17 de março de 2005. Ministério do Meio Ambiente, Brasília. 2005.

COSTA, M. C.; SANTOS, E. S.; BARROS, R. J.; PIRES, C. \& MARTINS, M. Wine wastes as carbon source for biological treatment of acid mine drainage. Chemosphere, v. 75, p. 831-836, 2009.

CUI, J. \& ZHANG, L. Metallurgical recovery of metals from electronic waste: a review. Journal of Hazardous Materials, v. 158, p. 228-256, 2008.

DAVIS, T. A.; VOLESKY, B. \& MUCCI, A. A review of heavy metal biosorption by brown algae. Water Research, v. 37, p. 4311-1330, 2003.

ELLIOTT, P.; RAGUSA, S. \& CATCHESIDE, D.. Growth of sulfate-reducing bacteria under acidic conditions in an upflow anaerobic bioreactor as a treatment system for acid mine drainage. Water Research, v. 32, p. 3724-3730, 1998.

ERDEM, E.; KARAPINAR, N. \& DONAT, R.. The removal of heavy metal cations by natural zeolites. Journal of Colloid and Interface Science, v. 280, p. 309-314, 2004.

FARFAN, J. R. J. Z.; BARBOSA FILHO, O. \& de SOUZA, V. P. Avaliação do potencial de drenagem ácida de rejeitos da indústria mineral. Rio de janeiro: CETEM/MCT, 2004. 58p.

FEBRIANTO, J. et al. Equilibrium and kinetic studies in adsorption of heavy metals using biosorbent: a summary of recent studies. Journal of Hazardous Materials, v. 162, p. 616-645, 2009.

FENG, D.; ALDRICH, C. \& TAN, H.. Treatment of acid mine water by use of heavy metal precipitation and ion exchange. Minerals Engineering, v. 13, p. 623-642, 2000. 
FERGUSON, K. D. \& ERICKSON, P. M. Pre-Mine prediction of acid mine drainage. In: SALOMONS W. \& FORSTNER, U. Dredged Material and Mine Tailings. Berlin: Springer-Verlag, 1988. apud U. S. Environmental Protection Agency - EPA. Acid mine Drainage prediction (technical document).Washington, 1994, cap. 1, p. 1-8.

FINNERTY, W. R. The biology and genetics of the genus Rhodococcus. Annual Review of Microbiology, v. 46, p. 193-218, 1992.

FOSMIRE, G. J. Zinc toxicity. American Journal of Clinical Nutrition, v. 51, p. 225-227, 1990.

GAIKWAD, R. W. \& GUPTA, D.V. Review on removal of heavy metals from acid mine drainage. Applied Ecology and Environmental Research, v. 6, p. 81-98, 2008.

GAO, Y. L.; ARUP, K.. S.\& SIMPSON, D. A new hybrid inorganic sorbent for heavy metals removal. Water Research, v. 29, p. 2195-2205, 1995.

GARCIA Jr, O. Utilização de Microrganismos em Processos Bio-hidrometalúrgicos. In: I \& II Encontros de Metalurgia, Mineração e Materiais da UFMG. Belo Horizonte, 1995. Anais I \& II Encontros de Metalurgia, Mineração e Materiais da UFMG. Belo Horizonte, 1995.

GOMES, A. J. P. Carvão do Brasil Turfa Agrícola: geologia, meio ambiente e participação estratégica na produção de eletricidade no sul do Brasil. Porto Alegre: EST, 2002. 164 p.

GOMES, C.J. B. Projeto para Recuperação Ambiental da Bacia Carbonífera Sul Catarinense: Relatório de Atividades - Fevereiro de 2004.

GOODFELLOW, M.; ALDERSON, G. \& CHUN, J. Rhodococcal systematics: problems and developments. Antonie van Leeuwenhoek, v. 74, p. 3-20, 1998.

GREENE, B.; MCPHERSON, R.; \& DARNALL, D. Algal sorbents for selective metal ion recovery, in metals speciation, separation and recovery. In: PATTERSON, J. W. \& PASINO, R. Metals speciation, separation, and recovery. Chelsea: Lewis, 1987, p. 315-338.

GUIBAL, E., MILOT, C., TOBIN, M. J. Metal-anion sorption by chitosan beads: equilibrium and kinetic studies. Industrial and Engineering Chemistry Research, v. 37, p. 1454-1563, 1998.

GYLES, C. L.; PRESCOTT, J. F.; SONGER, J. G. \& THOEN, C. O. (ed.): Pathogenesis of Bacterial Infections in Animals. Lowa: Blackwell Publishing Professional, 2004. 456p.

HAYASHI, A. M. Remoção de Cromo hexavalente através de processos de biossorção em algas marinhas. 2001. 209 f. Tese (Doutorado) - Faculdade de Engenharia Química - UNICAMP, Campinas, 2001. 
JENKE, D. R. \& DIEBOLD, F. E. Recovery of valuable metals from acid mine drainage by selective titration. Water Research, v. 17, n. 11, p. 1585-1590, 1983.

JIRGENSONS, B \& STARAUMANIS, M. E. Interfacial phenomena - The rules and forces of adsorption. In: Macmillan, 1962. p. 102-105. A short textbook of colloid chemistry. New York:

KANE, A. B. \& KUMAR, V. Patologia nutricional e ambiental. In: Patologia - bases patológicas das doenças. $7^{\circ}$ ed. Rio de Janeiro: Elsevier, 2005. Cap. 9, p. 433-490.

KAPOOR, A. \& VIRARAGHAVAN, T. Biosorption - an alternative treatment option for heavy metal bearning wastewaters: a review. Bioresource Technology, v. 53, p. 195-206, 1995.

KAPOOR, A. \& VIRARAGHAVAN, T. Heavy metals biosorption sites in Aspergillus niger. Bioresource Technology, v. 61, p. 221-227, 1997.

KONTOPOULOS, A. Acid Mine Drainage Control. In: CASTRO, S. H.; VERGARA, F. \& SÁNCHEZ, M. A.; Effluent Treatment in the Mining Industry. Chile: University of Concepción, 1998, p. 57-118.

KOPPE, J. C. \& COSTA, J. F. C. L. A lavra de carvão e o meio ambiente em Santa Catarina. In: SOARES, P. S. M.; dos SANTOS, M. D. C. \& POSSA, M. V. Carvão Brasileiro: tecnologia e meio ambiente. Rio de Janeiro: CETEM/MCT, 2008. p. 2535.

KRATOCHVIL, D. \& VOLESKY, B.. Advances in biosorption of heavy metals. Trends in Biotechnology, v. 16, p. 291-300, 1998.

KURNIAWAN, T. A. et al. Physico-chemical treatment techniques for wastewater laden with heavy metals. Chemical Engineering Journal, p. 83-98, 2006.

KYAW, C. M. Morfologia e Estruturas bacterianas - parte 1. Disponível em: $<$ http://vsites.unb.br/ib/cel/microbiologia/morfologia1/morfologia1.html>. Acesso em: 23 de fev. de 2010.

LA, H.; KIM, K.; QUAN, Z.; CHO, Y. \& LEE, S. Enhancement of sulfate reduction activity using granular sludge in anaerobic treatment of acid mine drainage. Biotechnology Letters, v. 25, p. 503-508, 2003.

LEMOS, J. L. S. Revisão acerca da utilização de microrganismos na biorremediação de rejeitos insdustriais contendo metais pesados. Série Tecnologia Ambiental, v. 43. CETEM/MCT. Rio de Janeiro, 2008. 65p.

LEWIS, M. E. \& CLARK, M. L. How does stream flow affect metals in the upper Arkansas river? US Geological Survey Fact Sheet, p. 226-296, 1996.

LIU, Y. \& LIU, Y. Biosorption isotherms, kinetics and thermodynamics. Separation and Purification Technology, v. 61, p. 229-242, 2002. 
LOPES, R. P.; SANTO, E. L. \& GALATTO, S. L. Mineração de carvão em Santa Catarina: geologia, geoquímica e impactos ambientais. In: MILIOLI, G.; dos SANTOS, R. \& CITADINI-ZANETTE, V. Mineração de carvão, meio ambiente e desenvolvimento sustentável no sul de Santa Catarina. Curitiba: Juruá, 2009. p. $51-70$.

de LUCA, F. J. Aplicação da metodologia sistêmica de avaliação: o setor da mineração no sul do estado de Santa Catarina - Cadeia de impactos ambientais na mineração. In: _ Modelo cluster eco-industrial de desenvolvimento. Rio de Janeiro: Papel e Virtual, 2003 . p- 251-254.

MACHADO, J. L. F.; PERUFO, N. \& LIMA, J. E. S. Programa nacional de prospecção para carvão, linhito e turfa: projeto estudo da vulnerabilidade à contaminação dos mananciais subterrâneos decorrente da extração do carvão mineral. Brasília: Ministério das Minas e Energia/Departamento Nacional da Produção Mineral/Convênio DNPM/CPRM, 1984. p. 67-77, 1984. cap. 8, v. 1 (Relatório final fase I). apud LOPES, R. P.; SANTO, E. L. \& GALATTO, S. L. Mineração de carvão em Santa Catarina: geologia, geoquímica e impactos ambientais. In: MILIOLI, G.; dos SANTOS, R. \& CITADINI-ZANETTE, V. Mineração de carvão, meio ambiente e desenvolvimento sustentável no sul de Santa Catarina. Curitiba: Juruá Editora, 2009. p. 51-70.

MACHADO, L. A. Ensaios estatísticos e cinéticos para prevenção da geração de drenagem ácida de minas na mineração de carvão com cinzas termoelétricas e escória de aciaria. Dissertação (Mestrado) - Universidade Federal do Rio Grande do Sul, Porto Alegre, 2007.

MATLOCK, M. M.; HOWERTON, B. S. \& ATWOOD, D. A. Chemical precipitation of heavy metals from acid mine drainage. Water Research, v. 36, p. 4757-4764, 2002.

MAYERS, L.T. e BEVERIDGE, T. J. The sorption of metals to Bacillus subtilis walls from dilute solutions and simulated Hamilton harbour (Lake Ontario) water. Journal of Microbiology, 35, 764-770, 1989.

MESQUITA, L. M. S. Bioflotação de hematita e quartzo - um estudo de seletividade. 2000. Tese (Doutorado) - Pontifícia Universidade Católica do Rio de Janeiro, Rio de Janeiro, 2000 apud BUENO, B. Y. M. Remoção de Pb, Cr e Cu por processo combinado biossorção/bioflotação utilizando a cepa Rhodococcus opacus. 2007. 172 f. Tese (Doutorado) - Pontifícia Universidade Católica do Rio de Janeiro, Rio de Janeiro, 2007.

MESQUITA, L.M.S., LINS F.F.; TOREM M.L. Interaction of a hydrophobic bacterium strain in a hematite-quartz flotation System. International Journal of Mineral Processing, v. 71, p. 31- 44, 2003.

MIRIMANOFF, N. \& WILKINSON, K. J. Regulation of $\mathrm{Zn}$ accumulation by a freshwater gram-positive bacterium (Rhodococcus opacus). Environ. Sci. Technolo, v. 34, p. 616-622, 2000. 
MOZES, N.; AMORY, D.; LÉONARD, A. \& ROUXCET, P. Surface Properties of Microbial Cells and their Role in Adhesion and Flocculation. Colloids and Surfaces, v. 42, p. 313-329, 1989.

NETO, R. R., SANTOS DOS, E. F., IZIDORO, G., VIEIRA, P. C., SCHNEIDER, I. A. H. Utilização do Lodo de uma Estação de Tratamento de Drenagens Ácida de Minas em Materiais Cerâmicos. In: XXI ENTMME - Natal-RN, novembro de 2005. Anais... Rio Grande do Norte, 2005.

NEVES, C. A. R. \& SILVA, L. R. Universo da Mineração Brasileira. Departamento Nacional de Produção Mineral - DNPM, Brasília, 2007.

"ORLANDI FILHO, V.; KREBS, A. S. J. \& GIFFONI, L. E. Excursão virtual pela serra do rio do rastro. CPRM - Companhia de Pesquisa de Recursos Minerais: Serviço Geológico do Brasil, 2002. Disponível em: $<$ http://www.cprm.gov.br/coluna/carvaomineral0.html >. Acesso em: 23 de fev. de 2010.

OSCIK, J. Adsorption. New York: Halsted Press, 1982. 206 p. apud BUENO, B. Y. $\mathrm{M}$. Remoção de $\mathrm{Pb}, \mathrm{Cr}$ e $\mathrm{Cu}$ por processo combinado biossorção/bioflotação utilizando a cepa Rhodococcus opacus. 2007. 172 f. Tese (Doutorado) - Pontifícia Universidade Católica do Rio de Janeiro, Rio de Janeiro, 2007.

PAGNANELLIA, F.; ESPOSITOB, A.; TOROA, L. \& VERGLIÖB, F. Metal speciation and $\mathrm{pH}$ effect on $\mathrm{Pb}, \mathrm{Cu}, \mathrm{Zn}$ and $\mathrm{Cd}$ biosorption onto Sphaerotilus natans: Langmuirtype empirical model. Water Research, v. 37, p. 627-633, 2003.

PINO, G. A. H.. Biossorção de metais pesados em pó de casca de coco (Cocos nucífera). 2005. 101f. Dissertação (Mestrado) - Universidade Federal do Rio de Janeiro, Rio de Janeiro, 2005.

POSSA, M. M. \& dos SANTOS, M. D. C. Tratamento de drenagem ácida de mina por processo de neutralização controlada. Rio de Janeiro, 2003. Contribuição técnica elaborada para o Seminário Brasil-Canadá de recuperação ambiental de áreas mineradas. Florianópolis, dezembro de 2003, v.1. p. 233-252.

RAO, S.R. Recycling Metal. In: RAO, S.R. (Editor) Resources Recovery and Recycling from Metallurgical Wastes. Waste Management Series, v. 7. Netherland: Elsevier, 2006, p. 509-545.

RADHIKA, V.; SUBRAMANIAN, S. \& NATARAJAN, K. A. Bioremediation of zinc using Desulfotomaculum nigrificans: bioprecipitation and characterization studies. Water Research, v. 40, p. 3628-3636, 2006.

RIJNAARTS, H. M.; NORDE, W.; LYKLEMA, J. \& ZEHNDER, A. The isoeletric point of bacteria as na indicator for the presence of cell surface polymers thet inhibit adhesion. Colloids and Surfaces B: Biointerfaces, v. 4, p. 191-197, 1995 
RODRIGUES, A. F. S. Aerogeofísica no Brasil - Descobrindo a geodiversidade encoberta. Informe Mineral, Departamento Nacional de Produção Mineral - DNPM, p. 29-45, $1^{\circ}$ sem. 2009.

ROSE, P.D.; BOSHOFF, G.A.; VAN HILLE, R.P.; WALLACE, L.C.M.; DUNN, K.M. \& DUNCAN, J.R. An integrated algal sulphate reducing high rate ponding process for the treatment of acid mine drainage wastewaters. Biodegradation, v. 9, p. 247-257, 1998.

ROSE, S. \& GHASZI, A. M. Experimental study of the stability of metals associated whit iron oxyhydroxides precipitaded in acid mine drainage. Environmental Geology, v. 36. p. 364-370, 1998.

SARI, A. \& TUZEN, M. Equilibrium, thermodynamic and kinetic studies on aluminun biosorption from aqueous solution by brown algae (Padina pavonica) biomass. Journal of Hazardous Materials, v. 171, p. 973-979, 2009.

SCHNEIDER, I. A. H. Biossorção de metais pesados com a biomassa de macrófilos aquáticos. 1995. 120 f. Tese (Doutorado) - Universidade Federal do Rio Grande do Sul, Porto Alegre, 1995.

SCHNEIDER, C. H. Controle da drenagem ácida de minas na mineração de carvão de Santa Catarina: caso da mina UM II Verdinho.2006. Dissertação (Mestrado) - Universidade Federal do Rio Grande do Sul, Porto Alegre, 2006.

SCHNEIDER, C. H. Evolução da gestão ambiental na indústria carbonífera em Santa Catarina: um caso de sucesso. In: SOARES, P. S. M.; dos SANTOS, M. D. C. \& POSSA, M. V. Carvão Brasileiro: tecnologia e meio ambiente. Rio de Janeiro: CETEM/MCT, 2008. p. 39-56.

SELATNIA, A.; BOUKAZOULA, A.; KECHID, N.; BAKHTI, M. Z.; CHERGUI, A. \& $\mathrm{KERCHICH}$, Y. Biosorption of lead (II) from aqueous solution by a bacterial dead Streptomyces rimosus biomass. Biochemitry Engineering Journal, v. 19, p. 127135, 2004.

SHARMA , P. K. Surface studies relevant to microbial adhesion and bioflotation of sulphide minerals. Thesis (doctoral) - Lulea University of Technology, Sweden,. 2001 apud BOTERO, A. E. C.; TOREM, L. M. \& de MESQUITA, L. M. S. Surface chemistry Fundamentals of biosorption of Rhodococcus opacus and its effect in calcite and magnesite flotation. Minerals Engineering, v. 21, p. 83-92, 2008.

SHAW, D. J. Interfaces com cargas elétricas. In: _. Introdução à química dos colóides e de surperfícies. Tradução de MAAR, J. H.. São Paulo: Edgard Blücher, 1975, p. 102-127.

SHOKROLLAHI, A.; GHAEDI, M.; NIBAND, M.S. \& RAJABI, H.R. Selective and sensitive spectrophotometric method for determination of submicro-molar amounts of aluminum ion. Journal of Hazardous Materials, v. 151, p. 642-648, 2008. 
SIECESC - Sindicato da Indústria de Extração de Carvão do Estado de Santa Catarina. Histórico do Carvão em Santa Catarina, 2010. Disponível em: <http://www.siecesc.com.br> Acesso em: 23 de fev. de 2010.

SINGER, P. C. \& STUMM, W. W. Acid mine drainage: the rate determining step. Science, v. 167, p. 1121-1123, 1970.

STACKEBRANDT, E.; RAINEY, F.A. \& WARD-RAINEY, N.L. Proposal for a new hierarchic classification system. International Journal of Systematic Bacteriology, v. 47, p. 479-491, 1997.

STRATTON, H.; BROOKS,P.; SERVIOUR, R.. Cell surface hydrofobicity and mycolic acid composítion of Rhodococcus strains isolated from activaded sludge foam. Journal of Industrial Microbiology an Biotechnology, v. 28, p. 264 - 267, 2002.

STROBEL, B. W.; HANSEN, H. C. B.; BORGGAARD, O. K.; ANDERSEN, M. K. \& RAULUND-RASMUSSEN, K. Cadmium and cooper release kinetics in relation to afforestation of cultivated soil. Geochimica et Cosmochimica Acta, v. 65, p. 12331242, 2001.

TOBIN, J. M.; WHITE, C.; GADD, G. M. Metal Accumulation by Fungi. Applications Journal of Industrial Microbiology, v.13, p. 126-130, 1994.

TOSATTO, P. Carvão Mineral. In: Geodiversidade do Brasil: a construção das geociencias. Departamento Nacional de Produção Mineral - DNPM. Brasilia, 2005.

TSUKAMOTO, T. K.; KILLION, H. A. \& MILLER, G. C. Column experiments for microbiological treatment of acid mine drainage: low-temperature, low-pH and matrix investigations. Water Research, v. 38, p. 1405-1418, 2004.

UMITA, T. Biological mine drainage treatment. Resources, Conservation and Recycling, v. 16, p. 179-188, 1996.

UTGIKAR, V.; CHENA, B.; TABAKA, H. H.; BISHOPA, D. F. \& GOVIND, R.. Treatment of acid mine drainage: I. Equilibrium biosorption of zinc and copper on non-viable activated sludge. International Biodeterioration \& Biodegradation,v. 46, p.19-28, 2000.

VAN der WAL, A.; NORDE, A.; ZEHNDER, A. J. B. \& LYKLEMA, J. A determination of the total charge in the cell walls of gram-positive bacteria. Colloids and surfaces B: Biointerfaces, v. 9, p. 81-100, 1997.

VÁSQUEZ, T. G. P. Avaliação da remoção de $\mathrm{Cd}$ e $\mathrm{Zn}$ de solução aquosa por biossorção e bioflotação com Rhodococcus opacus. 2005. 108 f. Dissertação (Mestrado) - Pontifícia Universidade Católica do Rio de Janeiro, Rio de Janeiro, 2005.

VÁSQUEZ, T. G. P.; BOTERO, A. E. C.; de MESQUITA, L. M. S. \& TOREM, M. L. Biosorptive removal of $\mathrm{Cd}$ and $\mathrm{Zn}$ from liquid streams with a Rhodococcus opacus strain. Minerals Engineering, v. 20, p. 939-944, 2007. 
VAZ, P. A. B. Reparação do dano ambiental - Caso concreto: mineração em Santa Catarina e o meio ambiente. Revista CEJ, n. 22, p. 41-48, jul./set. 2003

VEGLIÓ F. \& BEOLCHINI, F.. Removal of metals by biosorption- a review. Hydrometallurgy, v. 44, p. 301-316, 1997.

VIANA, L. R. Identificação fenotípica e molecular de rhodococcus equi e dietzia maris em bubalinos. 2007. Dissertação (Mestrado) - Universidade Federal de Santa Maria, Rio Grande do Sul, 2007.

VOLESKY, B. Biosorbents for recovery of metals from industrial solutions. Biotecnology Letters, v. 10, n. 2, p. 135 - 149, 1988.

VOLESKY, B. Biosorption of Heavy Metals. Florida: CRC Press, 1990. 408 p.

VOLESKY, B. Equilibrium biosorption performance. In: Sorption and Biosorption. Montreal: BV Sorbex, 2003, p. 103-116.

VOLESKY, B. Biosorption and me. Water Research, v. 41, p. 4017-4029, 2007.

VOLESKY, B. \& HOLAN, Z.R. Biosorption of heavy metals. Biotechnology Progress, v. 11, p. 235-250, 1995

WALSH, C. T.; SANDSTEAS, H. H.; PRASAR, A. S.; NEWBERNE, P. M. \& FRAKER, P. J. Zinc: health effects and research priorities from the 1990's. Environmental Health Perspectives, v. 102, p. 5-46, 1994.

WANG, X. \& QUIN, Y. Equilibrium sorption isotherms for of Cu2+ on rice bran. Process Biochemistry, v. 40, p. 677-680, 2005.

WEI, X.; VIADERO Jr, R. C. \& BUZBY, K. M.. Recovery of iron and aluminum from acid mine drainage by selective precipitation. Environmental Engineering Science, v. 22, p. 745-755, 2005.

WEI, X; VIADERO Jr., R.C. \& BHOJAPPA, S. Phosporus removal by acid mine drainage sludge from secondary effluents of municipal wastewater treatment plants. Water Research, v. 42, p. 3275-3284, 2008.

WESTALL, J. C. Adsorption mechanisms in aquatic surface chemistry. New York: John Wiley ans Sons, 1987, p. 3-32.

WHITE, C.; WILKINSONAND, S. C.; GADD, G.M.. The role of microorganisms in biosorption of toxic metals and radionuclides. International Biodeterioration \& Biodegradation, Londres, v. 35, n. 1-3, p.17-40, 1995.

WORLD COAL INSTITUTE. What is coal?. Disponével em: $<$ http://www.worldcoal.org>. Acesso em 23 de fev. de 2010. 
XIE, J. Z.; CHANG, H. \& KILBANE, J.J.. Removal and recovery of metal ions from wastewater using biosorbents and chemically modified biosorbents. Bioresource Technology, v. 57, p. 127-136, 1996.

ZAGURY, G. J.; KULNIEKS, V. I. \& NECULITA, C. M.. Characterization and reactivity assessment of organic substrates for sulphate-reducing bacteria in acid mine drainage treatment. Chemosphere, v. 64, p. 944-954, 2006.

ZOUBOULIS, A. I.; LOUKIDOU, M.X. \& MATIS, K.A. Biosorption of toxic metals from aqueous solutions by bacteria strains isolated from metal-polluted soils. Process Biochemistry, v. 39, p. 909-916, 2004. 